5

$$
\text { (1) }
$$




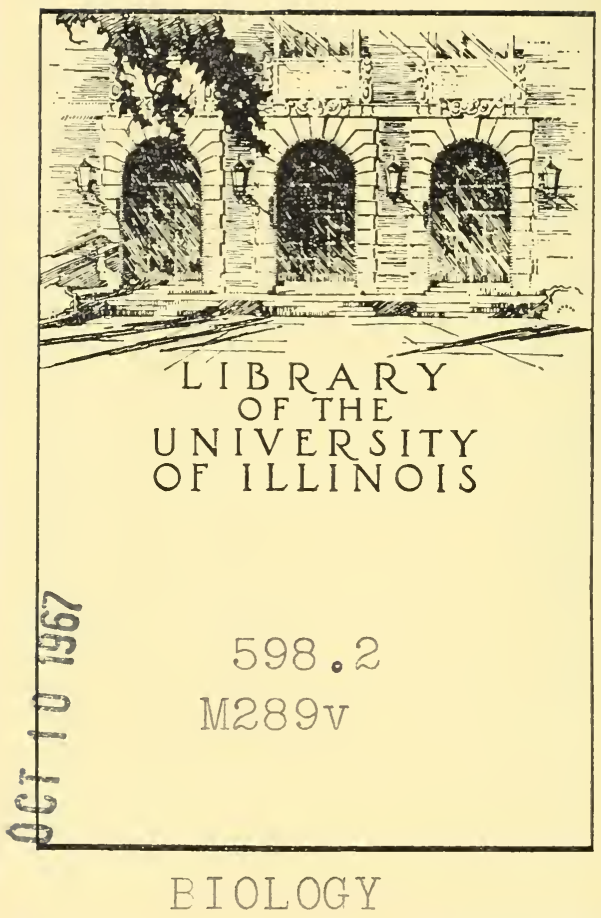


Digitized by the Internet Archive in 2011 with funding from University of Illinois Urbana-Champaign 



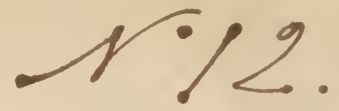

Vetenskapliga grumder för bestämmmandet af

\title{
fogelarternas ordningsföljd
}

\section{inom slägten och grupper.}

\author{
Akademisk afhandling,
}

lıvilken med den vidtberömda Filosofiska Fakultetens vid Kejserliga Alexanders-Universitetet begifvande,

till offentlig granskning framställes

af

\section{D:r F. W. Mäklin,}

e. o. professor i zoologi,

i filosofiska lärosalen den 27 April 1867

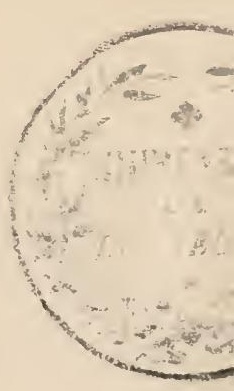

p. v. t. f. m.

Ilelsingfors,

J. C. Frenckell \& Son, 1867.

R. FRIEDLANDER \& SOIIN Buchhandlung Berlin N.W. 6 . 11. Carlstrasse 11. 



\section{$5 \%, 2$ M 281 V}

Ett till alla delar fullständigt och tillika fullkomligen naturligt system i zoologin måste anses som ett slutresultat, hvartill denna retenskap sträfvar, ty detta mål kan naturligtvis uppnås först då, när man vunnit en säker kännedom om samtliga djurformer och deras organiska byggnad. Då den retenskapliga framställningens form emellertid är den systematiska och systematiken således äfren under den zoologiska vetenskapens fortgående utreckling måste anses som grundvalen för densamma, skall man utan tvifvel framdeles liksom hittills, i den mån den vetenskapliga forskningen framskrider, efterhand sammanställa de redan vunna resultaterna, för att med ledning af desamma på ett allt mera naturenligt sätt gruppera och ordna de kända formerna och sålunda småningom närma sig det eftersträfvade målet. Som en allmän princip har den åsigten gjort sig gällande, att djurarterna böra ordnas i systemet efter den olika utrecklingsgraden af deras organer, då man ställer antingen de fullkomligast organiserade främst och slutar med de minst utbildade eller trärtom. Man föreställde sig en tid, att samtliga arter i djurriket bildade en enda fortgående serie ifrån de lägsta till de högsta; men redan länge har man insett, att detta ingalunda är fallet, utan att denna utvecklings serie sträcker sig i flere skilda riktningar. I händelse man nemligen vill åskådliggöra den successiva utvecklingen inom djurriket medelst en bild, kan densamma ej förliknas med en linie, utan, såsom man i sednare tider ganska lämpligt gjort, med ett träd och dess förgreningar, då de ifrån stammen utgående hufvudgrenarna motsvara klasser och de sekundära och följande förgreningarna i sin tur ordningar, familjer, slägten ät-

(F. W. M-n V. 1867.) 
vensom arter. Ty liksom pâ ett träd flere quistar, hvilka utgå från stammens öfre grenar, i sjelfva verket kunna hänga lägre ner och icke komma till samma grad af utveckling (bära blommor o. s. v.), som flere andra, hvilka leda sitt ursprung från nedanföre belägna grenar, så är det äfven fallet inom djurriket, att de lägsta formerna inom en grupp, hvilken på grund af de flesta eller åtminstone de mest utbildade representanternas organisation ställes mycket högre, onekligen stå på en lägre utvecklings ståndpunkt, än de mest utbildade inom en lägre afdelning. Vid den systematiska sammanställningen af hela djurriket, måste således i öfverensstämmelse härmed icke allenast hufvudgrupperna (klasser, ordningar, familjer o. s. v.) ordnas efter organernas relativa utveckling, utan äfven t. o. m. de skilda arterna inom hvarje genus.

Att systematiseringen af djurriket under sednaste decennier gjort betydliga framsteg, är allmänt bekant, och skulle man med någon fullständighet söka att framhålla den mångsidiga utveckling den zoologiska vetenskapen vunnit äfven i denna riktning, kunde en framställning härom, äfven med förbigånde af den otaliga mängd species, som isynnerhet genom mer eller mindre omfattande monografiska arbeten blifvit närmare kända och hvilka härvid utgöra det nödvändiga materialet, onekligen fylla volymer. För att endast med några ord här antyda đet som $\mathrm{i}$ ifrågavarande afseende på sednare tider blifvit gjordt och enligt vår öfvertygelse närmast förestår att göras, tro vi oss, med begagnande af den ofvanföre framhållna liknelsen, i öfverensstämmelse med verkliga förhållandet kunna påstå, att man med afseende på djurarternas systematisering både på grund af deras organiska byggnad äfvensom med ledning af hela deras utveckling ända ifrån primitiv-ägget hufvudsakligen sökt att bestämma, till hvilka förgreningar af stammen hvarje särskild form bör hänföras samt tillika fullständigare bestämt antalet af och noggrannare utstakat gränserna för dessa förgreningar. Man har derjemte och 
öfverhufvudtaget med stöd af vetenskapliga grunder med större eller mindre framgång inom skilda afdelningar försökt att bestämma hufvudgrenarnes högre eller lägre plats uppå sjelfva stammen; men såvidt det beträffar de sekundära och isynnerhet de sista förgreningarna, d. v. s. slägten och arter, har man i allmänhet icke ens försökt att efter någon slags förnuftig princip afgöra deras inbördes företräde, utan har deras plats nästan uteslutande blifvit bestämd af enskilde naturforskares subjektiva godtycke. Detta påstående, att icke allenast arterna och genera, utan äfven familjer, om ej ännu större afdelningar, ännu i närvarande stund ordnas i zoologin utan något fästadt afseende vid organernas lägre eller högre utvecklingsgrad, gäller föröfrigt ingalunda blott om de lägre djurformerna, utan t. o. m. om de mest utbildade bland de vetebrerade djuren. Det kan visserligen ej förnekas, att $i$ spetsen för hvarje grupp eller slägte merendels ställes någon oftust endast genom sin storlek mera framstående art och till sist t. ex. någon särdeles i ögonen fallande degraderad form, men denna omständighet kan väl knappast anses såsom ett bevis emot vårt här ofvanföre anförda påstående, då alla mellanliggande generiska eller artformer inrangeras i systemet nära nog efter det fullkomligaste godtycke. Följderna af ett sådant förfuringssätt i den systematiska delen af den zoologiska vetenskapen måste af hvar och en på förhand kunna beräknas, ty de äro sjelffallna, nemligen att de former, som af en naturforskare uppföras främst, af andra ofta nog ställas emot slutet eller t. o. m. sist inom en serie. Att detta på mångahanda sätt och kanske isynnerhet för den systematiska uppställningen af zoologiska samlingar särdeles störande förhållande skall fortfara, ända tills man på ett förnuftsenligt sätt bestämmer formernas relativa plats inom hvarje hufvudgrupp, är utom allt tvifvel, då man föga kan hoppas, att åsigter, som endast motiveras af godtycke, någonsin till alla delar kunna öfverensstämma med hvarandra; och kan detta så mycket min- 
dre vara fallet inom retenskapernas område, der livarje godtycke måste vara banulyst och endast en förnuftig princip kan vinna allmän giltighet. För vår del tro vi dock, att man redan vid zoologins närvarande ståndpunkt inom de flesta, om ej inom alla djurgrupper bör åtminstone approximativt kunua ordna de skilda art- och generiska formerna äfrensom större afdelningar efter den relativa utvecklingsgraden af deras organer, endast man inser nödvändigheten häraf och vill rikta sin uppmärksamhet och sina forskningar åt detta håll.

För att $\mathrm{i}$ allmänhet visa, huru man enligt vår åsigt bör gå tillväga vid bedömmandet af enskilda slägtens och arters företräde framför andra i systemet, hafva vi här förelagt oss att utforska de allmänna vetenskapliga grunder, med hvilkas ledning man enligt vår öfvertygelse bör kunna bestämma foglarnas relativa ställning inom de skilda hufvudgrupperna, och hoppas vi att härigenom åtminstone visa möjligheten att frigöra sig från det fullkomliga godtycke, som i detta afseende hittills varit rådande.

Då emellertid mången, son förut icke närmare fästat sin uppmärksambet vid dessa här öfverklagade bristfälligheter inom systematikens område, möjligen betviflar, att ett sådant godtycke $\mathrm{i}$ sjelfva verket varit och är rådande isynnerhet i den systematiska ordningsföljden bland representanterna af en djurklass, hvilken med en så stor förkärlek blifvit bearbetad som foglarnas, anse vi det nödvändigt att här ur några mera framstående arbeten eller hos oss allmännare kända och begagnade handböcker framhålla några exempel, hvilka synas vara egnade att på ett öfvertygande sätt i̊dagalägga sanningen af våra här anförda påståenden.

I Svenska foglarna ställer Sundevall inom ordningen Passeres och den underafdelning deraf, som allmänt är känd under benämningen af Oscines, främst de finkartade foglarna eller de s. k. Fringilliformes samt derefter i 
ordning Turdiformes, Scansores (Genera Sitta och Certhia), Hirundiniformes, Corviformes och Tubilingues. - I Museum ornithologicum Heineanum har CABANIS deremot, om vi fästa oss endast vid de i Skandinavien och Finland förekommande arterna, uppräknat de former, som höra till ofvanstånde grupper, sålunda, att en del af Turdiformes ställas främst, derefter Hirundiniformes, sedan de återstående af Turdiformes (likväl med undantag af slägtet Oriolus, som föres till familjen Paradiseidae och således till Sunderall's Corviformes) samt slutligen Scansores, Fringilliformes och Corviformes. Tubilingues, hvilka icke representeras af några former i Europa och således icke heller i den skandinaviska norden, uppställas af CaBaris emellan Scansores och Fringilliformes - Uteslutas de slägten, hvilka numera allmänt föras till andra ordningar inom foglarnas klass, finner man, att ordningsföljden af de ofvanuppräknade till Oscines hörande grupperna i Skandinavisk fauna af Nilsson (3:dje uppl.) är följande: Scansores, Corviformes, en del af Turdiformes (Genera Oriolus och Bombycilla $=$ Ampelis), Hirundiniformes, de öfriga Turdiformes samt till sist Fringilliformes; - och i det nyaste ornithologiska arbete vi varit i tillfälle att genomögna (Handbok $i$ zoologi; 2 del. Skandinaviens foglar af Aug. Emil Holmgren, Stockholm 1866) uppföras och beskrifvas de till Oscines hörande familjerna, återförda till de af SUnderalL föreslagna grupperna, i följande ordning: först Turdiformes och ibland dessa Scansores, derefter Corviformes, sedan Fringilliformes samt slutligen Hirundiniformes, hvilka sistnämnda i detta arbete likväl föras till en skild underafdelning inom ordningen Passeres och icke sammanställas med de öfriga Oscines.

Denna olikhet i den systematiska ordningsföljden, som man anträffiar vid en anställd jemförelse af skilda arbeten, sträcker sig föröfrigt icke blott till de här framhillna grupperna, utan äfven till de skilda slägterna inom hvarje af desanma. Bland Fringilliformes beskrifier Sunderall 
t. ex. till först slägtet Loxia samt derefter Pyrrhula (inclus. Corythus = Pinicola), Fringilla (inclus. Coccothraustes) och Emberiza. NiLssos uppställer deremot dessa slägten i en alldeles motsatt ordning, nemligen till först slägtet Emberiza samt derefter Fringilla, Pyrrhula, Corythus, Loxia och Coccothraustes.

För att $\mathrm{i}$ allmänhet visa huru långt olikheten $\mathrm{i}$ den systematiska ordningsföljden kan gå, då densamma icke grundas på en förnuftig och derföre allmänt giltig princip, skola vi här endast efter fyra skilda arbeten anföra den ordning, i livilken de i Skandinavien och Finland förekommande hackspettarne uppräknas eller beskrifvas. I Conspectus generum avium af Bonaparte anföras dessa arter $\mathrm{i}$ följande ordning: Gecinus viridis L., Gecinus canus Gmel., Dryocopus martius L., Picus major I., Picus medius L., Picus minor L., Picus leuconotus Bechst. och Apternus tridactylus L. - I Nomenclator avium musei zoologici Berolinensis (Berlin 1854) uppräknas dessa arter deremot sålunda: Dryocopus martius, Apternus tridactylus, Picus leuconotus, P. major, P. medius, P. minor, Gecinus viridis och G. canus. - I Skandinavisk fauna af Nilsson, der alla ifrågavarande arter uppföras under den gemensamma generiska benämningen Picus, beskrifvas desamma i följande ordning: Picus martius, viridis, canus, leuconotus, major, medius, minor och tridactylus, - och i den nyaste bearbetningen af skandinaviens foglar af Holmgren, der alla dessa arter äfvenledes upptagas under det gemensamma slägtnamnet Picus, anföras Picus major, medius, leuconotus, minor och tridactylus förut och Picus martius, viridis och canus deremot till sist.

Dylika exempel kunna framvisas inom alla ordningar utan undantag. Si t. ex. ställer Sundevall (i Lärobok $i$ zoologien) uggleslägtet främst bland roffoglarna, derefter hökslägtet (Falco) samt till sist gamslägtet; Bonaparte uppräknar deremot $\mathrm{i}$ ofvan citerade arbete gamarna till först, derefter hökarna samt ugglorna till sist, o. s. v. Vill man 
jemföra ett större antal författare med hvarandra, kunna nära nog alla möjliga omställningar af den systematiska ordningsföljden uppvisas, och det både emellan genera inom de skilda hufvudgrupperna och mellan arterna inom hvarje särskildt slägte.

Det störande inflytande ett sådant godtyckligt omflyttande af slägten och hela grupper i skilda ornithologiska arbeten måste utöfva på den systematiska uppställningen isynnerhet af sådana samlingar, hvilka innefatta former från alla jordens delar och således icke kunna omställas efter hvarje nytt faunistiskt arbete, bör inses af hvar och en; för vår del känna vi det af egen erfarenhet. Det härvarande universitetets allmänna fogelsamling var nemligen ursprungligen åtminstone approximativt uppställd efter det Cuvier'ska systemet, men under en lång följd af år hade emellertid den temmeligen betydliga mängd arter, hvarmed samlingen småningom riktades, blifvit inställd i densamma af skilda personer och åtminstone till en väsendtlig del efter olika handböcker, i hvilka ordningsföljden af slägten och arter inom de skilda hufvudgrupperna, såsom vi sett, är mycket olika. Hela samlingen råkade härigenom slutligen i en oordning, som knappast kan beskrifvas: flera exemplar af samma art voro oftast uppställda långt från hvarandra i skilda skåp, dels under samma, dels under skilda både generiska - och artnamn, då några sådana öfverhufvud voro utsatta. Under de läseterminer vården af museum jemte den zoologiska professionen varit mig anförtrodd, har jag derföre ansett det nödvändigt att bland annat äfven småningom bringa de ornithologiska samlingarna i systematisk ordning och har vid utförandet häraf sett mig t. o. m. nödsakad att preliminärt uppställa betydliga delar af samlingen på golfvet, för att sålunda kunna sammanställa de kringspridda exemplaren och arterna. Det är äfven under detta arbete jagr mer och mer insett nödvändigheten deraf, att icke blott klasser och ordningar uppställas i systemet efter graden af organernas utveckling 
hos deras representanter, utan att denna princip, för att förekomma allt godtycke i den zoologiska vetenskapen, bör utsträckas ännu längre och äfven finna sin tillämpning vid bestämmandet af den relativa platsen för hivarje grupp, familj, slägte och art.

Redan länge har man känt, att de olika slagen af organer hos samma djurart icke uppnå en lika grad af utreckling. Șålunda kan det inträffa, att t. ex. nutritionsorganerna i allmänhet äro mera utbildade inom en djurgrupp, lokomotionsorganerna inom en annan. Då det således är fråga derom, att efter den olika graden af organernas utveckling i systemet ordna, vare sig klasser, ordningar, familjer, slägten eller arter, måste det naturligtvis på förhand afgöras, åt hvilket slag af organer man i ett sådant fall bör tillskrifva en högre betydelse. Det förnuftsenligaste härrid synes vara, att det animala systemets organer, såsom ensamt tillhörande djuren, alltid böra uppskattas högre, än det regetativa systemets, hvilka åtminstone i förändrad form äro gemensamma med vexterna, och att bland de förra sensationsorganerna äga ett afgjordt företräde framför lokomotionsorganerna. Detta torde omedelbart inses af hvar och en och således här icke behöfva närmare ådagaläggas.

Äfven inom foglarnas klass bör i öfverensstämmelse härmed sensationsorganernas utbildning $i$ främsta rummet bestämma åtminstone de större afdelningarnas eller ordningarnas relativa plats i systemet; likväl saknas ännu noggrannare och isynnerhet komparativa undersökningar om hjernans och hela det öfriga nervsystemets högre eller lägre grad af utveckling inom skilda grupper, och tager man i betraktande den tid, som erfordras för dylika undersökningars anställande, kan man icke ens hoppas att inom den närmaste framtiden få emotse någonting fullständigare i den vägen. I afsigt att vinna någon kännedom om hjernans olika bildning inom skilda grupper af foglarnas klass, har jag visserligen redan för ett par år sedan med biträde 
af några yngre vänner börjat att ihopsamla härtill nödigt material, men antalet af de former inom skilda grupper, som jag hittills lyckats ihopbringa, är ännu alltför obetydligt. Att sluta efter den likhet i bildning foglarnas hjernor i allmänhet visa, är det emellertid föga troligt, att någon säker ledning för mera affina gruppers ordnande i systemet härigenom kan erhållas, åtminstone under närvarande tidpunkt, dả man ännu föga känner funktionerna af hjernans skilda delar och bedömmandet af den lägre eller högre utvecklingsgraden således åtminstone i de flesta fall vore temmeligen osäkert. Deremot kan man ungefärligen, och måhända tillräckligt nog för att sålunda afgöra de skilda ordningarnas inbördes företräde, uppskatta foglarnas intelligens, om vi så få kalla den synbara klokhet och beräkning de ådagalägga i sitt lefnadssätt och i sitt förhållande till den omgifvande döda och lefvande naturen, samt isynnerhet bedömma den mer eller mindre utbildade instinkt eller konstdrift, som de ådagalägga vid byggandet af sina bon. Det är på grund häraf man äfven med allt skäl icke allenast ställer de s. k. sittfoglarna framför springoch simfoglarna, utan äfven, såsom man i sednare tider allmänt gjort, flyttat tättingar och gökartade foglar (skärroch klätterfoglar $=Z$ ygodactyli) framför roffoglarna.

I allmänhet måste det medges att man åtminstone i de flesta nyare ornithologiska arbeten finner de skilda ordningarna temmeligen förnuftsenligt sammanställda och det både med fästadt afseende på utvecklingsgraden af representanternas instinkter äfvensom med hänseende till den affinitet, som förefinnes mellan vissa grupper inom skilda ordningar, - och derföre råder äfven i detta afseende en någorlunda tillfredsställande öfverensstämmelse, hvilket, såsom vi ofvanföre visat, ingalunda är fallet med anordningen af underafdelningarna 0 . s. v.

Näst efter sensationsorganerna måste inom hela djurriket, enligt hrad vi i det föregiende anfört, lokomotionsorganerna ovilkorligen tagas $\mathrm{i}$ betraktande vid bestämman- 
det af enskilda familjers, slägtens och arters relativa plats inom hvarje grupp, och äro dessa organer i ifrågavarande afseende inom foglarnas klass af så mycket större betydelse, då flygförmågan och en härmed öfverensstämmande organisation måste anses som en bland de räsendtligaste och mest framsti̊nde egenheter, bvilken med ytterst få undantag utmärker representanterna af densamma. Den relativa flygförmågan hos skilda fogelarter måste dessutom äfven vid vetenskapens nuvarande ståndpunkt åtminstone approximativt kunna uppskattas, visserligen sällan genom en direkt jemförelse af deras flyghastighet, men väl genom bestämmandet af de organers proportionella utbildning, af hvilka en mer eller mindre skarp eller lätt flygt är beroende. Vingarna äro, såsom hvar och en känner, det egentliga redskapet vid flygandet, och dessa $\mathrm{i}$ sin helhet äfvensom de enskilda pennornas relativa längd kunna, såvidt det är nödvändigt för ifrågavarande behof, temmeligen väl undersökas och uppmätas på skeletter och uppstoppade exemplar. Vingarnas rörelser utföras visserligen med muskler, men det är dock naturligt, att i samma mån de till flygapparaten hörande musklerna äro utvecklade, måste äfven de ben vara utbildade, som tjena dessa muskler till fästen. Användandet af foglarnas flygförmåga som en ledtråd vid bestämmandet af de skilda formernas relativa plats både inom högre och lägre underafdelningar torde således redan på grund deraf kunna förordas, att åtminstone det väsendtligaste materialet för hithörande beräkningar kan utletas ur vanliga zoologiska och osteologiska samlingar.

Vid särskilda tillfällen har jag uttalat mitt ogillande af den Darwin'ska transformationsläran hufvudsakligen p̊̊ grnnd deraf, att de nu lefvande djurarternas geografiska utbredning kring jordens yta omöjligen låter förena sig med de slutsatser, som skulle följa af antagandet, att alla utgångna äfvensom de ännu existerande formerna uppkommit endast från några få ytterst enkelt organiserade väsenden genom en under millioner generationer småningom 
fortgången formförändring. På det man likväl ej må kunna beskylla mig att vid behandilingen af en så vigtig fråga, som den närvarande, der det gäller att bestämma principerna för ordnandet af familjer, slägten och arter inom de skilda grupperna, hafva med förbiseende af det Darwin'ska åskådningssättet endast följt min enskilda uppfattning, vill jag här ảtminstone med några ord försöka ådagalägga, att äfven enligt sagde lära den af mig här föreslagna principen för bestämmandet af fogelarternas relativa plats inom hvarje större eller mindre afdelning är den enda användbara. Förutsätter man nemligen att alla djurarter, så högre som lägre, uppkommit från några fả enkla väsenden genom en under otaliga generationer fortgången och ännu fortgående successiv utveckling i skilda riktningar, borde djurrikets systematiska indelning lämpligast uppställas i form af några stamträd, såsom det äfven blifvit föreslaget; men detta är i sjelfva verket fullkomligen ogörligt, emedan af de föregående generationerna endast ytterst få spår finnas qvar, nemligen i form af petrifikater. Vill man derföre öfverhufvudtaget i öfverensstämmelse med DARwINs åsigt ordna djurriket $\mathrm{i}$ ett vetenskapligt system, kunna de skilda formerna inom hvarje grupp förnuftigtvis uppställas endast efter graden af organernas utveckling; ty då de i hvarje afseende högst outbildade stamföräldrarna säkerligen icke varit begåfvade t. ex. med någon slags flygförmåga, måste man väl, och det äfren af geologiska skäl, anse, att densamma uppkommit först $\mathrm{i}$ en jemförelsevis sednare tid genom organernas utbildning i en derför gynsam riktning, och således böra de former inom hvarje slägte, familj o. s. v. anses sti̊ högst, hos hvilka organerna i denna riktning hunnit till den högsta grad af fullkomlighet.

På grund af alla i det föregående anförda skäl, hvilka öfverhufvudtaget icke torde kunna jäfvas, äro vi fullkomligen öfvertygade om nölvändigheten, att i foglarnas klass alla arter och efter dem naturligtvis äfven genera 
o. s. v. inom hvarje grupp ordnas efter den relativa flygförmågan, utom i sådana fall, der man faktisk känner, att t. ex. representanterna af nigot slägte ntmärka sig grenom en mera utbildad instinkt, eller då man framdeles på grund af anatomiska undersökningar öfver hjernans och det öfriga nervsystemets utveckling kan bevisa, att några art- och generiska former stå högre, än andra inom samma afdelning, som utmärka sig genom en mera utbildad flygförmåga. Att man derjemte alltid, så vidt det är möjligt, bör fästa tillbörligt afseende vid den affinitet, som förefinnes emellan enskilda generiska eller artformer och vid den systematiska uppställningen för den mer eller mindre utbildade flygförmågan icke förbiser denna affinitet, är väl naturligt och behöfver derföre här icke närmare antydas. Genom införande af denna, såsom oss synes, fullkomligen förnuftsenliga princip böra alla godtyckliga bestämningar beträffande den systematiska ordningsföljden af sig sjelf förfalla.

Sedan vi nu i korthet gifvit skäl för den princip vi föreslagit för bestämmandet af fogelarternas relativa plats inom slägten och grupper, skola vi här äfven meddela resultaterna af några beräkningar, som vi anställt öfver enskilda arters flygförmåga. $\mathrm{Vi}$ inse visserligen ganska väl, att dessa beräkningar i många afseenden ännu äro och måste vara bristfälliga; men jemför man de relativa värden, som vi erhållit genom uppmätande af flygorganernas dimensioner hos skilda species och hvilka äro fullkomligen oberoende af arternas storlek, måste det dock medges, att, med några mer eller mindre betydande undantag, som isynnerhet framträda vid en anställd jemförelse emellan arter tillhörande mycket olika grupper och hvilka således till hela sin organiska byggnad ansenligt afvika från hvarandra, dessa siffertal öfverhufvudtaget äro proportionella med den kända olika flyğförmågan hos flere allmänt bekanta fogelarter. Man torde således redan häraf kunna anses berättigad till den slutsats att det ligger inom möjlighetens 
omrảde att med en viss grad af säkerhet beräkna den relativa flygförmågan isynnerhet hos mera affina foglar samt att $\mathrm{i}$ bestämda siffertal uttrycka densamma. Inseende den vigt och betydelse sådana bestämda siffertal i allmänhet måste äga, då fråga är att efter organernss olika utvecklingsyrad inom slägten, familjer o. s. v. ordna skilda djurformer, emedan endast med ledning af desamma hvarje godtyckligt uppskattande fullkomligen kan undvikas, hafiva vi ej tvekat att nu redan publicera våra hittills gjorda beräkningar i förberörda afseende så ofullständiga de än äro, i förhoppning att derigenom möjligen framkalla andra naturforskares samverkan till lösande af denna frảga och till afhjelpande af de bristfälligheter, som tilläfventyrs vidlåda våra beräkningar.

Onekligen kunna skeletter lättast och med den största möjliga noggrannhet uppmätas och då foglarnas organisation, åtminstone sả vidt det beträffar deras flygförmåga, måste stả i den närmaste öfverensstämmelse med benens byggnad och relativa dimensioner, hafva vi äfven ansett det nödvändigt att nästan uteslutande stöda alla beräkningar på skelettets form. I många fall vore det risserligen önskvärdt om man tillika kunde uppmäta t. ex. handpennornas längd, men det borde då ske på samma exemplar och dertill har man jemförelsevis mindre ofta tillfälle - och så vidt det beträffar exotiska former högst sällan. Alla uppmätningar t. ex. öfver öfverarmens längd i förhållande till den öfriga vingens äro på exemplar, der vingbenen icke blifvit rengjorda från alla muskler, högst osäkra och kunna omöjligen begagnas för några hithörande beräkningar, då några millimeter mer eller mindre i de nppmätta dimensionerna framkalla ganska betydliga afvikelser $\mathrm{i}$ de för hvarje art beräknade proportionerna. P̊̊ uppstoppade exemplar, der öfverarmbenen vanligen äro afbrutna, kunna dylika uppmätningar ännu mindre företagas, men på dessa kar man likväl ganska noga bestämma handpennornas inbördes längdförhållanden o. s. v., hvilket åt- 
minstone inom några isynnerhet mindre talrikt representerade slägten kan lemna en temmeligen säker grund för bedömmandet af de dit hörande arternas relativa flygförmåga. Härom likväl utförligare längre fram.

Då ingen af hittills lemnade beskrifningar öfver foglarnas benbyggnad är affattad i en sådan form att den kunde begagnas för ifrågavarande ändamål, har jag varit nödsakad att genom direkta mätningar söka bestämma den relativa utvecklingen af de ben hos skilda fogelarter, af hvilka en mer eller mindre utbildad flygförmåga $i$ väsendtligare afseende är beroende. Sedan några år har jag visserligen redan uppmätt de skilda vingbenen af särskilda fogelarter, som jag händelsevis öfverkommit, och dervid äfven fästat mig vid den $\mathrm{i}$ ögonen fallande olikbeten af deras relativa dimensioner, men med ytterst få undantag, hvilka särskildt angifvas, äro alla här uppgifna måttsbestämningar grundade på nya uppmätningar af exemplar, som förvaras i universitetets anatomiska museum, hvarigenom möjliga misstag när som helst kunna kontrolleras och rättas. Detta museum innehåller nemligen en ganska rik osteologisk samling, hvilken genom sin omsorgsfulla uppställning och sitt vårdade skick utmärker sig framför alla dem jag varit i tillfälle att se. Genom ett sällsynt förtroende af dess grundläggare Herr Professorn och Arkiatern E. J. BonsdorfF har det förunnats mig att under sistförflutna julferier, på en tid då han sjelf var frånvarande, begagna ifrågavarande samling, på livilken sả mycken tid och möda blifvit nedlagd. Jag begagnar detta tillfälle att offentligen betyga Herr Arkiatern min uppriktiga tacksamhet såväl för detta förtroende, som för hans beredvillighet, att ur sitt rika anatomiska och fysiologiska bibliothek låna mig några specialarbeten, hvilka jag fåfängt eftersökt i universitetsbibliotheket.

Innan jag likväl närmare redogör för de ben, hvilka jag af en eller annan anledning ansett nödvändigt att upp- 
mäta, måste jag till undvikande af alla misstag beträffande de här använda benämningarna på förhand upplysa derom, att med nammet nyckelben (clavicula) i denna afhandling alltid betecknas de ben, som vanligen äro kända under benämningen af korpben eller ossa coracoidea, emedan dessa ben både till läge och funktion - och ingalunda det s. k. gaffelbenet (furcula), såsom man i sednare tider allmänt antagit - motsvara nyckelbenen hos menniskan. Beträffande dessa ben yttrade sig den berömde anatomen RETzIUS i ett föredrag, som under titel af Närmare bestämmandet af några muskler för främre extremiteterna hos Fåglarne finnes infördt i Förhandlingar vid de skandinaviske naturforskarnes tredje möte $i$ Stockholm d. 13-19 Juli 1842, p. 659, sålunda: "Då Cuvier, genom utgifvandet af sina föreläsningar i comparativa Anatomien, grundlade ett nytt tidehvarf för denna vetenskap, lade läran om enheten i bildningsplanen endast föga framskridit. Hos fảglarne ansågs furcula ännu såsom ett eget ben, utan motsvarighet hos menniskan. Vida senare fann man, att detta ben icke var annat än de hopsmälta nyckelbenen, och att hvad man förut antagit vara nyckelben, endast var de till en viss sjelfständighet bildade coracoidal-styckena af skuldran. Meckel, som i grunden hyllade denna åsigt, antog tvenne par nyckelben, ett för Acromion och ett för processus Coracoideus, emellertid har den enklare åsigten, såsom den mest naturliga gjort sig temmeligen allmänt gällande, så att enheten $\mathrm{i}$ skuldrans bildning, från menniskan, genom däggdjuren och fäglarne, till oeh med Amphibierne väl kan anses fullkomligen idagalagd." - D̊̊ jag likväl här i fullkomlig strid emot ofvan anförda bestämda påståenden förklarat de s. k. korpbenen motsvara nyckelbenen hos menniskan, anser jag mig böra närmare framställa grunderna härföre och tilltror mig t. o. m. att kunna lemna det fullständigaste bevis för riktigheten af min åsigt.

Hvad först och främst den åt nyckelbenen hos foglarne gifna benämningen af ossa coracoidea beträffar, så 
härleder sig densamma från den äfven af RETzIUs antyda ¿sigten, att dessa ben skulle vara "de till en viss sjelfständighet bildade coracoidal-styckena af skuldran." Egendomligt nog tyckes man ej hafva fästat tillbörlig uppmärksamhet dervid, att processus coracoideus scapulae hos foglarna $\mathrm{i}$ allmänhet, och det endast med ytterst fä undantag t. ex. af de strutsartade foglarna, är så fullkomligen utbildad som man möjligen kan tänka sig det på ett till den grad smalt och outveckladt skulderblad. Föröfrigt äro de af oss som nyckelben ansedda ossa coracoidea hos ingen enda fogelart fästade rid processus coracoideus scapulae (vanligen kallad processus furcularis), utan, såsom förbållandet äfven är med nyckelbenen hos menniskan, vid processus acromialis, d. v. s. den hos foglarne s. k. processus humeralis scapulae. - Processus coracoideus utskjuter nemligen hos menniskan såsom bekant ifrån den inre emot ryggraden vända sidan af skulderbladet, acromion deremot från den $y$ ttre, och vid basen af detta sednare utskott är cavitas glenoidalis belägen, emot hvilken caput humeri artikulerar. Att tyda ofvannämnda utskott på skulderbladet annorlunda än vi hafva gjort det, är att helt och hållet omkasta deras läge. Äfven hos den vanliga strutsen, der de s. k. ossa coracoidea ligga nästan i samma plan med de nedtill från hvarandra alldeles åtskilda gaffelbenen, är det naturligtvis acromion af sknlderbladet, som ligger närmast till cavitas glenoidalis, och härifrån utgår os coracoideum eller det egentliga nyckelbenet; gaffelbenet är deremot till en väsendtlig del sammanvuxet med den motsatta sidan af skulderbladet och utgår således äfven här såsom enligt regel hos andra fogelarter ifrån processus coracoideus scapulae. Redan på denna grund kan således gaffelbenet omöjligen anses motsvara nyckelbenen hos menniskan, och dessutom äro ossa coracoidea liksom nyckelbenen hos menniskan fästade på hvardera sidan vid främre kanten af sternum (manubrium) i en incisura eller cavitas clavicularis, hvilket icke är fallet med gaffelbenet hos en enda fogelart. 
Då det således, enligt hvad vi ofvanföre antydt, i sjelfva verket är gaffelbenet, som utgår från processus coracoideus och ingalunda de egentliga nyckelbenen (vanligen s. k. korpbenen), hade det varit mycket lämpligare att tilldela benämningen af ossa coracoidea åt de begge grenarna af det förstnämnda benet, än att härmed beteckna foglarnas verkliga nyckelben.

Man har utan tvifvel misstydt de egentliga nyckelbenen af flere skilda skäl. Nyckelbenen hafva nemligen hos foglarna bland annat ett något förändradt läge derigenom att de äro riktade betydligt mera bakåt än fallet är hos menniskan. Denna riktning af nyckelbenen står emellertid $\mathrm{i}$ en fullkomlig öfverensstämmelse med foglarnas hela organiska byggnad, hvilken hos de flesta arter af denna djurklass är beräknad för ett dubbelt rörelsesätt, nemligen för flygt samt gång eller språng. Då under hvardera af dessa rörelsesätt hela kroppen naturligtvis måste hållas i jemnvigt, äro för möjligheten häraf de främre (vingarna) och de bakre extremiteterna särdeles närnade till hvarandra och de tyngsta delarna af kroppen mera concentrerade i mellersta delen af undre sidan. Hela den nedre delen af bröstkorgen och isynnerhet bröstbenet, som här till en väsendtlig del tjenar som underlag för kroppens tyngsta delar, är derföre hos foglarna i öfverensstämmelse härmed betydligt dragen bakåt, och då nyckelbenen äro fästade vid och stöda sigg emot främre kanten af bröstbenet, måste deras riktning nödvändigtvis rätta sig efter bröstbenets läge. Dia gaffelbenet $\mathrm{i}$ sjelfva verket till sin riktning, ehuru ingalunda till uppkomst, vidfästning och funktion, skenbart mycket mera öfverensstämmer med nyckelbenens läge hos menniskan, föll man lätt på den tanken att anse detsamma såsom de nedtill med hvarandra sammanvuxna nyckelbenen hos foglarna. Hos strutsen deremot, som helt och hållet saknar förmågan att flyga, ligga nyckelbenen, såsom vi ofvanföre nämnde, nästan $\mathrm{i}$ samma plan med de från hvarandra skilda gaffelbenen, emedan bröstbenet här 
icke är draget emot den bakre delen af kroppen, såsom fallet är hos andra med flygförmåga begåfvade arter.

Äfven till funktion motsvara de s. k. ossa coracoidea nyckelbenen helt och hållet, emedan desamma fixera det ställe, der öfverarmen artikulerar. Undersöker man nemligen närmare den riktning, i hvilken musculus pectoralis major verkar på öfverarmbenet, är det lätt att inse, att hela skulderpartiet vid en kontraktion af denna hos foglarna alldeles ovanligt utbildade muskel och hvarigenom hela vingens slag emot luften framkallas, skulle dragas emot bröstbenet och isynnerhet emot bröstbenskammen, ihändelse ej förenämnda ben, hvilka hos foglarna derföre äfven äro särdeles starkt byggda, skulle motverka detsamma. Det kan visserligen ej förnekas, att skulderpartiet äfven till någon ringare del stödes $\mathrm{i}$ sitt läge af gaffelbenet, isynnerhet genom dess vidfästning vid främre ändan eller spetsen af crista sterni, dermed det stundom t. o. m. är omedelbarligen fastvuxet, men att detta stöd är mycket svagare, kan man bland annat redan sluta af gaffelbenets mycket klenare och svagare byggnad.

Det säkraste beviset emot den åsigten, att gaffelbenet vore de sammanvuxna nyckelbenen hos foglarna, kan man onekligen framställa genom en undersökning om uppkomsten och den rätta betydelsen af detta ben. Vi hafva för detta ändamål undersökt en stor mängd fogelarter och jemfört gaffelbenets form och läge nästan på alla fogelskeletter, som finnas tillgängliga på universitetets anatomiska museum, och skola här i korthet meddela resultaterna deraf.

Såsom man känner uppnår musculus pectoralis major, den väsendtligaste flygmuskeln, en ovanlig grad af utveckling hos foglarna. Till förökande af vidfästningsytan för densamma har icke allenast bröstbenet inom denna djurklass en betydligt större utsträckning i längd och isynnerhet $\mathrm{i}$ bredd, utan detta ben är äfven försedt med en hög uppstående kam. Men det är icke nog härmed, ty ur- 
sprunget af förenämnde muskel *) sträcker sig hos största antalet foglar ännu t. o. m. ett betydligt stycke framom sjelfva bröstbenet. Vore den organiska byggnaden hos foglarna vid främre delen af bröstkorgen alldeles lika med den hos menniskan, skulle m. pectoralis major här helt och hållet sakna en vidfästningsyta, men hos representanterna af denna djurklass finnes framom bröstbenet och emellan de egentliga nyckelbenen en senig membram af betydlig utsträckning, som här tjenar ifrågavarande muskel till vidfästningyta. Genom Herr Anatomie Prosektorn D:r G. R. BJörkstens förekommande välvilja har jag varit i tillfälle at på tvenne skilda menniskolik jemföra alla de ligamenter, som stå $\mathrm{i}$ något sammanhang med hithörande delar, och har dervid kommit till fullkomlig öfvertygelse derom, att förenämnda membran omöjligen kan anses motsvara någonting annat än det för ofvanuppgifna ändamål hos foglarna till en särdeles utvecklingsgrad komna ligamentum interclaviculare eller semilunare, såsom det äfven kallas. Formen af detta ligament rättar sig hos skilda fogelarter i allmänhet efter skapnaden af bröstbenets framsida och består oftast icke blott af en mera horizontal del framför främre kanten af sternum och emellan de nedre, d. v. s. bakre, emot bröstbenet vända och mera utplattade delarna af de egentliga nyckelbenen, utan från detsamma utgår på hvardera sidan en del i mera vertikal riktning och öfre kanten af dessa mera vertikalt ställda delar af membranen närma sig mer eller mindre bågformigt hvarandra samt förena sig vanligen till en enda senig hinna, som ligger i samma plan med crista sterni och är fästad vid hela dess främre kant ända till spetsen. Framåt sträcker sig ligamentum interclaviculare hos foglarna icke blott längs hela inre sidan af hvardera nyckelbenet, ehuru det småningom

*) Se härom C. G. Scroepss' utmärkta afhandling Beschreibung der Flügelmuskeln der Vögel i Meckel's Arcliv für Anatomie and Physiologie. Jahrg. 1829, p. 108-112. 
afsmalnar och lemnar i midten emellan hvardera sidan en framtill mycket bredare öppning, utan går t. o. m. förbi och fäster sig vid den inre kanten af den s. k. tuberositas furcularis eller yttersta krokiga framändan af de egentliga nyckelbenen samt går härifrån till processus coracoideus scapulae. I likhet med den böjelse likartade delar hos foglarna i allmänhet visa att ossifieras, uppstår inom främre kanten af detta ligament hos de flesta arter en ossifikation och denna benbildning antar derföre äfven så långt den sträcker sig formen af ligamentets in-och framsida. Detta är gaffelbenets verkliga uppkomst och derföre har detsamma såsom ben, i fullkomlig öfverensstämmelse med den gamla åsigten, icke någon motsvarighet hos menniskan. Ossifikationen inom främte kanten af förenämnda ligament sträcker sig föröfrigt icke lika långt hos alla arter. Stundom förbenas t. o. m. hela trämre kanten af den vertikala delen framför bröstbenskammen (det s. k. ligamentum sterno-furculare) och i denna händelse sammanvexer vanligen spetsen af gaffelbenet helt och hållet med spetsen af bröstbenskammen, såsom fallet t. ex. är hos tranan och pelikauen (åtminstone hos Pelecanus crispus Bruch.), men vanligen sträcker sig denna ossifikation icke så långt, utan intager endast en del af det vertikala partiet, så att den aterstående delen af ligamentets framkant qvarstannar i sin ursprungliga membranartade form emellan den s. k. apex furculae och spetsen af bröstbenskammen. Denna förbening synes föröfrigt icke uppstå samtidigt långsmed hela kanten, utan fortgå successivt. Bernstern yttrar härom i sitt arbete De anatomia corvorum (Vratislaviae 1853), p. 43: "In eo osse (furcula!), quod nomen e forma cepit, ramos duos dignoscimus, qui in apicem s. symphysin conveniunt, supra auten per extremitates humerales cum ossibus coracoideis et scapulis cohaerent. Meursinge affirmat (Verhandeling p. 109), ramos illos duos in corvis pullis separatos sero inter se coalescere; quod dictum equidem probare nequeo, quippe qui hoc os in recens natis semper simplex 
nec unquam vestigia fissurae pristinae invenerim. Sed laminam osseam, quae perpendiculi ratione symphysi insidet et apex furculae vocatur, in neonatis corvis cartilagineam inveni." - Stundom åtminstone inträfrar hela denna förbeningsprocess ännu mycket selnare. P̊ universitetets anatomiska museum förvaras ett ungt, likväl mer än halfvuxet exemplar af den afrikanska strutsen, der de emot gaffelbenets bågar svarande delarna endast utgöras af broskartade ligamenter, *) och äfven på detta exemplar ser man ganska tydligt, att desamma utgå från ligamentum interclaviculare. Inom flere grupper, t. ex. hos roffoglarna, förbenas endast yttre kanten af de mer eller mindre bågformiga sidodelarna, som hufvudsakligast utg̊a från inre sidan af nyckelbenen (d. v. s. det s. k. ligamentum sterno-furculare coracoideum), utan att någon apex furculae uppstår, och i denna händelse bildar hela gaffelbenet endast en nedåt böjd båge, som på hvardera sidan utgår från processus coracoideus scapulae tätt förbi tuberositas furcularis på nyckelbenen. Stundom sträcker sig ossifikationen icke ens så långt emot bröstbenets kam, utan begge bågarna förblifva nedtill skilda

*) Staxsius anfür i Lehrluch der Vergleichenden Anatomie der Wirbelthiere, Berlin 1846 , p. $25 \%$, följande beträffande dessa ben hos de strutsartade foglarna: "Die Schulter der Struthionen zeigt sich dadurch eigenthümliclı, dass die drei Elemente des Schultergerüstes jeder Seite mit einander zu einem einzigen Knochen versclimelzen und dass die Claviculae bei Apteryx, beim indischen Casuar und bei Phea americana kaum, bei Struthio camelus und beim neuholländischen Casuar dagegen sehr bestimmt als starke, vorzüglich bei letzterem convergirende - wenn auch unvereinigt bleibende - Fortsät\%e angedeutet sind.' Beim nenholländischen Casuar bleiben die das Brustbein nicht erreichenden Claciculae während der grössten Zeit des Lebens eigene Knochen, während das Os coracoideum frühzeitig mit d॰r Scapula verwächst. Beim jungen afrikanischen Strauss finde ich Scapula und Os coracoideum als getrennte Knochenstücke; die nach innen vor dem Os coracoideum gelegene Clavieula, welche ron jenem später nur durch eine Oeffnung theilweise getrennt bleilt (s. d'Alton Tab. VII, fig. g), ist noch ganz ligamentüs, ohue Spur ron Verknöcherung und erstreckt sich zum Brustbeine." 
från hvarandra, såsoin fallet är med gaftelbenet hos Athene (Strix) passerina L. (enligt exemplar på universitetets anatomiska museum); hos åtskilliga papegojor inträffar, såsom man känner, aldrig någon förbening i detta liganent, tillfölje hvaraf dessa arter helt och hållet sakna ett gaffelben. *)

Såsom ofvanföre uppgafs, sträcker sig ursprunget af musculus pectoralis major genom sin betydliga utreckling hos de flesta foglar framom sjelfva sternum öfver ligamentum inter claviculare, och då framsidan af detta ligament förbenas, vinner förenämnda muskel ett så mycket stadigare fäste. - Då fästet af denna muskel på bröstbenet hos foglarna mera höjes emot bröstbenets kam, för att med desto större kraft direkte kunna verka på öfverarmbenet, och hela muskeln derföre kommer att ligga öfver och ingen del af densamma utgår ifrån nyckelbenen såsom hos menniskan, trodde man sig naturligtvis i denna muskels delvisa uppkomst från gaffelbenet finna ett ytterligare stöd för den åsigten, att gaffelbenet $i$ sjelfva verket vore de nedtill sammanvuxna nyckelbenen hos representanterna of denna djurklass. Den omständigheten, att ingen del af musculus pectoralis major hos foglarna utgår från nyckelbenen, betyder likväl såsom här beroende af bröstkorgens byggnad i sjelfva verket ingenting, ty härom gäller hvad

") Staxicis yttrar härom i Lehrbuch der vergleichenden Anatomie der Wirbelthiere, p. 256 \& 257: "Selten sind die beiden Claviculae unten nur knorpelig oder bleiben unvereinigt, oder fehlen ganz. Sie bleiben unten knorpelig bei Strix ulula nach Meckel; bei Strix flammea sah sie Nitzsch constant in ein seitliches Knochenpaar zerfallen; ebenso Meckel bei Buceros nasutus (während Owen bei $B$. cavatus sie rerbunden fand); ich bei mehreren Rhamphastos spec. dub.; vielen Papageien fehlt die Furcula gänzlich; so, nach Figors in Taylor' sPhilos. Magaz. 1831, N:o 51, p. 232, bei Ps. mitratus, eximius und galgulus; nach Nitzsch (System der Pterylographie S. 145) bei allen Platycerci und bei Ps. pullarius; ich vermisste sie ausserdem auch bei Psittacula passerina. S. auch Kuhlmann, De absentia furculae in Psittac. pullario, Kil. 1841, 8." - Äfven pá unirersitetets anatomiska museum finnas âtskilliga papegojor, som helt och hallet sakna gaffelbenet. 
Retzius yttrar ( $\mathrm{på} \mathrm{ofvan} \mathrm{anfördt} \mathrm{ställe} \mathrm{p.} \mathrm{661)} \mathrm{beträffande}$ en annan muskel: "Det synes häraf att denna, så väl som flere andra muskler, kan förändra form och fästen efter mekanismen af de närmaste benen och ledgångarne."

Öfvervägas alla här anförda fakta, som tala för den åsigten, att de s. k. ossa coracoidea motsvara nyckelbenen hos menniskan, torde man finna, att en annan tydning af desamma knappast är möjlig. Vi hafva derföre äfven ansett det tillbörligt att beteckna dem med dessa deras rätta namn.

Såsom bekant skilja sig foglarnas ben från de öfriga ryggraddjurens genom sin egenskap att sakna märg och vara ihåliga, men deremot fyllda med luft, som intränger från lungorna genom stora, inuti kroppen belägna luftsäckar. Genom denna egenhet i benbyggnaden blir foglarnas kropp specifikt mycket lättare, och graden af benens såkallade pneumacitet står hos skilda arter, såsom man har all anledning att förmoda, $i$ ett temmeligen direkt förhållande till deras flygförmåga. Hos fogelarter, som helt och hållet sakna denna förmåga, äro nemligen endast några af hufvudskålens ben luftfyllda, då deremot de flesta ben äro pneumatiska hos dem, som äro utmärkta genom en snabb och uthållande fiygt. Hållas fogelben emot dagsljuset, synas alla de genomskinliga, som äro pneumatiska, och man kunde härigenom åtminstone approximativt bedömma graden af denna egenskap hos benen af skilda arter; men att i bestämda siffertal uttrycka densamma, torde deremot möta nästan oöfverstigliga svårigher. Ehuru foglarnas förmåga att svinga sig upp till en viss höjd i luften $\mathrm{i}$ väsendtlig mån måste vara beroende af benens pneumacitet, synes densamma $\mathrm{i}$ sjelfva verket dock $\mathrm{i}$ en proportionsvis ringare grad kunna bidraga till flyghastigheten, hvilken hufvudsakligen betingas af vingarnas byggnad och muskelstyrkan. Det är dessutom troligt, att benens pneumacitet står i nära samband med deras ändamålsenliga byggnad i öfrigt, och att de resultater man genom närmare undersökningar öfver 
förhållandet hos skilda arter i detta afseende kunde vinna, skulle öfverensstämma med dem, till hvilka man mycket lättare leder sig genom en direkt uppmätning af benens relativa dimensioner, och derföre endast tjena att bestyrka riktigheten af desamma.

Flyghastigheten och den lätthet, hvarmed foglarna kunna fortskaffa sig genom luften, beror utan tvifvel i främsta rummet icke allenast på vingarnas längd i proportion till kroppens, utan äfren på de enskilda vingbenens inbördes längdförhållanden. Foglar, som äro kända för en lätt och sväfvande flygt, hafva nemligen enligt regel mycket långa vingar; de som utmärka sig genom en skarp flygt, hafva deremot öfverarmbenen proportionsvis korta i förhållande till de öfriga vingbenens längd. För att kunna uttrycka dessa förhållanden i bestäıda siffertal, är det således nödvändigt att på skelettet uppmäta icke allenast hela vingens och öfverarmbenens, utan äfven kroppens längd. Dylika proportions-bestämningar, ehuru endast ungefärliga, hafva visserligen redan förut blifvit använda för att $\mathrm{i}$ allmänhet karakterisera hela grupper eller vissa former. Det är i sådant afseende som Sundevall i sitt förtjenstfulla och allmänt kända arbete Om foglarnas vingar *) yttrar sid. 323: "Längden af vingbenen kan endast bestämmas genom jemförelse med truncus, och denna måste beräknas från skullran till stjertens sista verteber (stjertroten eller stjertfästet) hvarpå Rectrices äro fästade. Skullran utmärkes af den mest framstående ändan (eller processen) af os coracoideum, som emottager clavicula (furcula), och som tydligt kännes under huden näst framom humerus. Humeri ledgång ligger straxt bakom denna knöl, vid främre delen af sjelfva truncus. Första bestämningsgrunden blir alltsæ̊ att mäta huru långt det bakre vingvecket (armbågen eller bakre ändan af humerus och cubitus) räcker på truncus då

*) Kongl. Vetenskaps-Akademiens Handlingar för à 1813, Stockholm 1844 . 
vingen är hoplagd. Af alla foglar har Diomedea exulans, som har de flesta armpennor, äfven de längsta vingben. Dessa räcka nemligen betydligt (med 1/13, eller 32 millimeter) utöfver kroppens bakre ända. Kortast äro de hos Trochilus och Cypselus, hos hvilka de ej uppnå fullt $1 / 4$ af truncus ..." o. s. v.

Vill man endast $i$ allmänhet erhi̊lla en ungefärlig föreställning om dessa längdförhållanden, kunna dylika uppmätningar visserligen anses tillfyllestgörande, men för noggrannare beräkningar öfver fogelarternas relativa flygförmåga kunna desamma såsom alltför obestämda icke begagnas. Vi hafva derföre ansett det nödvändigt att så noga som möjligt utröna benens verkliga dimensioner. För sådant ändamål hafva vi sökt att p̊̊ skeletter bestämma längden af truncus efter afståndet från början af den första bröstkotan ända till den sista af stjertens vertebrer (vertebrae coccygeae), hrilken vi här för korthetens skull helt enkelt beteckna med det nog ofta använda namnet os coccygis. Oaktadt all använd omsorg, har en viss osäkerhet vid uppmätningen af detta afstånd stundom icke kunnat undvikas. Hos somliga arter äro nemligen de med korsbenskotarna sammanvuxna bäckenbenen ganska kullriga på öfre sidan, hvarigenom den noggranna uppmätningen af kroppens hela längd betydligen försvårats, och på flere exemplar i universitetets anatomiska museum bilda stjertens vertebrer, genom den ställning de vid preparationen tillfälligtvis eller med afsigt erhållit, en uppåtböjd båge, hvars egentliga längd varit ytterst svår att bestämma. Vi hafva visserligen i mănga fall genom uppmätande af de skilda delarna och genom summering af deras längd sökt att noggrannare bestämma hela längden af truncus, men vi inse ganska väl, att några af dessa uppmütningar det oaktadt icke äro fullt pålitliga.

Till vinnande af större noggrannhet hafva vi särskildt uppmätt alla de ben, livilka tillsammans bestämma hela vingens längd, och har detta varit så mycket mera nöd- 
vändigt, som vingbenen på alla skeletter i härvarande anatomiska museum äro ihoplagda i den naturliga ställning, hvilken de intaga då foglarna icke flyga. Genom denna partiella uppmätning kunna dessutom icke allenast vingbenens inbördes längdförhållanden lättare öfverses, utan äfven möjliga misstag i sjelfva uppmätningen upptäckas. Föröfrigt hafva vi ansett oss böra uppmäta vingbenen på den sida, der en längdbestämning på ett skelett är lättast utförbar. Största längden af öfverarmbenet är derföre uppmätt på öfre sidan; underarmens längd är bestämd efter längden af ulna, emedan detta ben icke allenast är det mest utbildade $\mathrm{i}$ cubitus, utan äfven emedan det är lättast uppmätt på ett uppstäldt skelett. Uppgiften öfver längden af benen $\mathrm{i}$ handlofven (carpus) är öfverhufvudtaget något osäker; det har nemligen varit ytterst svårt att beräkna den tillökning $\mathrm{i}$ hela den utsträckta vingens längd dessa hos skilda foglar till formen något afvikande ben $\mathrm{i}$ sjelfva verket framkalla. - Os metacarpi äfvensom lederna af det s. k. mellanfingret (index) äro alltid uppmätta vid yttre (radial-)kanten. Accessoriska vingben, som förekomma hos några arter och hvilka icke bidraga till vingens längd, äro ej tagna i beräkning.

Särskildt bör anmärkas, att alla här angifna längdmått till en viss ehuru ringa grad äro osäkra tillfölje af den begagnade skalans något olikformiga indelning, som likväl röjer sig endast när det gäller smärre bråkdelar af millimetern.

Då fogelns vinge liksom menniskans arm måste betraktas som en enarmig häfstång, anser väl mången, och det med rätta, att vi för bedömmande af hithörande proportioner på hvarje exemplar bort uppmäta afståndet emellan den yttersta ändan af caput brachii och det ställe på öfverarmbenet, der musculus pectoralis major är fästad, och i sjelfva verket hyste vi i början den förhoppning att genom uppmätning af detta afstånd och genom ett samtidigt uppskattande af den vid flygten använda muskelstyrkan 
lättast kunna beräkna flygförmågan hos skilda arter. Utförandet häraf har likväl strandat emot oöfverstigliga hinder. Ofvannämnda muskel är hos foglarna icke fästad inom ett alldeles inskränkt omräde, utan utbreder sig*) antingen endast öfver den yttre ytan af den öfre spina humeri, eller hos några arter tillika öfver en linie, som utgår från början af den nedre spina humeri snedt uppåt och framåt ända till slutet af den öfre. $D_{a}$ vidfästningsytan derjemte icke har samma bredd på alla ställen, skulle beräkningen af medelafståndet af muskelns vidfästning från caput brachii**) hos skilda species vara åtminstone $\mathrm{yt}$ terst svår.

Vi hafva ofvanföre uppgifvit, att de foglar, som utmärka sig genom en snabb flygt, hafva öfverarmbenen proportionsvis korta i förhållanden till de öfriga vingbenens längd. Detta förhållande beror af fysiska skäl, som vi skola försöka att förklara. Såsom man känner, hafva utmärkta flygare $\mathrm{i}$ allmänhet långa vingar; men med vingarnas tilltagande längd ökas naturligtvis äfven svårigheten att utföra vingslagen, i det härigenom lastens afstånd från den enarmiga häfstångens understödspunkt tilltager. Lasten motsvaras här, såsom hvar och en lätt inser, af luftens motstånd emot. vingarnas undre yta. Alla de delar af vingen, som bidraga att föröka dess längd, utan att i väsendtlig mån föröka den emot luften utbredda ytan, måste derföre framkalla ett för en snabbare flygt ogynsamt förhållande. På öfverarmen sitta inga längre pennor, utom i högst få fall, dì några af de innersta, enligt regel således äfven de kortaste, cubital-pennorna öfverskrida armbågen. Ju kortare öfverarmen är, med desto större kraft kunna

*) Se härom utförligare i Schoepss' ofvan citerade arbete, som finnes intaget i Meckel's Archiv.

**) Vi beteckna, såsom äfven andra gjort, den öfre ändan af öfverarmbenet med samma namn, som den bär pâ menniskans skelett, ehuru det måste medges, att ett caput brachii i egentlig mening icke förekommer hos foglarua. 
derföre vingslagen utföras. Med underarmens och handens längd är förhăllandet deremot helt annorlunda. P P underarmens hela bakre (ulnar-) sida äro cubital-pennorna eller de s. k. remiges secundariae fästade, hvilka i väsendtlig mån bidraga till förökande af vingens utbredda yta, och deras antal tilltager, enligt Sundevall's noggranna undersökningar öfver organisationen af foglarnas vingar, i allmänhet $\mathrm{i}$ förhållande till underarmens längd. $\mathrm{F}_{a}^{\circ}$ handen är antalet af smällpennorna (remiges primores eller primariae) visserligen föga variabelt, då de flesta foglar hafva tio, ett jemförelsevis mindre antal nio och temmeligen få elfva; men tillfölje af dessa pennors vidfästningssätt, bidrager längden af os metacarpi och af mellanfingrets leder på ett väsendtligt sätt att föröka längden af vingarnas utbredda yta. Remiges primariae äro nemligen fästade på handen i en sned riktning, mera långsåt sjelfva benen, och det enligt Sundevall's undersökningar sålunda, att den första, eller den vid yttre kanten, sitter på yttersta (2:dra) fingerleden (nemligen af mellanfingret), den andra, tredje och fjerde på första fingerleden och de sex áterstående på metacarpus. Antalet af smällpennor, som är fästadt på de skilda delarna af handen, tyckes vara lika hos alla arter, som hafva tio remiges primariae, åtminstone har det äfven varit fallet med alla dem, hvilka jag varit $\mathrm{i}$ tillfälle att undersöka. För att i någon mån bidraga till kännedomen om handpennornas vidfästning, vill jag i förbigående omnämna, det jag vid anställd undersökning öfver förhållandet i detta afseende hos Podiceps auritus L., Sundev. (cornutus Lath.), som hör till ett af de fả genera, hvilka hafva elfva handpennor, funnit den första af dessa pennor fästad långsmed mellanfingrets andra led, den 2-4 pa mellanfingrets första led och den 5:te till och med den 11:te på metacarpus. *)

*) Sundevall tillägger i en not (1. s. c.) p. 317: "Hos hafsänderna (A. glacialis \&c.) finnes en ganska liten 3:dje fingerled" (nemligen på mel- 
Då nu, såsom of vanföre blifvit anfördt, den första handpennan är fästad långsmed den andra leden af mellanfingret och den innersta handpennan sitter temmeligen nära basen af os metacarpi, är det naturligt, att de främre remiges primariae framskjutas ungefär i samma förhållande som benen i handen äro förlängda. Detta förhållande torde bäst kunna upplysas genom ett exempel. På ett exemplar af Podiceps auritus har jag uppmätt de skilda handpennorna och voro dessa af följande längder:

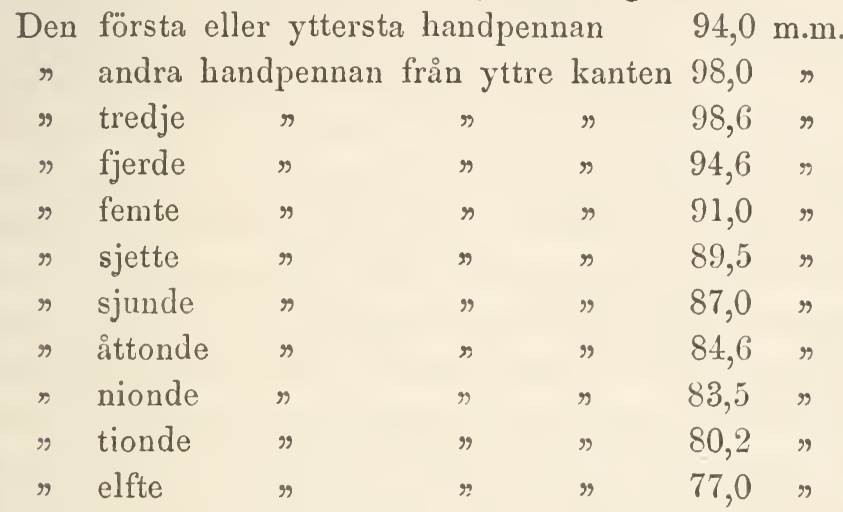

Genom sin sneda vidfästning längs handen skjuter emellertid den första pennan, som är 4 m.m. kortare än den nästföljande och 17 m.m. längre än den elfte, på sjelfva vingen ungefär lika långt fram som den förra och $52 \mathrm{~m} . \mathrm{m}$. framom spetsen af den sednare; den andra pennan, som är 21 m.m. längre än den sista, räcker 52 m.m. framom den-

lanfingret), "som b̈̈r en rudimentär 1:sta penna med sin lilla täckfjäder. Liksâ hos C'ria troile och alle, men ej hos grylle eller Alca torda." - En proportionsvis liten, stundom alldeles rudimentär och ibland med den föregående åtminstone till en del sammanruxen tredje fingerled tyckes fimmas hos ett stort antal simfoglar. Detta är t. ex. fallet hos arterna af slägtet Cygnus (åtminstone hos C. olor och C. musicus), troligen hos alla species af det allmänna genus Anser (åtminstone hos Anser scgetum och Bernicla torquata), hos Anas (Querquedula) crecca o.s. v. - Till och med hos Podiceps auritus L. tyckes förekomma en knappast balf millineter lâng tredje fingerled. 
samma; den tredje, som i sjelfva verket är den längsta och 21,6 m.m. längre än den sista, skjuter endast 49,4 m.m. framom densamma; den fjerde, som är 17,6 m.m. längre än den sista, öfverstiger densamma på vingen med en längd af 41,6 m.m. o. s. v. - Man ser häraf på det tydligaste, att längddimensionerna af benen $i$ handen i ganska väsendtlig grad inverka på längden af den yta, som handpennorna öfvertäcka då vingen utsträckes. I händelse alla remiges primariae äro ungefär af samma längd, hvilket Sundevall anser som det typiska förhållandet hos foglarna, måste vingen genom det beskrifna vidfästningssättet blifva temmeligen regelbundet tillspetsad. Hos ganska många fogelarter, och, såvidt jag kan erinra mig, t. o. m. hos alla dem jag varit i tillfälle att undersöka, är antingen den första eller någon af de första dock märkbart längre än de öfriga, och efter denna hvar och en af de följande emot handlofven $\mathrm{i}$ ordning litet kortare. Denna skilnad emellan de främre och de innersta handpennornas längd är, såsom man känner, på långt när ej lika hos alla arter eller inom alla grupper, men står i ett temmeligen direkt förhållande till benens längd $\mathrm{i}$ metacarpus och $\mathrm{i}$ mellanfingret. Till följe häraf kan man äfven genom uppmätande af vingbenens dimensioner bestämma vingarnas relativa längd hos skilda fogelarter, utan att behöfva fästa särskildt afseende på handpennornas längd.

För att lättare kunna jemföra hela handens längd hos skilda arter med hvarandra, hafva vi ansett det nödigt att för hvarje art angifva den sammanlagda längden af os metacarp $i$ och mellanfingrets leder. Till denna summa hafva vi ej lagt längden af benen i carpus, emedan desamma på uppställda skeletter, åtminstone hos dem med ihoplagda vingben, stanna vid ändan af underarmen, och äfven på en lefvande fogel, såsom belägna i sjelfva vingleden, ej bidraga till handens förlängning, åtminstone då den hålles $\mathrm{i}$ hvilande ställning.

Då nu således, såsom vi ofvanföre visat, en större 
längd af öfverarmbenet framkallar ett för en snabbare flygt ogynsamt, de öfriga vingbenens längd deremot ett gynsamt förhållande, synes det antagligt, att förmågan af en mer eller mindre skarp flygt såvidt den beror af vingbenens proportioner kan uttryckas genom det tal, som man erhåller genom att dividera öfverarmens längd i den öfriga vingens. Genom denna enkla beräkning erhåller man t.ex., ihändelse de af oss uppmätta exemplaren läggas till grund, för den afrikanska strutsen talet 0,79, - för den tama hönan 1,67, - för hjerpen 1,92, - för orren 1,946, - för tjädern 1,968, - för rackelhanen eller bastarden af de båda föregående arterna 1,959, som ligger emellan de för stamformerna beräknade talen, - för skatan 2,31, - för kråkan 2,37, - för korpen 2,49, - för den tama dufvan 2,77, - för hussvalan 3,73, - för ladusvalan 3,88 samt för tornsvalan talet 5,76. Inskränker man beräkningen endast till ofvanuppräknade species, kunde man lätt falla på den tanken, att ifrågavarande proportion är ensam tillräcklig för bestämmandet af fogelarternas relativa flygförmåga, emedan de erhållna talen ungefär synas motsvara den kända flyghastigheten hos dessa allmänt bekanta former; i sjelfva verket synes detta vara fallet, då det endast är fråga derom att inom vissa grupper bland de foglar, som hafva baktån ställd i samma plan med de öfriga, afgöra arternas företräde framför hvarandra inom samma genera, emedan dessa enligt regel till hela sin öfriga organiska byggnad ganska mycket öfverensstämma med hvarandra. Gäller det deremot att åtminstone approximativt jemföra flygförmågan hos former, hvilka tillhöra mindre affina grupper, kan man lätt finna, att denna beräkning icke är tillfyllestgörande. Vi skola anföra ett enda exempel, som är tillräckligt att bevisa det sagda. Dividerar man nemligen öfverarmbenens längd hos Spheniscus demersus L. i de öfriga vingbenens tillsammanstagna, erhåller man talet 1,97. Hos denna fogel, som helt och hållet saknar förmågan att flyga, äro vingbenens relativa dimensioner således mera ändamålsen- 
liga för utförandet af kraftiga vingslag, än fallet t. ex. är hos den tama hönan, lijerpen och orren. Denna omständighet finner likväl sin förklaring deri, att bemälde fogelart åtminstone stundom begagnar sina vingar såsom ett slags lokomotionsorganer vid simmandet och isynnerhet vid dykandet, hvarvid påtagligen ganska starka vingslag erłordras, för att öfvervinna vattnets motstånd. För flygandet erfordras likväl, utom att en fogelart naturligtvis måste hafva utbildade vingpennor, en annan ganska vigtig omständighet, nemligen den, att alla vingbenen tillsammans äga en tillbörlig längd $\mathrm{i}$ förhållande till kroppens dimensioner. Tager man denna faktor med i beräkningen, på sätt längre fram skall visas, erhålles för den tama hönan ett tal, som betydligt öfverstiger det för Spheniscus demersus. Flere fogelarter utmärka sig dessutom genom en slags sväfvande flygt, hvilken i jemförelsevis ringa grad tager kraftiga vingslag i anspråk, och derföre mindre är beroende af öfverarmbenens kortare dimensioner, än af hela vingens längd. Sundevall säger visserligen om denna slags flygt i ofvan citerade arbete, sid. 331: "Det tyckes t. ex. vara tydligt, att de bäst flygande foglarna, som med stilla vingar sväfva, eller liksom segla fram i luften, vanligen i stora kretsar och till en ofantlig höjd, endast äga denna förmåga genom den stora $\mathrm{yta}$ som bildas af långa och talrika armpennor; t. ex. Vultur, Aquila, Milvus, Ciconia, Grus. Denna sortens flygt är den skönaste af alla, och torde böra anses såsom den högst utbildade; ty dels kunna dessa foglar längst fortfara att flyga, dels kunna de alltid, då det behöfves, flyga lika så fort som de bästa öfriga, pilsnabbt kasta sig ned från den ansenligaste höjd o. s. v." - Då likväl hos hönsfoglarna, som äro kända för sin tunga flygt, i allmänhet förekommer ett proportionsvis ganska stort antal armpennor, och tjädern t. ex. har tre stycken remiges secundariae mer än kungsörnen, samt armpennorna hos densamma derjemte äro af en nog ansenlig längd, är det väl snarare troligt, att denna ofvanföre omnämnda lätta 
och sväfvande flygt hos somliga fogelarter i mycket högre grad är beroende af vingarnas totala längd, än af armpennornas antal och dimensioner. Vi skola äfven försöka att med bestämda siffertal ådagalägga riktigheten af vår åsigt. Dividerar man det af oss uppmätta afståndet från den första bröstkotan ända till os coccygis i hela vingens längd hos följande arter, som höra till de af Sundevall särskildt framhållna genera, erhålles för kondoren eller Sarcoramphus gryphus L. äfvensom för Vultur fulvus Gmel. talet 2,92 -, för ett äldre individuum af Aquila chrysaëtus L. (från Helsinge) 2,64 och för ett påtagligen yngre exemplar (från Uskela) 2,88 -, för gladan eller Milvus regalis Briss. (Falco Milvus L.) 2,81 -, för den vanliga hvita storken eller Ciconia alba 2,65 (?) samt för tranan talet 2,28. För tjädern deremot, hvilken, såsom vi of'vanföre omnämnde, har tre armpennor mera än Aquila chrysaëtus, erhåller man genom samma beräkning talet $1,59-$, för hjerpen och den tama hönan endast 1,39. - Sundevall säger dessutom sjelf, att många svagt flygande foglar hafva långa armpennor och således breda vingar (t. ex. arter af genera Parus och Sylvia). Äfven hos de arter, som utmärka sig genom särdeles uthållande flygt, äro vingarna i förhållande till kroppens dimensioner mycket långa. Dividerar man nemligen längden af truncus på det af oss uppmätta exemplaret af albatrossen eller Diomedea exulans L. i hela vingens längd, erhåller man det jemförelsevis ganska höga talet 3,27. Visserligen anträffas hos denna fogelart det största antalet armpennor, nemligen 38 enligt Sundevall (40 enligt Nıtzsch), men vingarnas längd hos albatrossen beror säkerligen ej allenast af underarmens dimensioner, ty på det af oss uppmätta exemplaret af denna art är os humeri af 392 och ulna af 397 millimeters längd, således endast 5 m.m. längre än öfverarmbenet. Af allt detta torde sáledes framgå, att flygten hos en fogel i samma grad blir lättare och mera sväfvande som r?en af hvardera vingen öfvertäckta ytan utsträckes i längd, d. v. s. ifrån kroppen utåt. Här- 
med öfverensstämmer äfven det förhållande, att de fogelarter, som i timtal sväfva öfver vattenytan för att uppsnappa fisk, alltid äro försedda med mycket långa vingar. Då derjemte kraftiga vingslag, såsom vi ofvanföre visat, äro beroende af öfverarmens kortare dimensioner i förhållande till den öfriga vingens längd, måste graden af vingarnas ändamålsenliga byggnad för en utmärkt flygt hos foglarna i öfrerensstämmelse härmed uppskattas i direkt förhållande till hela vingens och $\mathrm{i}$ omvändt förhållande till öfverarmbenens längd.

Den muskelstyrka, hvarmed vingslagen utföras, kan åtminstone i många fall till en viss grad afhjelpa bristen i vingarnas ändamålsenliga byggnad, och densamma måste isynzerhet hos sådana arter, hvilka äro utmärkta genom en uthållande flygt, vara af den högsta betydelse. Ehuru det torde blifva svårt att beräkna, till hvilken grad muskelstyrkan $\mathrm{i}$ allmänhet hos hvarje art bidrager till flyghastigheten, är det likväl en möjlighet att åtminstone approximativt uppskatta den muskelstyrka, hvarmed vingslagen utföras, och äfven detta kan i många fall vara af vigt; ty $\mathrm{i}$ sådana fall t. ex., då tvenne arter hafva en lika ändamålsenlig byggnad af vingarna, måste naturligtvis en mera utbildad muskelstyrka tagas i beräkning, då det är fråga derom att efter lokomotionsorganernas relativa utveckling afgöra deras ordningsföljd i systemet. Det är utom allt tvifvel att flera bland de 48 skilda muskler, hvilka förekomma i foglarnas vingar och omständligt beskrifvas af SCHOEPSS i Meckel's Archiv (årg. 1829), åtminstone till någon del äga sin betydelse vid vingarnas rörelse under flygten; men, såsom vi redan ofvanföre omnämnt, utföras sjelfva vingslagen af musculus pectoralis major, och det är derföre styrkan af denna muskel, som här egentligen bör komma i beräkning. Vi hafva i det föregående beskrifvit, i hrilken riktning denna muskel verkar på öfverarmbenet, samt derjemte framhållit, att det är nyckelbenen hos foglarna, som vid ifrågavarande muskels kontraktion stöda skulder- 
partiet i sitt läge och förhindra dess dragning emot bröstbenet och isynnerhet emot bröstbenskammen. Da allt i naturen utan tvifvel är inrättadt på det ändamålsenligaste sätt, tro vi äfven att styrkan af nyckelbenen hos representanterua af denna djurklass står $\mathrm{i}$ ett lämpligt förhållande till den kraft, med hvilken musculus pectoralis major verkar i deras riktning på öfverarmbenet, och att man således genom beräknande af den relativa styrkan af dessa ben hos skilda fogelarter bör erhålla värden, som motsvara den vid flygandet använda muskelstyrkan. För att beräkna styrkan af dessa ben, är det nödvändigt att uppmäta deras längd, bredd och tjocklek. Längden hafva vi uppmätt från den främsta ändan af tuberositas furcularis ända till den vanligen något framstående vinkel af nyckelbenen, som är belägen vid yttre kanten af incisura eller cavitas clavicularis på främre sidan af bröstbenet; bredden hafva vi bestämt efter det smalaste stället, emedan benet här lättast kan afbrytas, och uppmätt tjockleken på samma ställe, för att härigenom kunna beräkna genomskärningens yta.

Vanligen anser man storleken af den vinkel, som bildas af gaffelbenets bågar med hvarandra, stå i ett direkt förhållande till flygförmågan hos skilda fogelarter, och det kan icke förnckas, att åtminstone flere species, som utmärka sig genom en lätt och uthållande flygt, hafva denna vinkel ganska stor, dåliga flygare deremot proportionsvis temmeligen liten. Såsom vi ofvanföre omnämnt, utgår en del (den främsta sidan) af musculus pectoralis major ifrån ligamentum interclaviculare och ifrån gaffelbenet; styrkan af detta ben måste derföre i sjelfva verket stå i ett visst förhållande till den vinkel bågarna bilda med hvarandra, och i allmänhet blifva större, ju mera dessa bågar ligga i samma riktning med sjelfva muskeln. Då gaffelbenet emellertid, såsom vi sett, uppkommer genom en ossifikation i ligamentum interclaviculare och derföre äfven antager formen af detta ligaments äfrensom af bröstbenets framsida, som till skapnaden är mycket olika inom skilda grupper, 
kan vinkeln emellan gaffelbenets bågar åtminstone ej begagnas såsom ett allmänt mått för bestämmandet af den relativa flygförmågan hos species, som tillhöra isynnerhet något afvikande grupper. Såsom ett bevis för detta vårt påstående, skola vi här endast anföra, det vinkeln emellan bågarna af gaffelbenet hos tranan, som utmärker sig genom en temmeligen lätt flygt, är endast omkring $45^{\circ}$, då den deremot hos den tama hönan är af omkring 55 graders storlek. Men äfven för affina arter torde användandet af ifrågavarande vinkel såsom mått på den relativa flygförmågan icke kunna förordas, emedan det är ytterst svårt att på ett uppställdt skelett med större noggrannhet uppmäta densamma. Bågarna äro nemligen icke likformigt böjda öfver deras hela utsträckning och sjelfva spetsen af vinkeln stundom t. o. m. inåtböjd. Ehuru vi endast approximativt kunnat uppskatta storleken af clenna vinkel, hafva vi likväl ansett det nödigt att anföra resultaterna af dessa uppmätningar, emedan desamma kunna tjena åtminstone som bevis för vårt påstående, att den relativa storleken af förenämnda vinkel i allmänhet icke kan anses som ett mått på skilda arters flygförmåga. - Största af'ståndet mellan bågarna af gaffelbenet motsvarar i de flesta fall skulderpartiernas afstind från hvarandra; för att åtminstone gifva en föreställning om dessa partiers inbördes läge, hafva vi på gaffelbenet af alla exemplar tillika uppmätt förenämnda afstånd.

Alla öfriga uppmätningar, som af oss blifvit utförda; tjena endast till att närmare bestämma bröstbenets dimensioner och form. Längden af detta ben är enligt regel uppmätt på den öfre, d. v. s. den emot kroppens inre delar vända sidan, från främre kanten emellan nyckelbenen ända till slutet af den mellersta delen. I längden af sternum hafva vi likväl ej inberäknat det stundom förgrenade utskott (spina sternalis), som förekommer hos åtskilliga foglar vid bröstbenets framsida, emedan detsamma tjenar hvarken till underlag för kroppens inre organer, ej heller 
som fäste för musculus pectoralis major. - Enedan fästet af nyssnämnda muskel exempelvis hos roffoglarna sträcker sig på bakre delen af bröstbenet endast så lüngt som bröstbenskammen räcker, hafva vi ansett det nödigt att särskildt uppmäta längden af crista sterni. I sådana fall, då bröstbenets kam baktill småningom - och i början nästan omärkligt - höjer sig öfver sterni utplattade del, är detta längdmått något osäkert.

Hos flere fogelarter är den främsta ändan af crista sterni något nedåtböjd emot bröstbenets framsida; vi hafva derföre ej allenast uppgifvit bröstbenskammens största höjd, utan äfven dess höjd vid främre kanten. D̊̊ bröstbenets yta svårligen kan på ett likformigt sätt bedömmas efter dess största bredd, emedan vid främre sidan af detta ben inom somliga grupper förekomma egendomliga utskott eller bihang, som saknas hos andra, hafva vi ansett det ändamålsenligare att uppmäta den minsta bredden af sternum. Härvid måste likväl anmärkas, att den minsta bredden af ifrågavarande ben inom skilda grupper icke infaller på samma ställe: oftast är sternum máhända smalast emellan det andra och tredje paret af ossa sterno-costalia, stundom bakoin det sista; men i alla händelser lemnar, såsom redan nämndes, en måtbestämning öfver minsta bredden af bröstbenet en säkrare grund för bedömmandet af dess yta, än uppgiften öfver len största bredden.

Af bröstbenets diniensioner äfvensom af bröstbenskammens höjl och utsträckning beror naturligtvis i väsendtligaste mån storleken af den vidfästningrsyta, på hvilken musculus pectoralis major utbreder sig, och dì pâ bakre cidan af brösthencts utplattade eller mera horizontala del förekomma större eller nindre hål eller utskärningar, måste dessa átminstone till nảgon grad minska styrkan af förenïmnda muskel. Väl betvifla ri, att man genom bestämningar öfver bröstbenets dimensioner kan vinna en lika säker grund för bedönmandet af den virl utförandet af vingrslagen använda muskelstyrkan hos skilda arter som genom 
beräknandet af nyckelbenens styrka, men hafva dock ansett det nödvändigt att åtminstone ungefärligen uppge storleken af dessa hål eller utskärningar, emedan desamma äro åtminstone betydligt större hos sådana foglar, hvilka icke utmärka sig genom en snabb eller lätt flygt, och saknas stundom alldeles hos utmärkta flygare.

Valet af arter, som blifvit uppmätta, har naturligtvis icke varit alldeles fritt, utan beroende af tillgångarna på härvarande anatomiska museum. Med undantag af några få species, som äro allmänt kända antingen för sin utmärkta flygförmåga eller totala brist derpå, hafva vi nästan uteslutande utvalt sådana former, som förekomma $i$ vårt land och hvilkas flygt således af oss bäst kan bedömmas. Inom några slägten och grupper hade valet af arter visserligen utfallit annorlunda, om vi ej varit nödsakade att fästa afseende vid de uppmätta exemplarens fullständighet.

Vi hafva vid ett föregående tillfälle uttalat vårt ogillande af det nog allmänt använda förfarandet att förändra flere af de af LINNÉ gifna artnamnen och i stället begagna dem som generiska benämningar. Di vi likväl här följa den vanligen begagnade nomenklaturen, sker det ingalunda af något slags medgifvande, att denna method vore riktig, utan endast tillfölje deraf, att vi anse det olämpligt att här i ett arbete, som har ett helt annat syfte; rätta några få benämningar, då det vore i högsta grad nödvändigt, att hela den ornithologiska nomenklaturen samtidigt skulle underkastas en fuliständig revision. Alla artnamn hafva vi skrifvit med små initialbokstäfver, såsom man i sednare tider med allt skäl brukat göra $\mathrm{i}$ fråga om flere andra djurklasser.

Enligt de grunder här ofvan blifvit framställda hafva vi uppmätt omkring ett hundra fogelarter och gå nu att meddela resultaterna af dessa mätningar, hvilka tjena till material för de längre fram utförda beräkningarna. 
1) Ilirundo rustica L. - (Uskela - ppt. E. J. B.)*)

Längden af os humeri . . . . . . 13,8 m.m.

$" \quad n \ln a$............ . . 24,0

$" \quad$ benen i carpus ........ . . 1,2 ?

" metacarpus ......... . 13,5 "

" mellanfingrets 1 :sta led .... 9,5 \%

" $" 2:$ dra $\gg . . .55,3 \%$

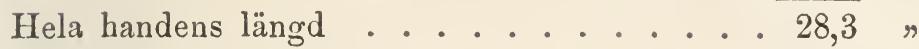

Afståndet från 1:sta bröstkotan till os coccygis 38,4 ,

Längden af clavicula . . . . . . . 15,0 " . . . .

Minsta bredden af clavicula ...... . . 1,2 "

Tjockleken $\gg$. . . . . . . 1,2

Vinkeln emellan bågarna af furcula . . . . $100^{\circ}$ ?

Största afståndet mellan bågarna af furcula . . 4,0 m.m.

Längden af sternum . . . . . . . . 17,0 n

Minsta bredden af sternum . . . . . . 10,5 ,

(Största " " baktill ... . 15,0 ")

Längden af crista sterni . . . . . . 17,5 "

Största höjden af crista sterni. . . . . 6, 6, " .

Höjden af crista sterni framtill . . . . . 6,4

Längden af incisura sterni (ossifierad) . . . 6,0 "

Största bredden af incisura sterni .. . . . 3,5 "

2) Chelidon urbica L. - (ㅇ, Uskela - d.d. J. v. Wright.)

Längden af os humeri . . . . . . 13,2 m.m.

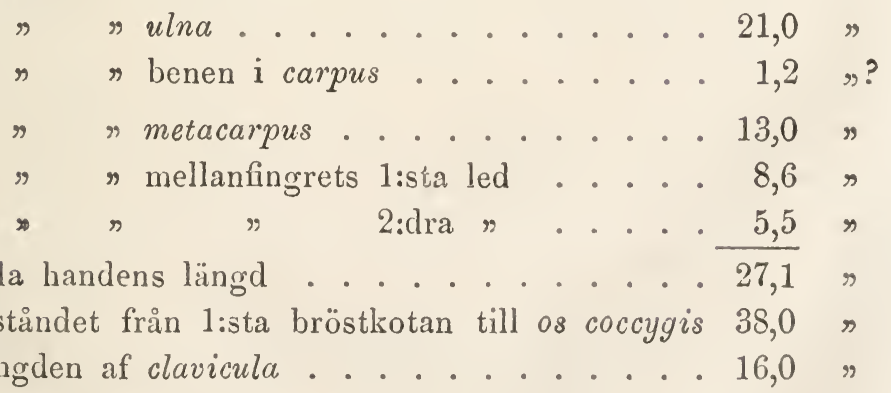

*) För att bestämdare utpeka de uppmätta exemplaren i samlingen, hafra vi efter etiketterna afskrifvit uppgiften öfver fundort, m. m. 
Minsta bredden af clavicula $1,2 \mathrm{~m} . \mathrm{m}$. Tjockleken

Vinkeln emellan bågarna af furcula 1,2 \% Största afståndet mellan bågarna af furcula . . 5,0 m.m. Längden af sternum 15,0 \%

Minsta bredden af sternum

(Största $" \quad$ baktill ..... 15,0

Längden af crista sterni . . . . . . . . 14,0 \%

Största höjden af crista sterni. . . . . . 6, 6,6

Höjden af crista sterni framtill . . . . . 6, 6, . .

Längden af incisura sterni (ossifierad) . . . 6,7

Största bredden af incisura sterni . . . . . 3,5 \%

3) Monedula turrium Brehm. (Corrus monedula L.) - (Aboae.)

Längden af os humeri . . . . . . . 4 46,0 m.m.

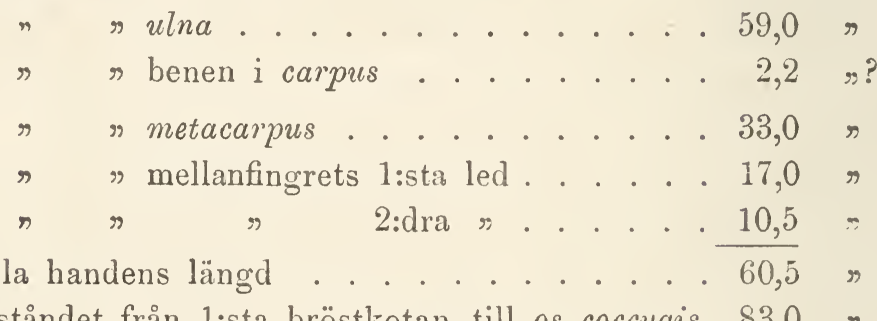

Afståndet från 1:sta bröstkotan till os coccygis 83,0 ᄁ

Längden af clavicula . . . . . . . . 32,5 "

Minsta bredden af clavicula ....... . 2,4

Tjockleken $\gg \quad$. . . . . . . 2, 2,6 \%

Vinkeln emellan bågarna af furcula . . . . . $100^{\circ}$ ?

Största afståndet mellan bågarna af furcula . . 15,0 m.m.

Längden af sternum . . . . . . . . 37,5 " . . . .

Minsta bredden af sternum . . . . . . . 20,5 " . .

Längden af crista sterni . . . . . . . . 3 3,4, .

Största höjden af crista sterni . . . . . . 14,0 \%

Höjlen af crista sterni framtill . . . . . . . 14,0 "

Länden af incisura sterni . . . . . . . . 13,0 »

Största bredden af incisura sterni . . . . . 6 6.0

4) Corrus corax L. - (Helsinge - d.d. Hirn.)

Längden af os humeri . . . . . . . 90,0 m.m. 
Längden af ulna

109,0 m.m.

(1)

" benen i carpus

$5,0 \quad \cdots$ ?

" metacarpus

59,0 भ

2)

\% mellanfingrets 1:sta led.

31,5 r

,

"

2:dra

- 19,5 r

Hela bandens längd .

110,0 \%

Afștåndet från 1:sta bröstkotan till os coccygis 147,0 n

Längden af clavicula

56,0 ᄁ

Minsta bredden af clavicula

4,5 भ

Tjockleken

"

$4,7 \%$

Vinkeln emellan bågarna af furcula

$105^{\circ}$ ?

Största afståndet mellan bågarna af furcula

$30,0 \mathrm{~m} \cdot \mathrm{m}$.

Längden af sternum

65,0 r

Minsta bredden af sternum

37,0 \%

Längden af crista sterni

60,0 r

Största höjden af crista sterni . . . . . . 21,0 \%

Höjden af crista sterni framtill . . . . . 20,0 n

Längden af incisura sterni . . . . . . . 13,2 "

Största bredden af incisura sterni . . . . . 6, 6,5

5) Corrus cornix L. - (Uskela.)

Längden af os humeri

73,0 m.m.

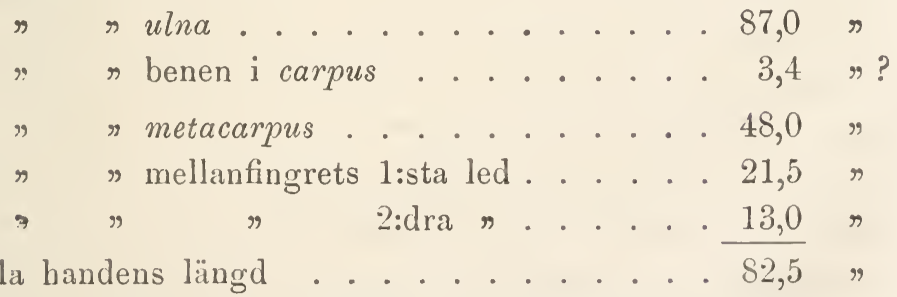

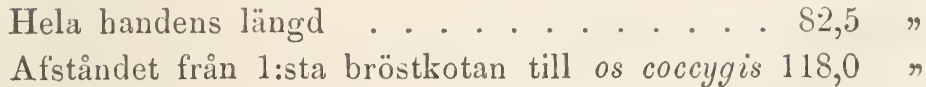

Längden af clavicula . . . . . . . . 4 45,0 " . . .

Minsta bredden af clavicula . . . . . 3,7

Tjockleken

"

Vinkeln emellan bågarna af furcula . . . . $105^{\circ}$ ?

Största afståndet mellan bågarna af furcula . . 23,0 m.m.

Längden af sternum

$52,0 \quad \%$

Minsta bredden af sternum

29,0 , 
Längden af crista sterni . . . . . 51,0 m.m. Största höjden af crista sterni. . . . . 18,5 " Höjden af crista sterni framtill . . . . . 15,0 " Längden af incisura sterni . . . . . . 14,0 " Största bredden af incisura sterni . . . . 8,0

6) Pica caudata L. - ( $\sigma^{\prime}$, Uskela - ppt. E. J. B.)

Längden af os humeri . . . . . . 45,0 m.m.

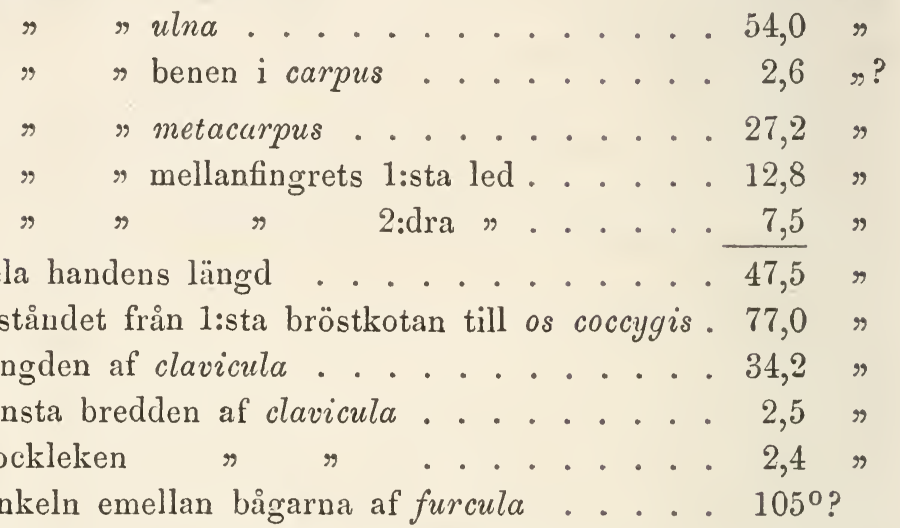

Största afståndet mellan bågarna af furcula . . 17,7 m.m. Längden af sternum . . . . . . . 35,0 " Minsta bredden af sternum . . . . . 21,0 " Längden af crista sterni . . . . . . 36,4" Största höjden af crista sterni . . . . 12,0 " Höjden af crista sterni framtill . . . . . 11,5 " Längden af incisura sterni . . . . . . 12,0 " Största bredden af incisura sterni . . . . 7, 7,0 "

7) Garrulus glandarius L. - (Uskela - ppt. E. J. B.)

Längden af os humeri . . . . . . 40,0 m.m.

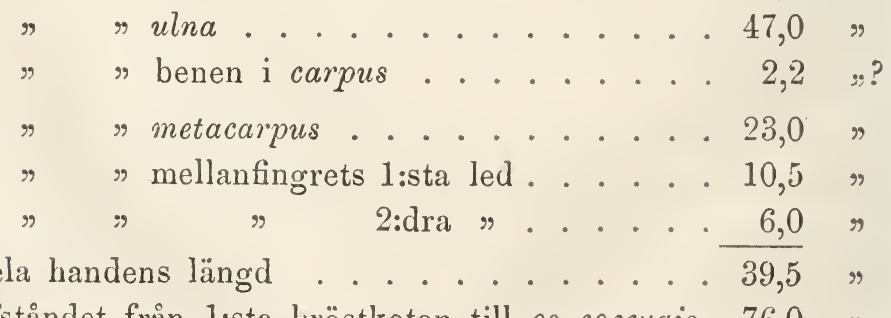

Afståndet från 1:sta bröstkotan till os coccygis 76,0 " 
Längden af clavicula

28,8 m.m.

Minsta bredden af clavicula

2,0 \%

Tjockleken

$"$

$2,2 \%$

Vinkeln emellan bågarna af furcula

$60^{\circ}$ ?

Största afståndet mellan bågarna af furcula . . 10,0 m.m.

Längden af sternum . . . . . . . 31,0 " . . . .

Minsta bredden af sternum . . . . . 17,0 "

Längden af crista sterni . . . . . . 29,5 "

Största höjden af crista sterni . . . . . . 10,0

Höjden af crista sterni framtill . . . . . 10,0 " . . .

Längden af incisura sterni . . . . . . . 9, 9, . . . . .

Största bredden af incisura sterni . . . . . 6,0

8) Turdus pilaris L. - (Helsingf. - ppt. Hacklin.)

Längden af os humeri . . . . . . . 29,5 m.m.

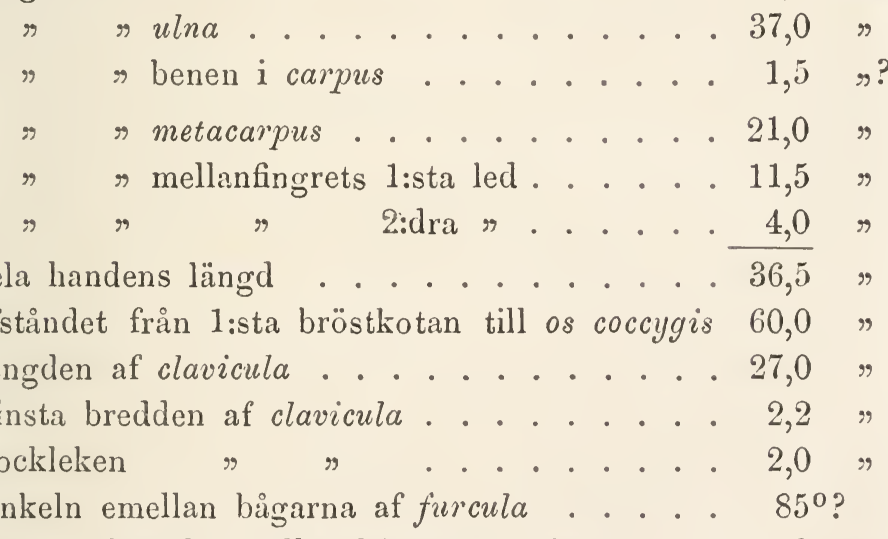

Största afståndet mellan bi̊garna af furcula . . 11,3 m.m.

Längden af sternum

Minsta bredden af sternum . . . . . . 15,5 "

Längden af crista sterni . . . . . . . 30,5 " . . . . .

Största höjden af crista sterni . . . . . 11,0 "

Höjden af crista sterni framtill . . . . . 11,0 "

Längden af incisura sterni . . . . . . 12,0 "

Största bredden af incisura sterni . . . . . 6,5 "

9) Ampelis garrulus L. - (Helsinge - ppt. E. J. B.)

Längden af os humeri . . . . . . . 23,2 m.m. 
Längden af $u \ln \alpha$ 30,5 m.m.

" $\quad$ benen $\mathrm{i}$ carpus

$1,3 \quad n$ ?

" metacarpus

16,2 r

" mellanfingrets 1:sta led

$9,0 \%$

$m \quad$

" 2:dra

$3,6 \%$

Hela handens längd

28,8 \%

Afstảndet från 1:sta bröstkotan till os coccygis 57,0 \%

Längden af clavicula ......... . 24,0 \%

Minsta bredden af clavicula . . . . . . 1,7

Tjockleken $"$ ". . . . . . 1,8 1,8

Vinkeln emellan bågarna af furcula . . . . $100^{\circ}$ ?

Största afståndet mellan bågarna af furcula . . 6,7 m.m.

Längden af sternum . . . . . . . 24,0 \%

Minsta bredden af sternum ...... . . 15,0 \%

Längden af crista sterni . . . . . . . 24,0 "

Största höjden af crista sterni . . . . . . 11,0 \%

Höjden af crista sterni framtill (framom sternum) 12,0 „?

Längden af incisura sterni . . . . . . . 11,0"

Största bredden af incisura sterni . . . . . 5,0 \%

10) Pinicola enucleator L. - (Nyland. - ppt. E. J. B.)

Längden af os humeri . . . . . . . 23,4 m.m.

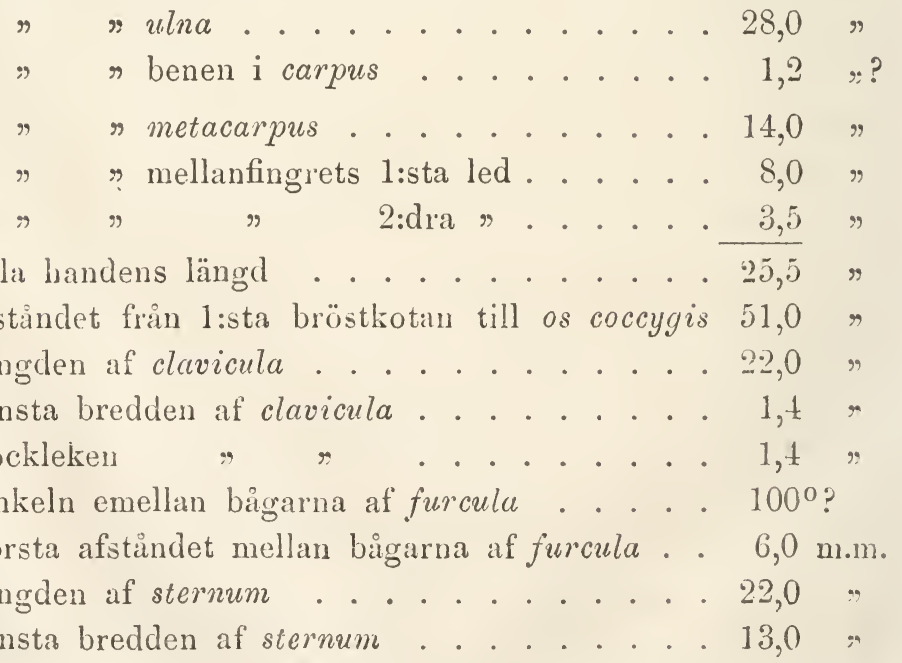


Längden af crista sterni

22,0 m.m.

Största höjden af crista sterni

9,0 \%

Höjden af crista sterni framtill

$8,5 \rightarrow$

Längden af incisura sterni . . . . . . 10,5 \%

Största bredden af incisura sterni . . . . . . 4,6

11) Cuculus canorus L. - ( $\sigma^{7}$, Lskela - ppt. E. J. B.)

Längden af os humeri . . . . . . . 41,0 m.m.

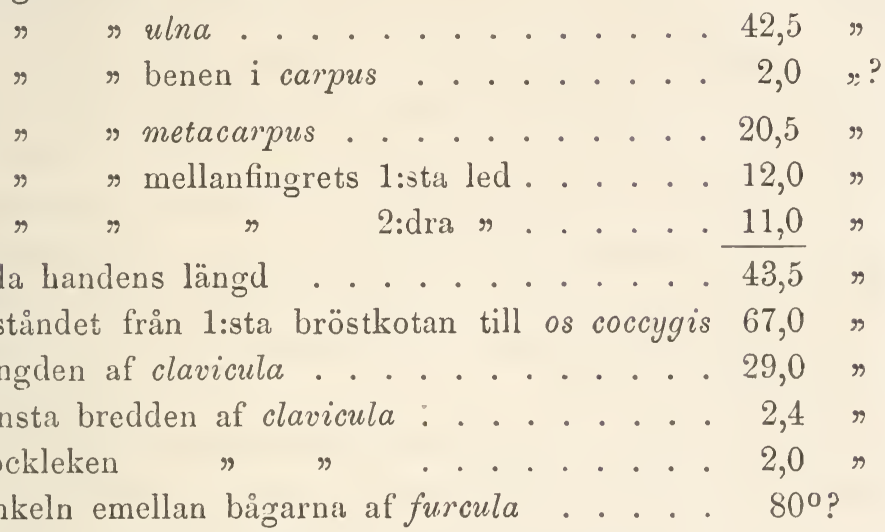

Största afståndet mellan bågarna af furcula . . 11,0 m.m. Längden af sternum . . . . . . . . 34,0 "

Minsta bredden af sternum . . . . . . 17,5 "

Längden af crista sterni . . . . . . . 31,5 "

Största höjden af crista sterni . . . . . 13,0 »

Höjden af crista sterni framtill . . . . . . 12,0

Längden af incisura sterni . . . . . . 5, 5, . .

Största bredden af incisura sterni . . . . . 2,3

12) Dryocopus martius L. - (Uskela.)

Längden af os humeri . . . . . . . 54,0 m.m.

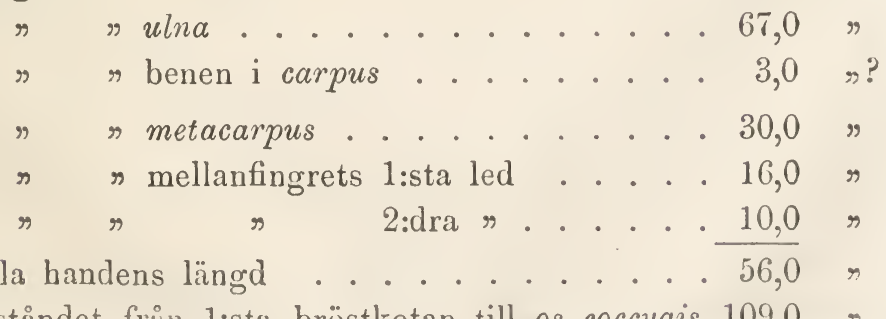

Afståndet från 1:sta bröstkotan till os coccygis 109,0 \# 
Längden af clavicula 42,0 m.m.

Minsta bredden af clavicula

3,2 ᄁ

Tjockleken

Vinkeln emellan bågarna af furcula

3,2 "

$70^{\circ}$ ?

Största afståndet mellan bågarna af furcula . . 22,0

Längden af sternum . . . . . . . 4 43,0

Minsta bredden af sternum . . . . . 19,0

Längden af crista sterni . . . . . . . 46,0 " . . . .

Största höjden af crista sterni. . . . . . 15,0

Höjden af crista sterni framtill . . . . . . 15,0

Längden af incisura sterni exterior . . . 8, 8,0 \%

Största bredden af incisura sterni exterior . . 5,0 "

Längden af incisura sterni interior . . . . . 11,0 \%

Största bredden af incisura sterni interior . . 3,0 "

13) Gecinus canus Gmel. - (L'skela.)

Längden af os humeri . . . . . . 37,0 m.m.

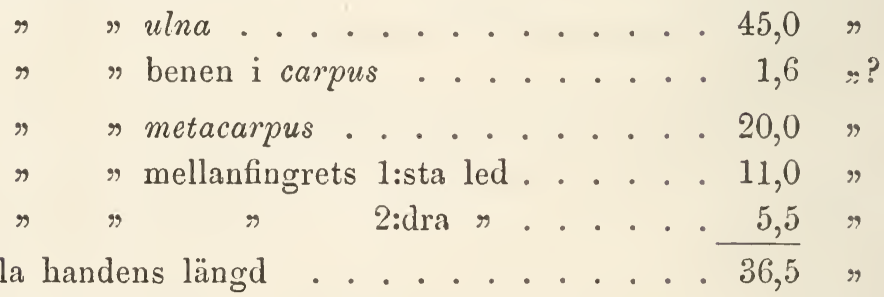

Afståndet från 1:sta bröstkotan till os coccygis 77,0 "

Längden af clavicula . . . . . . . 31,0"

Minsta bredden af clavicula ....... . 2,3 " . . . .

Tjockleken $"$ " . . . . . 2, $2,2 \%$

Vinkeln emellan bågarna af furcula . . . . $70^{\circ}$ ?

Största afståndet mellan bågarna af furcula . 12,5 m.m.

Längden af sternum . . . . . . . 30,0 " . . . .

Minsta bredden af sternum ...... . . 15,5 \%

Längden af crista sterni . . . . . . . 34,5 \%

Största höjden af crista sterni. . . . . . 10,5\%) ?

Höjden af crista sterni framtill (framom sternum) 15,0 „?

*) Största höjden af bröstbenskammen är alltid uppmätt ifrån den horizontala delen af bröstbęnet. 
Längden af incisura sterni exterior

$8,5 \mathrm{~m} \cdot \mathrm{m}$.

Största bredden af incisura sterni exterior . . 2,5

Längden af incisura sterni interior . . . . 9, 9,0 "

Största bredden af incisura sterni interior . . 4,2 \%

14) Gecinus viridis L. - (ㅇ, Srecia - d. Sundevall.)

Längden af os humeri . . . . . . . 43,0 m.m.

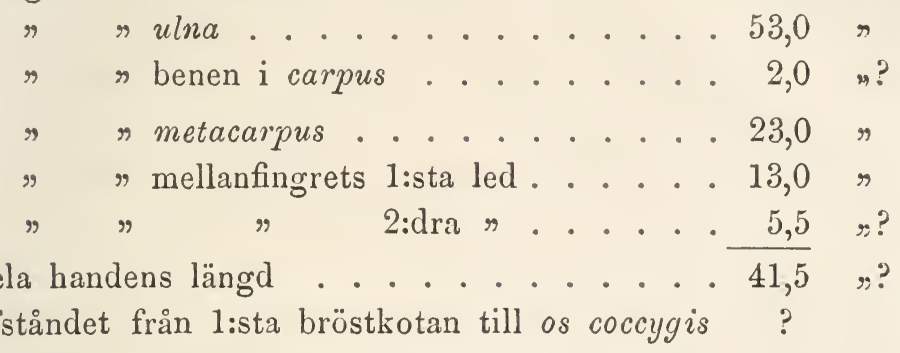

Längden af clavicula . . . . . . . 38,0 m.m.

Minsta bredden af clavicula . . . . . . 2,5 \%

Tjockleken " . . . . . . . 2,4

Vinkeln emellan bågarna af furcula . . . . $80^{\circ}$ ?

Största afståndet mellan bågarna af furcula . . 18,0 m.m.

Längden af sternum . . . . . . . . 35,0 \%

Minsta bredden af sternum . . . . . 17,0

Längden af crista sterni . . . . . . 39,0 "

Största höjden af crista sterni . . . . . 12,0

Höjden af crista sterni framtill (framom sternum) 15,0

Längden af incisura sterni exterior . . . . 8,0 \%

Största bredden af incisura sterni exterior . . 3,5 \%

Längden af incisura sterni interior . . . . 10,0

Största bredden af incisura sterni interior . . 4,5

15) Picus medius L. - (Germania - ppt. Hacklin.)

Längden af os humeri . . . . . . 32,0 m.m.

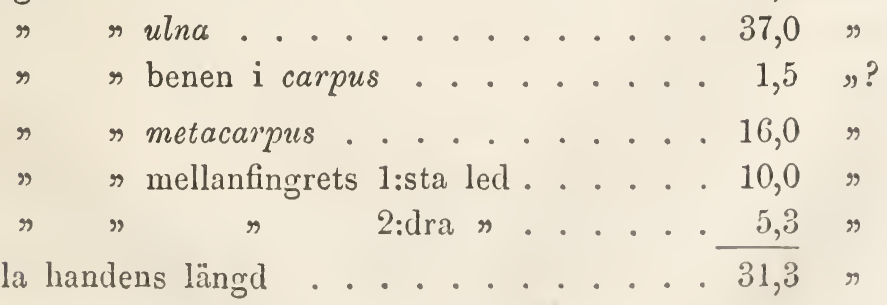

Hela handens längd 
Afståndet från 1:sta bröstkotan till os coccygis 64,0 m.m.

Längden af clavicula

Minsta bredden af clavicula

27,0 \%

Tjockleken

1,6 \%

Vinkeln emellan bågarna af furcula

2,0 \%

$50^{\circ}$ ?

Största afståndet mellan bågarna af furcula . . 7,5 m.m.

Längden af sternum

27,0 \%

Minsta bredden af sternum ...... 10,6 n

Längden af crista sterni ... . . . . . 30,0 "

Största höjden af crista sterni . . . . . 10,4 "

Höjden af crista sterni framtill (framom sternum) 13,5 "

Längden af incisura sterni exterior . . . . 7,5

Största bredden af incisura sterni exterior . . 3,0 "

Längden af incisura sterni interior . . . . . 9,5 "

Största bredden af incisura sterni interior . . 3,2 "

16) Picus lcuconotus Bechst. - (o', Uskela.)

Längden af os humeri . . . . . 36,5 m.m.

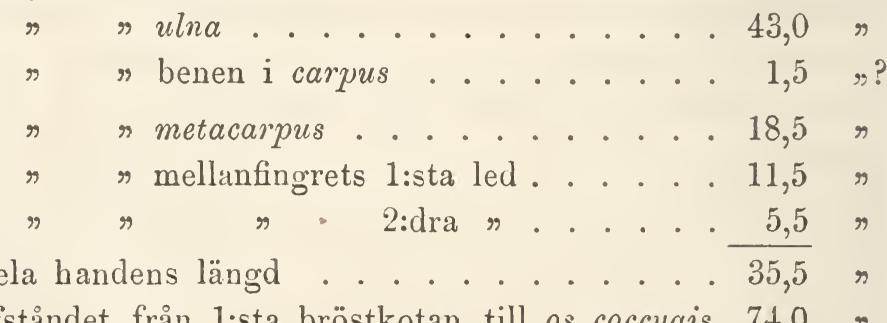

Afståndet från 1:sta bröstkotan till os coccygis 74,0 , Längden af clavicula ........ 31,0

Minsta bredden af clavicula....... 1,8

Tjockleken $\quad$ " ........ 2,5 "

Vinkeln emellan bågarna af furcula . . . 6 $60^{\circ}$ ?

Största afståndet mellan bågarna af furcula . . 12,0 m.m.

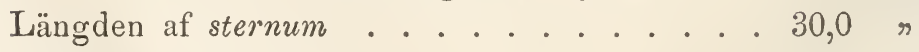

Minsta bredden af sternum ..... 13,0

Längden af crista sterni ... . . . . . 33,0 "

Största höjden af crista sterni . . . . . 12,0 "

Höjden af crista sterni framtill (framom sternum) 15,6 "?

Längden af incisura sterni exterior . . . . 9,0 " 
Största bredden af incisura sterni exterior . . 5,0 m.m.

Längden af incisura sterni interior .... 9, 9,5

Största bredden af incisura sterni interior . . 4,0 "

17) Picus major L. - (Q9, Helsingf. 1859.)

Längden af os humeri . . . . . 33,0 m.m.

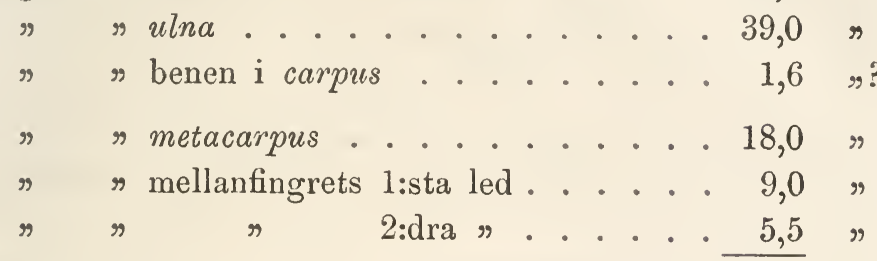

Hela handens längd ........ . . 32,5 \%

Afståndet från 1:sta bröstkotan till os coccygis 68,5 *) \#?

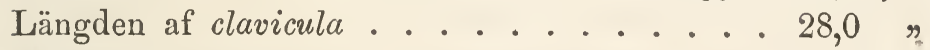

Minsta bredden af clavicula ...... 2, 2, ”

Tjockleken $\quad$ " ........ 2, 2,

Vinkeln emellan bågarna af furcula . . . $65^{\circ}$ ?

Största afståndet mellan bågarna af furcula . . 10,0 m.m.

Längden af sternum . . . . . . 27,0 " . . 2

Minsta bredden af sternum . . . . . 13,0 "

Längden af crista sterni . . . . . . 30,0 "

Största höjden af crista sterni . . . . . 10,5 "

Höjden af crista sterni framtill (framom sternum) 12,5 "

Längden af incisura sterni exterior . . . . 8,0 "

Största bredden af incisura sterni exterior . . 3,2 "

Längden af incisura sterni interior . . . . 8,0 "

Största bredden af incisura sterni interior . . 4,0

18) Picus minor L. - (Helsinge - ppt. E. J. B.)

Längden af os humeri . . . . . 21,0 m.m.

$" \quad "$ ulna . . . . . . . . . . . . . 25,0 . 1,0 ?

*) Emedan tvenne svanskotor saknas, är detta afstând approximativt beräknadt efter ett annat exemplar af denna art.

(F. W. M-n V. 1867.) 
Längden af metacarpus

10,0 m.m.

\%

"mellanfingrets 1:sta led.

7,0 \%

$\eta \quad "$

$"$

2:dra $\%$

Hela handens längd

Afståndet från 1:sta bröstkotan till os coccygis 43,5 "

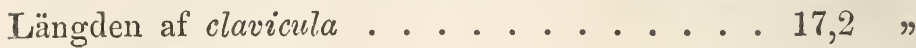

Minsta bredden af clavicula ...... . . 1,2 " . .

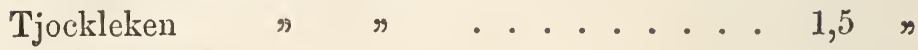

Vinkeln emellan bågarna af furcula . . . $60^{\circ}$ ?

Största afståndet mellan bågarna af furcula . . 4,0 m.m.

Längden af sternum

17,2 \%?

Minsta bredden af sternum ...... . 8,0 "

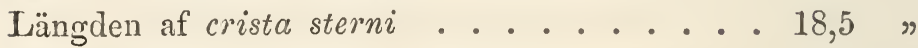

Största höjden af crista sterni . . . . . 6,5

Höjden af crista sterni framtill (framom sternum) 8,5 \%

Längden uf incisura sterni exterior . . . . 7,0 "

Största bredden af incisura sterni exterior . . 3,0 \%

Längden af incisura sterni interior . . . 5, 5,0

Största bredden af incisura sterni interior . . 2,0

19) Apternus tridactylis L. - (Cskela - ppt. E. J. B.)

Iängden af os humeri . . . . . . 30,0 m.m.

" sulna ............... 34,0 . $"$

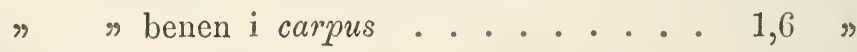

" metacarpus ........ 15,0

" mellanfingrets 1:sta led .... 9, 9,0 "

" $" 2:$ dra $\%$.... 4,0 \%

Hela handens längd . . . . . . . . 28,0 "

Afståndet från 1:sta bröstkotan till os coccygis 61,0 "

Längden af clavicula . . . . . . . 26,0 " . . . .

Minsta bredden af clavicula ...... . . 1,6

Tjockleken $\quad$ " ........ 2, 2,0 \%

Vinkeln emellan bågarna af furcula . . . . $55^{\circ}$ ?

Största afståndet mellan bågarna af furcula . - 6,5 m.m.

Längden af sternum ........ 24,0

Minsta bredden af sternum ....... 9, 9,5 " 
Längden af crista sterni . . . . . . 26,5 m.m. Största höjden af crista sterni . . . . . 10,0 "

Höjden af crista sterni framtill (framom sternum) 11,0 " Längden af incisura sterni exterior . . . . 7,0 " Största bredden af incisura sterni exterior . . 4,0 " Längden af incisura sterni interior . . . . 8,2 " Största bredden af incisura sterni interior . . 3,2 "

20) Cypselus apus L. - (Uskela - ppt. E. J. B.)

Längden af os hrmeri . . . . . . . 11,0 m.m.

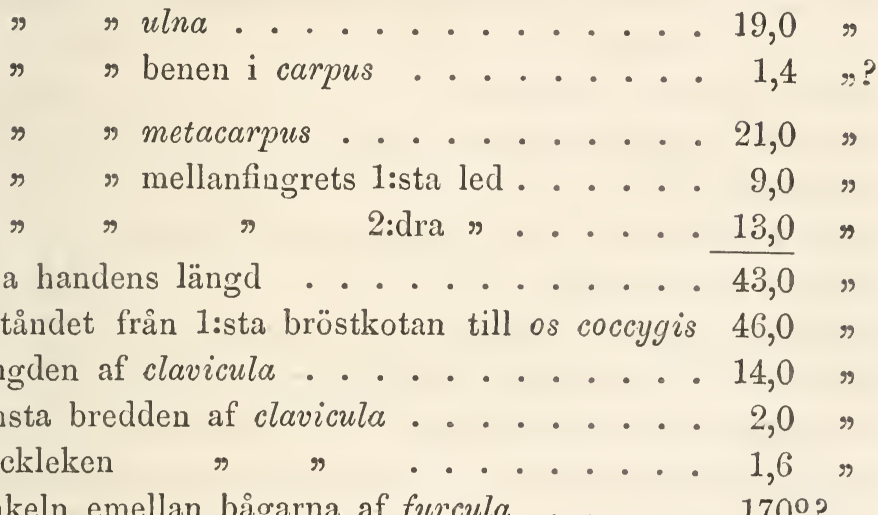

Vinkeln emellan bågarna af furcula . . . 170 ?

Största afståndet mellan bågarna af furcula . . 7,5 m.m. Längden af sternun . . . . . . . 24,0 " . . Minsta bredden af sternum . . . . . . 9,0 (Största bredden af sternum baktill . . . . 18,0 Längden af crista sterni . . . . . . 27,0 \% Största höjden af crista sterni . . . . . 13,6 " Höjden af crista sterni framtill . . . . . 13,0 \% Längden af incisura sterni . . . . . . 0,0 0,0 , Största bredden af incisura sterni . . . . 0,0

21) Cypselus apus L. - (Uskela - ppt. E. J. B.)

Längden af os humeri . . . . . . 11,5 m.m.
")
$\Rightarrow u \ln a$. . . . . . . . 19,4 " . . . .
9)
$\rightarrow$ benen i carpus
1,5 ᄁ 
Längden af metacarpus

$20,5 \mathrm{~m} . \mathrm{m}$.

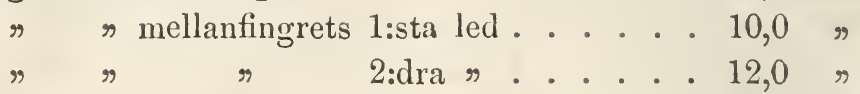

Hela handens längd ... . . . . . $\overline{42,5}$ "

Afståndet från 1:sta bröstkotan till os coccygis 47,0 "

Längden af clavicula . . . . . . 14,0 "

Minsta bredden af clavicula ...... 1,9 "

Tjockleken $\quad$ " ......... 1,6

Vinkeln emellan bågarna af furcula . . . $170^{\circ}$ ?

Största afståndet mellan bågarna af furcula . . 7,6 m.m.

Längden af sternum . . . . . . 24,0 "

Minsta bredden af sternum ...... 9 9,5 \%

(Största bredden af sternum baktill . . . . 17,0 $\%$ )

Längden af crista sterni ...... 26,0

Största höjden af crista sterni . . . . . 13,0 "

Höjden af crista sterni framtill . . . . 12,0 "

Längden af incisura sterni ....... 0. 0,0 ".

Största bredden af incisura sterni .... 0,0

22) Hypermetra (Trochilus) gigas Vieill. - (Ded. D:r Sahlberg.)

Längden af os humeri . . . . . . 10,0 m.m.

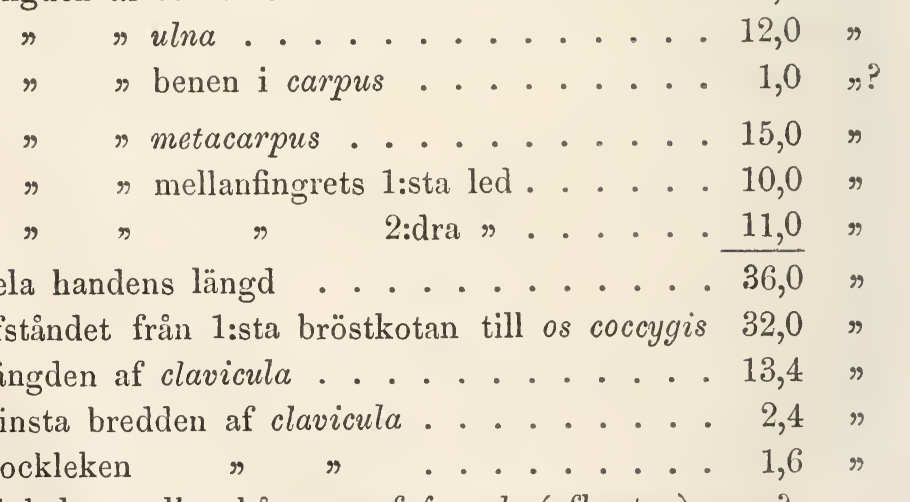

Vinkeln emellan bågarna af furcula (afbruten). ?

Största afståndet mellan bågarna af furcula . . ?

Längden af sternum . . . . . . . 30,0 m.m.?

Minsta bredden af sternum ...... 7,0 "

Längden af crista sterni ... . . . 30,0 
Största höjden af crista sterni . . . . . . 14,5 m.m. Höjden af crista sterni framtill . . . . . 9, 9, Längden af incisura sterni . . . . . . 0,0 Största bredden af incisura sterni . . . . . 0 0,0

23) Caprimulgus europaeus L. - (Uskela - ppt. E. J. B.)

Längden af os humeri . . . . . . . 38,0 m.m.

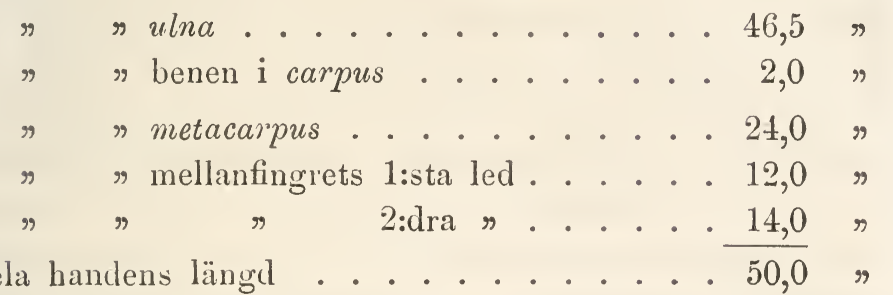

Afståndet från 1:sta bröstkotan till os coccygis 51,0 " Längden af clavicula . . . . . . . 20,0 " . . . . Minsta bredden af clavicula ...... . 2, . . . . .

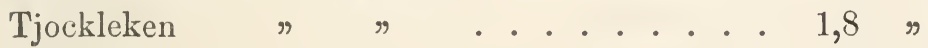
Vinkeln emellan bågarna af furcula . . . . $100^{\circ}$ ?

Största afståndet mellan bågarna af furcula . . 10,0 m.m. Längden af sternum . . . . . . . 26,0 " . . . . Minsta bredden af sternum . . . . . . 15,0 " . . . . . Längden af crista sterni . . . . . . . 26,0 " . . . (11,0 Största höjden af crista sterni . . . . . . 11,0 " Höjden af crista sterni framtill . . . . . 10,0 " . . . . . Längden af incisura sterni . . . . . . . 5,0 ” Största bredden af incisura sterni . . . . . 7,0 "

24) Pandion haliaëtus L. - (Uskela.)

Längden af os humeri . . . . . . . 139,0 m.m.

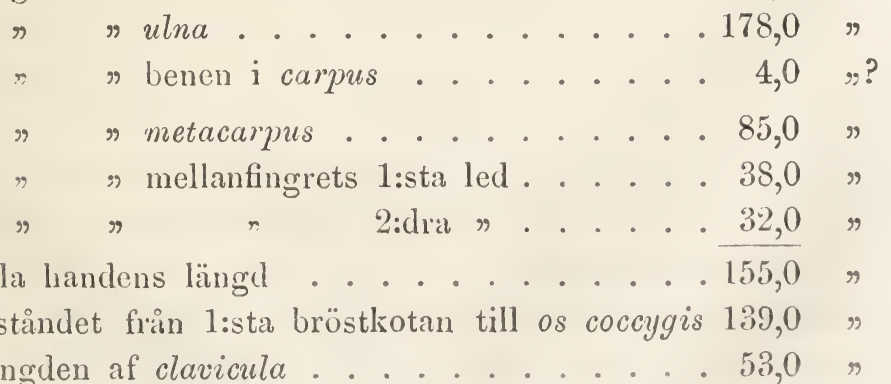

Längden af clavicula ........ . . 53,0 " 
Minsta bredden af clavicula ..... 8,0 m.m. Tjockleken $\quad " \ldots \ldots . . .5,0$,

Vinkeln emellan bågarna af furcula . . . 150 ?

Största afståndet mellan bågarna af furcula . . 39,0 m.m. Längden af sternum . . . . . . . 84,0 " Minsta bredden af sternum . . . . . 43,0 " Längden af crista sterni . . . . . . 65,0 ” Största höjden af crista sterni . . . . 25,0 ” Höjden af crista sterni framtill . . . . 20,0 " Af incisura sterni finnes endast en svag inböjning på baksidan af bröstbenet.

25) Milrus regalis Briss. (Falco milrus L.) - (Germania, Brandt.) Längden af os humeri . . . . . 125,0 m.m.

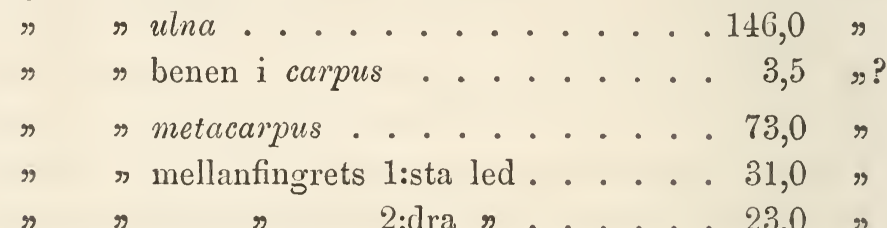

Hela handens längd . . . . . . . $\overline{127,0}$ ”

Afståndet från 1:sta bröstkotan till os coccygis 143,0 ” Längden af clavicula ....... 49,0 Minsta bredden af clavicula ...... . 7,0 " Tjockleken $\quad$ " $\quad \ldots \ldots \ldots . .55,6 \%$

Vinkeln emellan bågarna af furcula . . . $135^{\circ}$ ?

Största afståndet mellan bågarna af furcula . . 32,0 m.m. Längden af sternum . . . . . . 6 67,0 ” Minsta bredden af sternum . . . . . 4 41,0 " Längden af crista sterni ...... . . 54,0 Största höjden af crista sterni . . . . . 16,0 " Höjden af crista sterni framtill . . . . . 15,0 " Längden af foramen sterni . . . . . . 9, . Största bredden af foramen sterni . . . . 6, 6,0 "

26) Aquila chrysaëtus L. - (O'? Uskela.)

Längden af os humeri . . . . . . 198,0 m.m.

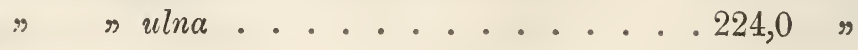


Längden af benen i carpus

$5,0 \mathrm{~m} . \mathrm{m}$.?

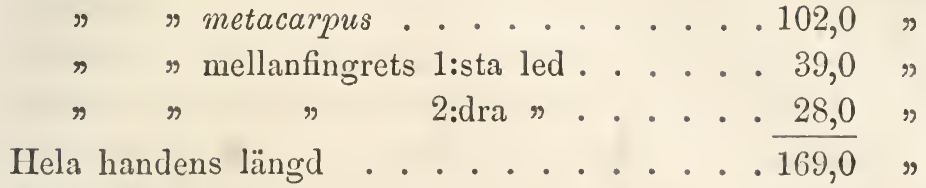

Afståndet från 1:sta bröstkotan till os coccygis 207,0 》

Längden af clavicula ....... 80,0 80 \%

Minsta bredden af clavicula ...... 14,0 "

Tjockleken

" $"$

9,5 m

Vinkeln emellan bågarna af furcula . . . $150^{\circ}$ ?

Största afståndet mellan bågarna af furcula . . 58,0 m.m.

Längden af sternum . . . . . . . 124,0 ”

Minsta bredden af sternum . . . . . 64,0 "

Längden af crista sterni ...... . 93,0 "

Största höjden af crista sterni . . . . 26,0 "

Höjden af crista sterni framtill . . . . 24,0

Längden af foramen sterni . . . . . 8,0

Största bredden af foramen sterni . . . . 6,0 "

27) Aquila chrysaëtus L. - ㅇ? (Helsinge.)

Längden af os humeri . . . . 210,0 m.m.

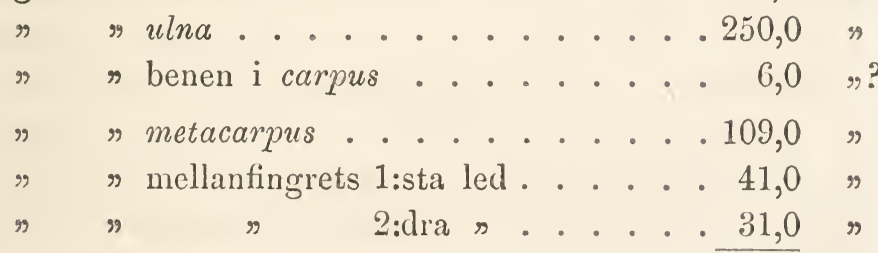

Hela handens längd . . . . . . . 181,0

Afstindet fri̊n 1:sta bröstkotan till os coccygis 245,0 \%

Längden af clavicula . . . . . . . 73,0 "

Minsta bredden af clavicula ...... 14,0 "

Tjockleken $\quad$ " $\quad \ldots . . .110,0$.

Vinkeln emellan bigarna af furcula . . . 165 ?

Största afståndet mellan biogarna af furcula . . 66,0 m.m.

Lüngden af sternum . . . . . . . 134,0 ”

Minsta bredden af sternum ..... . 69,0 "

Längden af crista sterni . . . . . 107,0 ” 
Största höjden af crista sterni. 28,0 m.m.

Höjden af crista sterni framtill

$$
26,0 \text { ?? }
$$

Längden af foramen sterni . . . . . . . 0,0 n

Största bredden af foramen sterni . . . . 0,0 \%

28) Haliaëtus albicilla L. - (Helsinge.)

Längden af os humeri . . . . . 236,0 m.m.

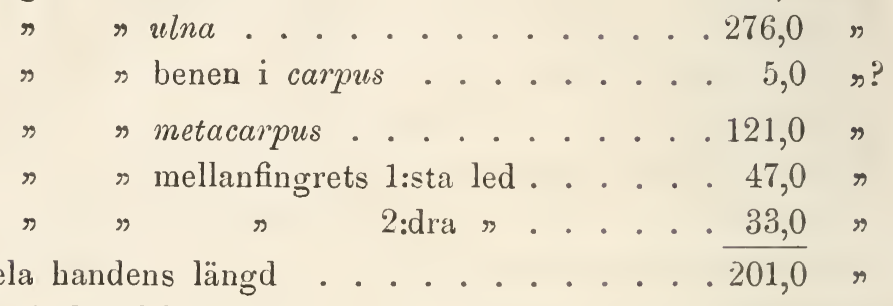

Afståndet från 1:sta bröstkotan till os coccygis 273,0 n

Längden af clavicula . . . . . . 94,0 "

Minsta bredden af clavicula . . . . . 16,0"

Tjockleken $\quad$ \% . . . . . 10,0

Vinkeln emellan bågarna af furcula . . . 1630?

Största afståndet mellan bågarna af furcula . . 100,0 m.m.

Längden af sternum ........ . . 145,0 "

Minsta bredden af sternum ..... . . 75,0

Längden af crista sterni ...... . . . . . . . .

Största höjden af crista sterni . . . . 29,0 "

IIöjden af crista sterni framtill . . . . . 29,0 »?

Längden af foramen sterni . . . . . . . 0,0

Största bredden af foramen sterni . . . . 0,0

29) Hypotriorchis subbuteo L. - (o')

Längden af os humeri . . . . . . 52,0 m.m.

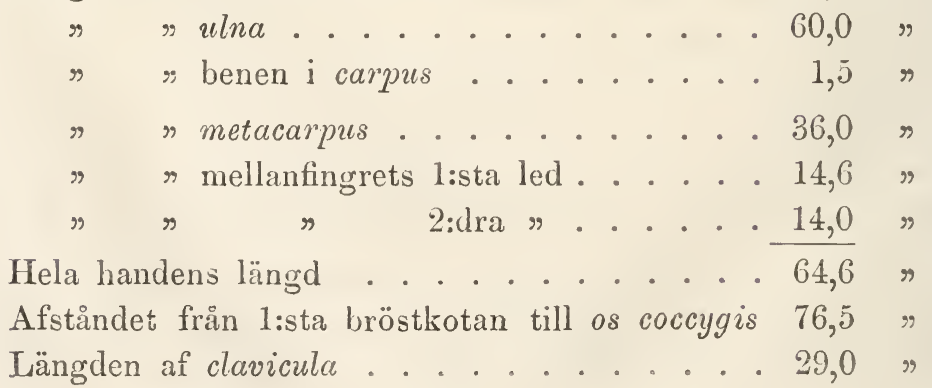


Minsta bredden af clavicula .

3,5 m.m.

Tjockleken

ᄁ

3,0 \%

Vinkeln emellan bågarna af furcula

$75^{\circ}$ ?

Största afståndet mellan bågarna af furcula . . 14,0 m.m.

Längden af sternum (baktill afbruten) . . . 40,0 „?

Minsta bredden af sternum . . . . . 21,0 "

Längden af crista sterni ..... . . . 35,0

Största höjden af crista sterni. . . . . 14,5 "

Höjden af crista sterni framtill ..... . 14,0 "

Längden af foramen sterni ...... ?

Största bredden af foramen sterni . . . . ?

30) Falco peregrinus? Lath. - (Q, Sitka - d.d. Holmberg.)

I ängden af os humeri . . . . . 102,0 m.m.

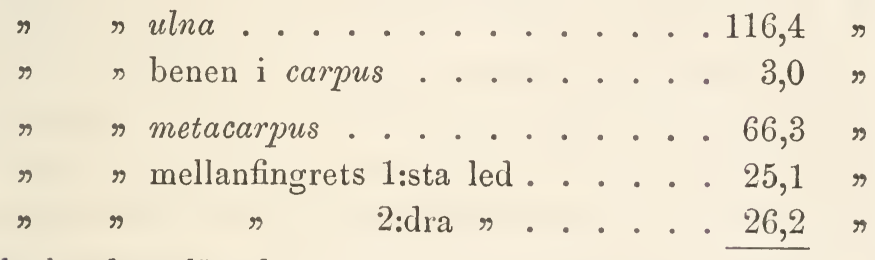

Hela handens längd ........ . . . . . .

Afståndet från 1:sta bröstkotan till os coccygis 157,0 "

Längden af clavicula ....... . 61,0

Minsta bredden af clavicula ..... 7, 7,0

Tjockleken $" \quad$. ...... 5,5

Vinkeln emellan bågarna af furcula . . . $130^{\circ}$ ?

Största afståndet mellan bågarna af furcula . . 27,0 m.m.

Längden af sternum . . . . . . 80,0 "

Minsta bredden af sternum ...... 42,0

Längden af crista sterni ...... . . 66,0 "

Största höjden af crista sterni . . . . . 25,0"

Höjden af crista sterni framtill .... . . 23,0 "

Längden af foramen sterni ..... 12,0 ". . . .

Största bredden af foramen sterni . . . . . 9,0 "

31) Astur (Nisus) nisus L. - (q, Uskela.)

Längden af os humeri . . . . . 60,0 m.m.

$" \quad$ ulna............. $72,0 "$ 
Längden af benen i carpus . . . . 2,4 m.m.?

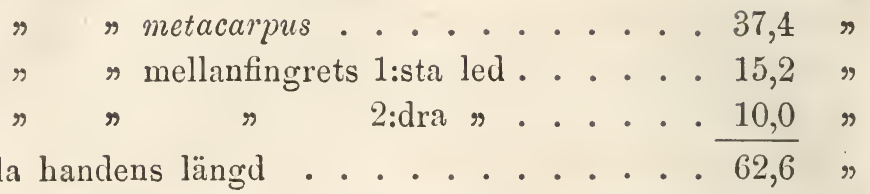

Afståndet från 1:sta bröstkotan till os coccygis 90,0 " Längden af clavicula .......... 35,0 n

Minsta bredden af clavicula...... 3,5 Tjockleken $\quad$ " .......... 3,2 "

Vinkeln emellan bågarna af furcula (inböjd i midten) ?

Största afståndet mellan bågarna af furcula . 17,0 m.m. Längden af sternum . . . . . . 4 49,0

Minsta bredden af sternum ...... 21,0 »

Längden af crista sterni ..... . . 49,0 "

Största höjden af crista sterni . . . . 15,5 »

Höjden af crista sterni framtill . . . . . 12,0 "

Längden af foramen sterni ...... 8,5

Största bredden af foramen sterni .... 5, .

32) Astur palumbarius L. - (

Längden af os humeri ...... 104,5 m.m.

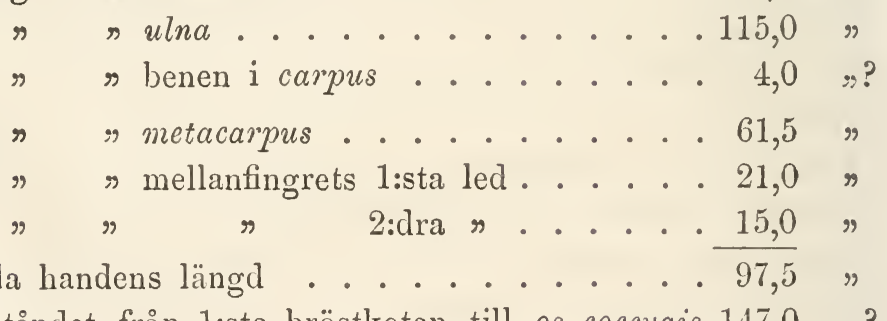

Afståndet från 1:sta bröstkotan till os coccygis 147,0 »?

Längden af clavicula . . . . . . 55,0 "

Minsta bredden af clavicula . . . . . 6,0

Tjockleken $\quad$ " $\quad \ldots . \ldots . .5,5$.

Vinkeln emellan bågarna af furcula . . . 1050 ?

Största afståndet mellan bågarna af furcula . . 34,0 m.m.

Längden af sternum . . . . . . . . 84,0 ”

Minsta bredden af sternum . . . . . . 38,0 "

Längden af crista sterni ...... . . . 71,0 
Största höjlen af crista sterni .

22,0 m.m.

Höjden af crista sterni framtill . . . . 19,0 "

Längden af foramen sterni ...... 13,5 »

Största bredden af foramen sterni . . . . 9, 9,

33) Archibuteo lagopus Brünn. - (o', Germania - pr Brandt.)

Längden af os humeri . . . . . . 147,0 m.m.

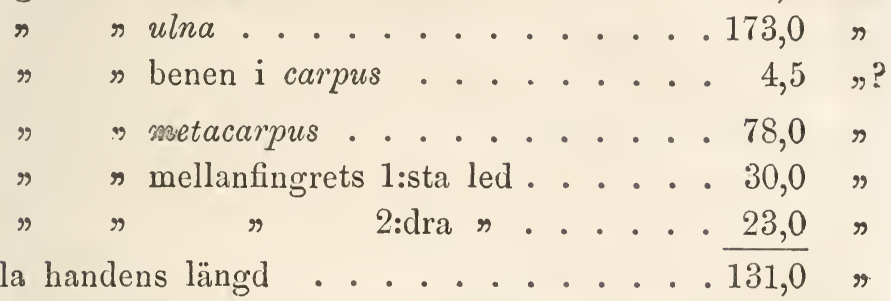

Hela handens längd . . . . . . . 131,0 "

Afståndet från 1:sta bröstkotan till os coccygis 173,0 n Längden af clavicula ....... . . 58,0 "

Minsta bredden af clavicula ...... 8,5

Tjockleken $\quad " \quad \ldots \ldots \ldots, 6,0$.

Vinkeln emellan bågarna af furcula . . . $150^{\circ}$ ?

Största afståndet mellan bågarna af furcula . . 36,0 m.m.

Längden af sternum . . . . . . 8 86,0 ”

Minsta bredden af sternum . . . . . 46,0 "

Längden af crista sterni ...... . . 72,0 ”

Största höjden af crista sterni . . . . 20,0 "

Höjden af crista sterni framtill . . . . 20,0 \#

Längden af foramen sterni* ${ }^{*}$. . . . . 4, 4,5 "

Största bredden af foramen sterni ..... 3,5 "

34) Buteo vulgaris Bechst. (Falco buteo L.) -

(ㅇ, Svartå - d.d. Linder.)

Längden af os humeri . . . . . . 95,0 m.m.

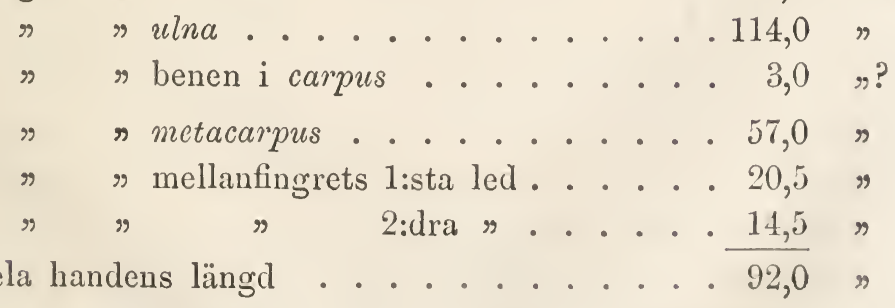

*) Finnes endast på högra sidan. 
Afståndet från 1:sta bröstkotan till os coccygis 128,0 m.m. Längden af clavicula . . . . . . . 39,5 " Minsta bredden af clavicula ...... . . 5,5 "

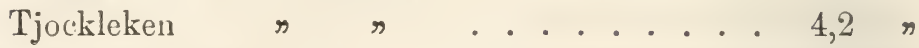
Vinkeln emellan bågarna af furcula . . . . 1250?

Största afståndet mellan bågarna af furcula . . 27,0 m.m. Längden af sternum . . . . . . . 60,0 Minsta bredden af sternum . . . . . . 32,0 Längden af crista sterni . . . . . . . 52,0 \% Största höjden af crista sterni . . . . . . 15,0 " Höjden af crista sterni framtill . . . . . 14,0 " Längden af foramen sterni . . . . . . 6,7 " . . . Största bredden af foramen sterni ... . . 4, 4,0 "

35) Pernis apirorus L. - (ㅇ, d.d. Brenner - ppt. Hacklin.) Längden af os humeri . . . . . . . 106,0 m.m.

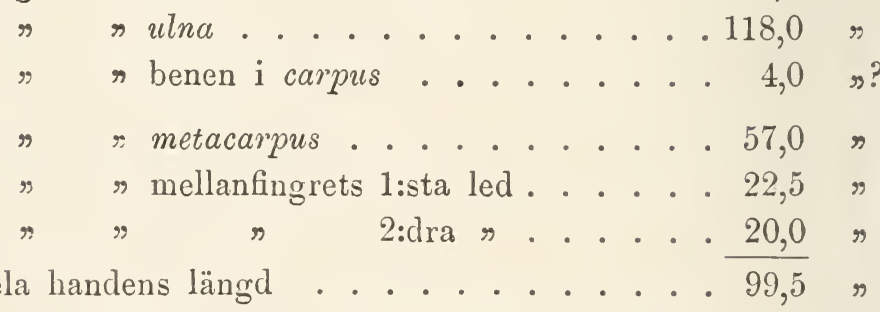
Afståndet från 1:sta bröstkotan till os coccygis 139,0 \% Längden af clavicula . . . . . . . 4 46,0 \% Minsta bredden af clavicula ...... . 8,0 \% Tjockleken $"$ "....... . . 5, . 5,0 Vinkeln emellan bågarna af furcula . . . . $115^{\circ}$ ? Största afståndet mellan bågarna af furcula . . 30,0 m.m. Längden af sternum . . . . . . . 63,0 Minsta bredden af sternum . . . . . . 35,0 Lïngden af crista sterni . . . . . . . 55,0 " . . Största höjden af crista sterni . . . . . . 19,5 „? Höjden af crista sterni framtill . . . . . 19,5 "? Längden af foramen sterni . . . . . . 0,0 0,0 Största bredden af foramen sterni . . . . 0,0, 0 
36) Circus (Strigiceps) cyaneus L. - (Germania - d. Brandt.)

Längden af os humeri . . . . . . . 81,0 m.m.

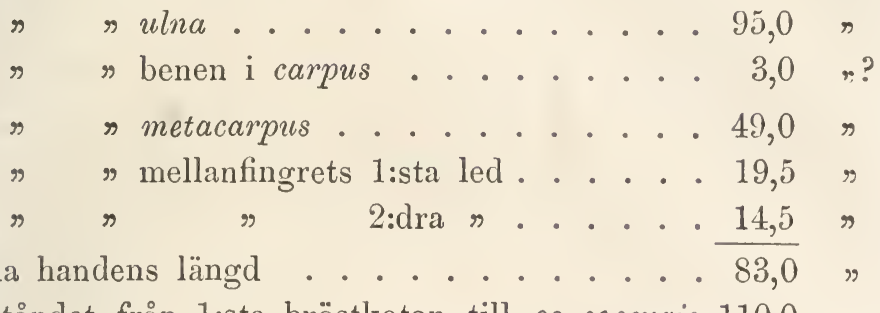

Afståndet från 1:sta bröstkotan till os coccygis 110,0 \% Längden af clavicula . . . . . . . 37,0 " Minsta bredden af clavicula . . . . . . 4, 4,6

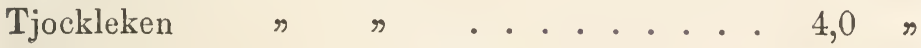
Vinkeln emellan bågarna af furcula . . . . $130^{\circ}$ ? Största afståndet mellan bågarna af furcula . . 23,6 m.m. Längden af sternum . . . . . . . 4 49,0 》 Minsta bredden af sternum ..... . 26,0 " Längden af crista sterni . . . . . . . 46,0 " Största höjden af crista sterni . . . . . . 14,0 " Höjden af crista sterni framtill . . . . . 13,0 " Längden af foramen sterni . . . . . . . 4,5 " Största bredden af foramen sterni . . . . 3,0

37) Sarcoramphus gryphus L. - $\sigma^{*}$.)

Längden af os humeri . . . . . . . 270,0 m.m.

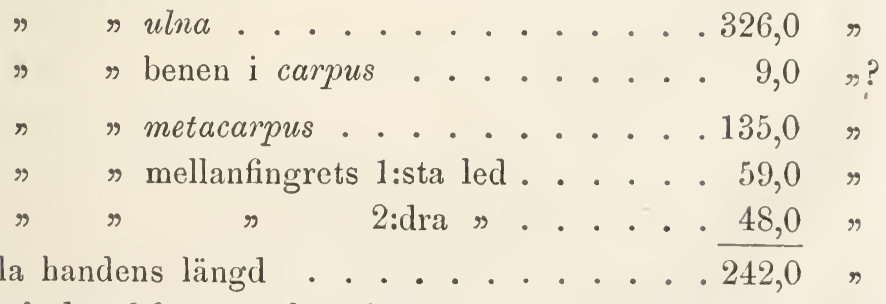

Afståndet från 1:sta bröstkotan till os coccygis 290,0 . Iängden af clavicula . . . . . . . 108,0 \% Minsta bredden af clavicula . . . . . 16,6 \% Tjockleken $\quad$ " . . . . . . 12,0 Vinkeln emellan bågarna af furcula . . . 1280? Största afståndet mellan bågarna af furcula . . 65,0 m.m. Längden af sternum ........ . . 155,0 n 
Minsta bredden af sternum 75,0 m.m.

Längden af crista sterni . . . . . . 155,0 "

Största höjden af crista sterni . . . . . 39,0

Höjden af crista sterni framtill . . . . . . 30,0 »

Längden af foramen sterni . . . . . . 0,0

Största bredden af foramen sterni ..... 0,0,0

38) Vultur (Gyps) fulrus Gmel. - (Aegyptus, ppt. Helenius 1859.)

Längden of humeri . . . . . 260,0 m.m.

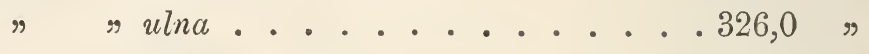

" benen i carpus ....... 6, 6, .

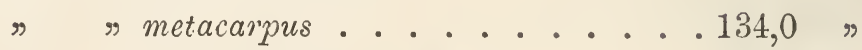

" mellanfingrets $1:$ sta led .... . 54,0

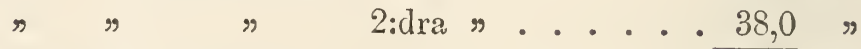

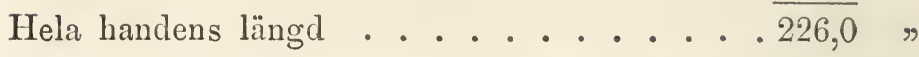

Afståndet från 1:sta bröstkotan till os coccygis 280,0 \#

Längden af clavicula ....... 105,0 "

Minsta bredden af clavicula ...... 12,0

Tjockleken $\quad " \quad \ldots . . . .10,6$.

Vinkeln emellan bågarna af furcula . . . 1150?

Största afståndet mellan bågarna af furcula . . 76,0 m.m.

Längden af sternum .......... 158,0 "

Minsta bredden af sternum ...... 81,0 "

Längden af crista sterni . . . . . . . 122,0 "

Största höjden af crista sterni. . . . 19,0 "

Höjden af crista sterni framtill ..... . 14,0 "

Längden af foramen sterni ...... 25,0 "

Största bredden af foramen sterni . . . 15,0

39) Nyctea nirea Thunb. (Strix nyctea L.) -

(Lskiela - d.d. E. W. Sallmén.)

Längden af os humeri . . . . . 158,0 m.m.

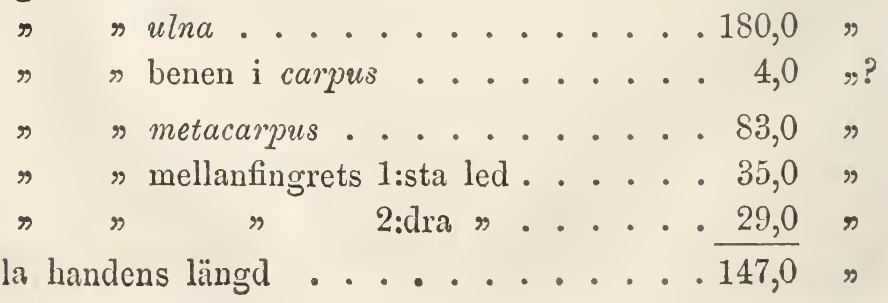


Afståndet från 1:sta bröstkotan till os coccygis $163,0 \mathrm{~m} . \mathrm{m}$. Längden af clavicula ....... 67,0 "... Minsta bredden af clavicula...... 9,0 Tjockleken

Vinkeln emellan bågarna af furcula $7,0 \quad \%$

Största afståndet mellan bågarna af furcula . . 36,0 n

Längden af sternum . . . . . . . 76,0 ”

Minsta bredden af sternum ..... 47,0

Längden af crista sterni ...... . . 66,0 ”

Största höjden af crista sterni . . . . . 23,0 "

Höjden af crista sterni framtill . . . . . 22,0 ?

Längden af incisura sterni exterior . . . . 25,0

Största bredden af incisura sterni exterior . . 9,0 ”

Längden af incisura sterni interior . . . . 10,0 "

Största bredden af incisura sterni interior . . 6,0 "

40) Nyctea nirea Thunb. (Strix nyctea L.) -

(우 - ppt. Silfverberg 1866.)

Längden af os humeri . . . . . 157,0 m.m.

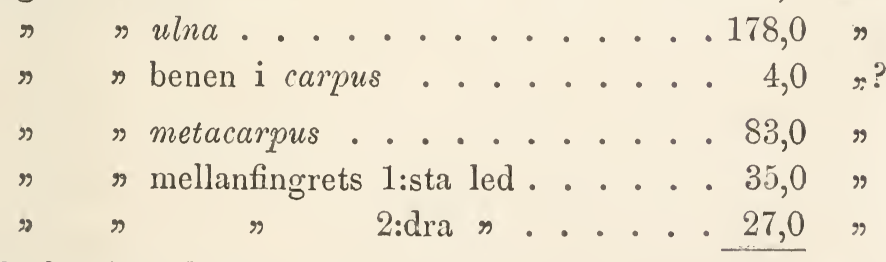

Hela handens längd . . . . . . . 145,0

Afståndet från 1:sta bröstkotan till os coccygis 178,0 \#

Längden af clavicula . . . . . . 6 65,0"

Minsta bredden af clavicula ...... 9 9,0 "

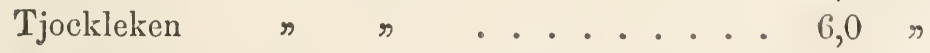

Vinkeln emellan bågarna af furcula . . . 8 850?

Största afståndet mellan bågarna af furcula . . 48,0 m.m.

Längden af sternum . . . . . . . 78,0

Minsta bredden af sternum ...... 48,0

Längden af crista sterni ...... . . 70,0 »

Största höjden af crista sterni . . . . 25,0 "

Höjden af crista sterni framtill .... . 24,0 "

Lüngden af incisura sterni exterior ...226,0 
Största bredden af incisura stemi exterior . . 9,0 m.m. Längden af incisura sterni interior . . . . . 4,0 " Största bredden af incisura sterni interior . . 2,0 \%

41) Bubo maximus Ranz. (Strix bubo L.) - (Uskela.)

Längden af os humeri . . . . . . 160,0 m.m.

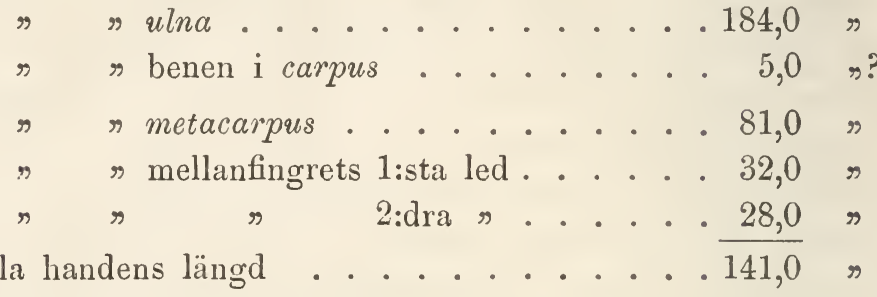

Hela handens längd . . . . . . . . . 141,0
Afståndet från 1:sta bröstkotan till os coccygis 173,0 \%

Längden af clavicula . . . . . . . 68,0 "

Minsta bredden af clavicula ...... . 9,0 9

Tjockleken $\quad$ \% . . . . . 6, 6, 6

Vinkeln emellan bågarna af furcula . . . . $80^{\circ}$ ?

Största afståndet mellan bågarna af furcula . . 47,0 m.m.

Längden af sternum ....... . . 76,0 \%

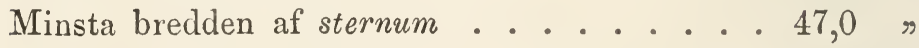

Längden af crista sterni . . . . . . 68,0 "

Största höjden af crista sterni. . . . . 25,0

Höjden af crista sterni framtill . . . . . 25,0 "

Längden af incisura sterni exterior . . . . 20,0 \%

Största bredden af incisura sterni exterior . . 7,0

Längden af' incisura sterni interior . . . . 6,0 "

Största höjden af incisura sterni interior . . 5, 5,

42) Bubo maximus Ranz. (Strix bubo L.) -

(Exemplaret i zool. museum.)

Längden af os humeri . . . . . . 169,0 m.m.

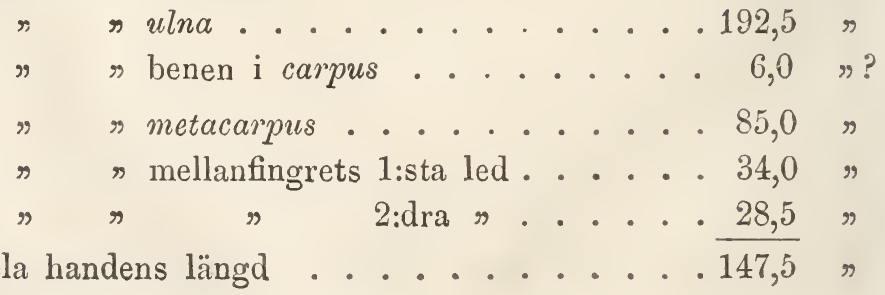


Afståndet från 1:sta bröstkotan till os coccygis 190,0 m.m. Längden af clavicula.

70,0 "
11,0 "
6,4 "
750 ?

$75^{\circ}$ ?

Vinkeln emellan bågarna af furcula

45,0 m.m.

Minsta bredden af sternum . . . . . . 47,5

Längden af crista sterni . . . . . . 75,0 \%

Största höjden af crista sterni. . . . . . 29,5

Höjden af crista sterni framtill . . . . . . 28,6

Längden af incisura sterni exterior . . . . 22,6 "

Största bredden af incisura sterni exterior . . 9,4

Längden af incisura sterni interior . . . . 11,5 "

Största bredden af incisura sterni interior . . . 7,5

43) Athene passerina L. - (D.d. E. Rotkirch - ppt. Hacklin.)

Längden af os humeri . . . . . . 34,0 m.m.

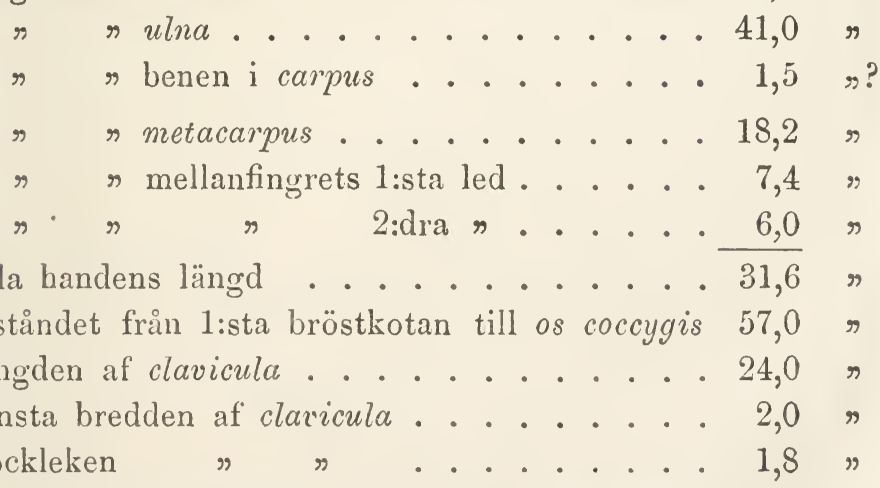

Vinkeln emellan bågarna af furcula (icke ossifierad) ?

Största afståndet mellan bågarna af furcula . . 8,0 m.m.

Längden af sternum . . . . . . . . 25,0 "

Minsta bredden af sternum ....... 14,0

Längden af crista sterni . . . . . . 18,0 \#

Största höjden af crista sterni...... . 6,0 6,0

Höjden af crista sterni framtiil . . . . . . ?

Längden af incisura sterni exterior . . . . 11,0 "

(F. W. M-n V. 1867.) 
Största bredden af incisura sterni exterior 3,0 m.m.

Längden af incisura sterni interior 7,0 \% Största bredden af incisura sterni interior 3,0 r

44) Syrnium uralense Pall. (Strix liturata auct. svec.) - (Uskela.) Längden af os humeri . . . . . . . 105,0 m.m. Längden af $u \ln a$. . . . . . . . . . . . . . . . . . . .

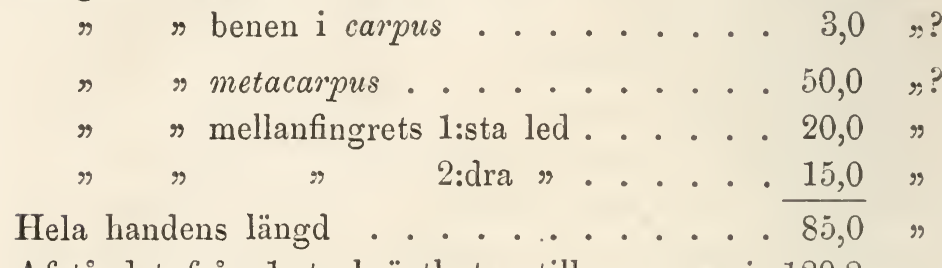

Afståndet från 1:sta bröstkotan till os coccygis 129,2 "

Längden af clavicula . . . . . . . 4 45,0 " . .

Minsta bredden af clavicula . . . . . . 5, 5,6

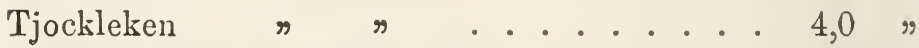

Vinkeln emellan bågarna af furcula . . . . $70^{\circ}$ ?

Största afståndet mellan bågarna af furcula . . 35,0 m.m. Längden af sternum . . . . . . . . 51,0 "

Minsta bredden af sternum . . . . . . 29,0 " . . . .

Längden af crista sterni . . . . . . . 45,0 " . . . . .

Största höjden af crista sterni . . . . . 14,0 " . . .

Höjden af crista sterni framtill . . . . . 14,0 "

Längden af incisura sterni exterior . . . . 21,0 "

Största bredden af incisura sterni exterior . . 9,0 "

Längden af incisura sterni interior . . . . 9,0 "

Största höjden af incisura sterni interior . . . 5,5

45) Columba livia Briss. v. domestica.

Längden af os humeri

$47,0 \mathrm{~m} \cdot \mathrm{m}$.

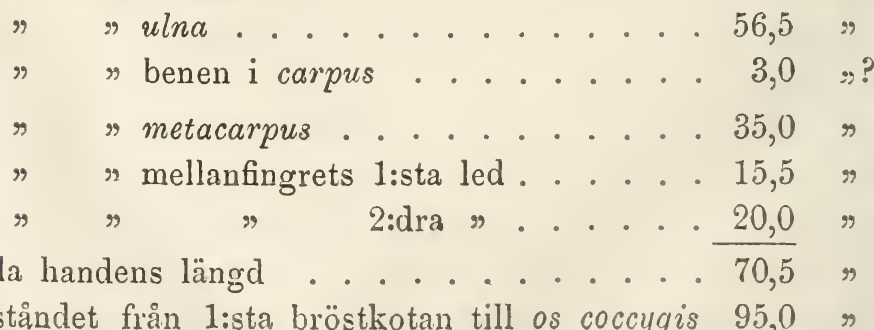

Afståndet från 1:sta bröstkotan till os coccygis 95,0 \% 
Längden af clavicula 39,0 m.m.

Minsta bredden af clavicula 4,0 ; Tjockleken " $3,0 \%$

Vinkeln emellan bågarna, af furcula $50^{\circ}$ ?

Största afståndet mellan bågarna af furcula 17,5 m.m. Längden af sternum 64,0 \% Minsta brelden af sternum . . . . . . 24,0 "

Längden af crista sterni (missbildad) . . . 66,0 " Största höjden af crista sterni... . . . 23,0 " Höjden af crista sterni framtill . . . . . 20,0 》 Längden af incisura sterni (exterior) . . . . 23,5 " Största bredden af incisura sterni (exterior) 10,0 \% Längden af foramen sterni (interior) . . . . 10,0" Största bredden af foramen sterni (interior) . . 6,0"

46) Columba oenas L. - ( $\sigma$, Germania - pr. Brandt.) Längden af os humeri 43,0 m.m.

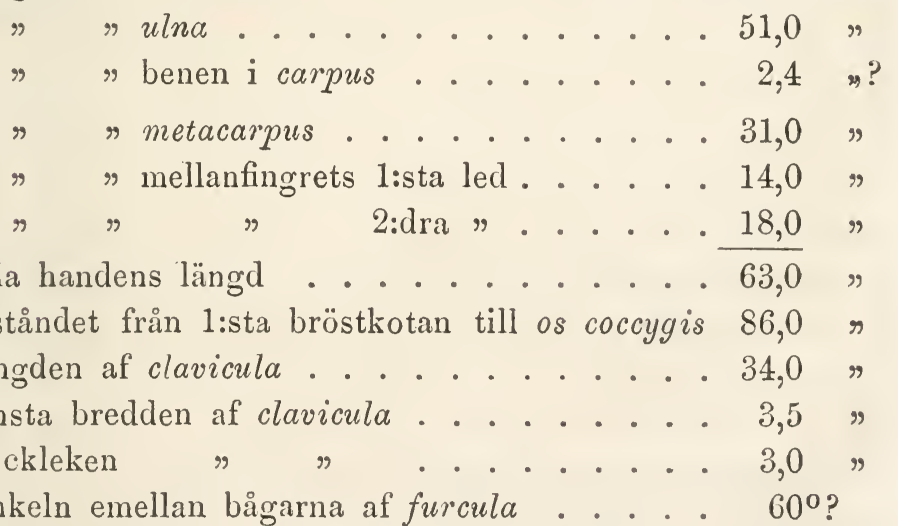

Hela handens längd ....... . . . 63,0 " Afståndet från 1:sta bröstkotan till os coccygis 86,0 \% Längden af clavicula . . . . . . . . 34,0 " Minsta bredden af clavicula ...... . . . . . . . . . Tjockleken " " Vinkeln emellan bågarna af furcula . . . . $60^{\circ}$ ? Största afståndet mellan bågarna af furcula . . 22,0 m.m. Längden af sternum . . . . . . . . . 57,0 " . . . . Minsta bredden af sternum . . . . . 21,0 Längden af crista sterni . . . . . . 59,0 Största höjden af crista sterni . . . . . 23,0 " Höjden af crista sterni framtill . . . . . 21,0 " . . Längden af incisura sterni (cxterior) . . . 22,0 " Största bredden af incisura sterni (exterior) - 10,0" 
Jängden af foramen sterni (interior). 13,0 m.m. Största höjden af foramen sterni (interior) . . 6,0

47) Paro cristatus L., domesticus. - (D.d. Etholén.)

Längden af os humeri . . . . . . . 115,0 m.n.

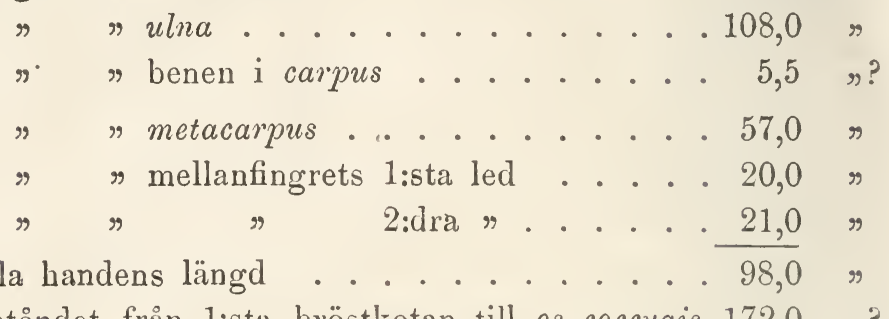

Afståndet från 1:sta bröstkotan till os coccygis 172,0 "? Längden af clavicula . . . . . . . . . 72,0 " Minsta bredden af clavicula . . . . . . 7,5 " Tjockleken $" \quad$. . . . . 6, 6, .

Vinkeln emellan bågarna af furcula . . . $65^{\circ}$ ?

Största afståndet mellan bågarna af furcula . . 32,0 m.m. Längden af sternum . . . . . . . 119,0 \% Minsta bredden af sternum . . . . . . 34,0 \% Längden af crista sterni . . . . . . . 104,0 " . . . . . Största höjden af crista sterni. . . . . . 48,0 " Höjden af crista sterni framtill . . . . . 45,0 Längden af incisura sterni exterior . . . . 33,0 Största bredden af incisura sterni exterior . . 18,0 \% Längden af incisura sterni interior . . . . . 74,0 \% Största bredden af incisura sterni interior . . 23,0

48) Numida meleagris L. - (‥ - D.d. L. Hirn.)

Längden af os humeri 78,0 m.m.

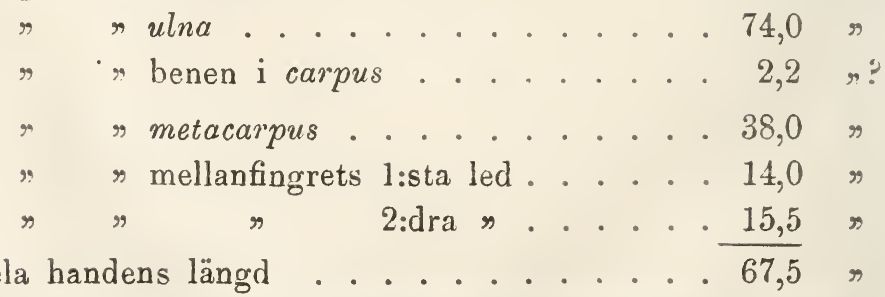

Afståndet från 1:sta bröstkotan till os coccygis 166,0 " 
Längden af clavicula

Minsta bredden af clavicula

$52,0 *) \mathrm{m} \cdot \mathrm{m}$.

Tjockleken

भ

$6,2 \quad 9$

Vinkeln emellan bågarna af furcula

5,0 "

$75^{\circ}$ ?

Största afståndet mellan bågarna af furcula . . 27,0 m.m.

Längdeu af sternum

$88,0 \%$ ?

Minsta bredden af sternum

27,0 \%

Längden af crista sterni (missbildad) . . . . 77,0

Största höjden af crista sterni . . . . . . 33,0 \%

Höjden af crista sterni framtill . . . . . 29,0 "

Längden af incisura sterni exterior . . . . 28,0 "

Största bredden af incisura sterni exterior . . 11,0 "

Längden af incisura sterni interior . . . . 53,0 "

Största bredden af incisura sterni interior . . 11,5 "

49) Gallus domesticus Briss. - (오)

Längden af os humeri

79,0 m.m.

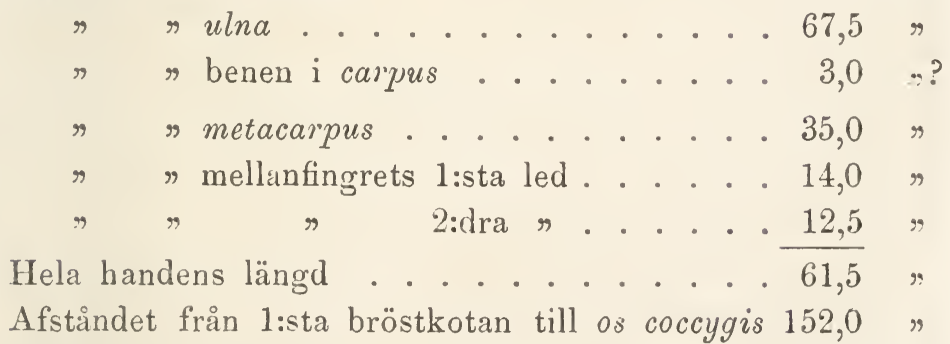

Längden af clavicula . . . . . . . 53,0 "

Minsta bredden af clavicula..... . . . 5,2 5

Tjockleken " $"$. . . . . . . 5, .

Vinkeln emellan bågarna af furcula . . . . $55^{\circ}$ ?

Största afståndet mellan bågarna af furcula . 24,0 m.m.

Längden af sternum . . . . . . . . . 98,0 "

Minsta bredden af sternum . . . . . . 30,0 "

Längden af crista sterni . . . . . . . 86,0 "

Största höjden af crista sterni . . . . . . 26,0 ,

Höjden af crista sterni framtill . . . . . . 24,5 "

Längden af incisura sterni exterior . . . . . 38,0 "

*) $\mathrm{P} \stackrel{a}{\mathrm{a}}$ högra sidan $55,0 \mathrm{~m} . \mathrm{m}$. 
Största bredden af incisura sterni exterior . . 13,0 m.m. Längden af incisura sterni interior . . . . 65,0 " Största bredden af incisura sterni interior . . 18,0 "

50) Gennaeus nycthemerus L. - ( $\sigma^{\top}-$ ppt. Hacklin.)

Längden af os humeri . . . . . . . 78,0 m.m.

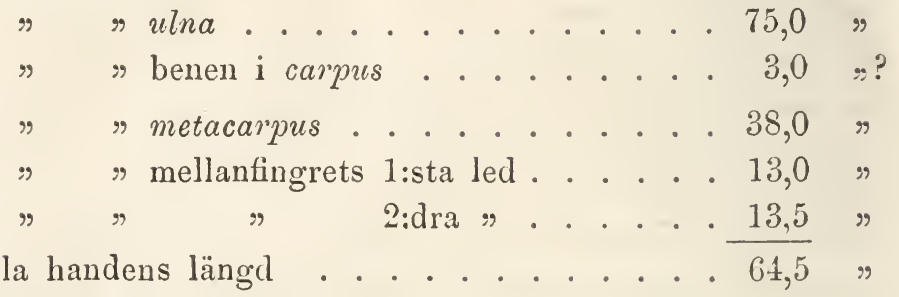

Afståndet från 1:sta bröstkotan till slutet af $3:$ dje

svanskotan . . . . . . . 180,0 "

De felande vertebrae coccygeae beräknade till . 10,0 $\%$ ? Längden af clavicula . . . . . . . 56,j " . . . . .

Minsta bredden af clavicula . . . . . . 5,5

Tjockleken " $"$. . . . . . 5, 5

Vinkeln emellan bågarna af furcula . . . . $70^{\circ}$ ?

Största afståndet mellan bågarna af furcula . . 37,0 m.m.

Längden af sternum . . . . . . . 120,0 " . . . . . . . .

Minsta bredden af sternum . . . . . . 35,0 \%

Längden af crista sterni . . . . . . 106,0 »?

Största höjden af crista sterni . . . . . . 33,0 "

Höjden af crista sterni framtill . . . . . 32,0 ${ }^{*}$ )

51) Tetrao urogallus L. - (Uskela.)

Längden af os humeri . . . . . . . 125,0 m.m.

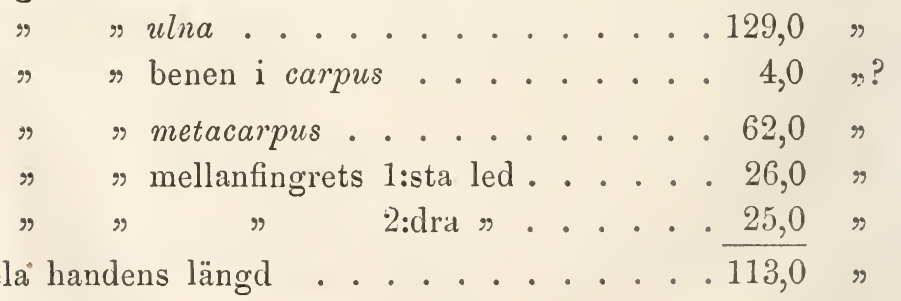

*) Emedan skelettet är ofullständigt, kunna nảgra mâttsbestämningar öfver inskärningarna på bröstbenet ieke uppges. 
Afstảndet från 1:sta bröstkotan till os coccygis 234,0 m.m. Längden af clavicula . . . . . . . . 91,0 "

Minsta bredden af clavicula . . . . . 9, 9,5 Tjockleken " $"$...... 8,0 \%

Vinkeln emellan bågarna af furcula . . . . $60^{\circ}$ ?

Största afståndet mellan bågarna af furcula . . 42,0 m.m. Längden af sternum . . . . . . . . 164,0 "

Minsta bredden af sternum . . . . . . 53,0 "

Längden af crista sterni . . . . . . . 142,0 \#?

Största höjden af crista sterni . . . . . 53,0 "

Höjden af crista sterni framtill . . . . . 53,0 "

Längden af incisura sterni exterior . . . . 66,0"

Största bredden af incisura sterni exterior . . 29,0"

Längden af incisura sterni interior . . . 108,0 n

Största bredden af incisura sterni interior . . 26,0

52) Tetrao hybridus L. - (D.d. Ekebom.)

Jängden af os humeri . . . . . . . . 103,8 m.m.

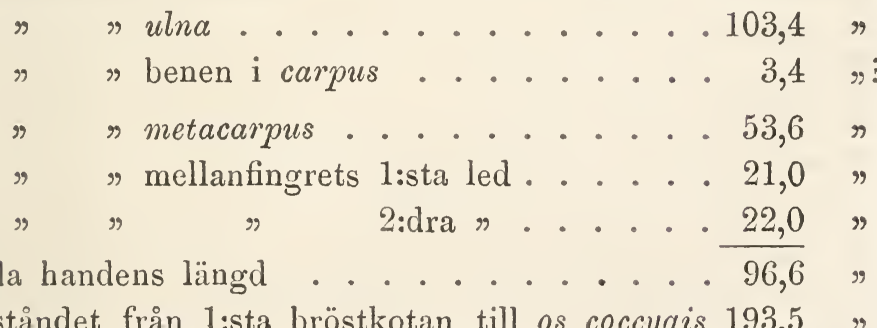

Afståndet från 1:sta bröstkotan till os coccygis 193,5 "

Längden af clavicula . . . . . . . 77,0 "

Minsta bredden af clavicula...... . . 8,0 "

Tjockleken " ". . . . . . 6, 6,0 " .

Vinkeln emellan bågarna af furcula . . . 5 550?

Största afståndet mellan bågarna af furcula . . 33,5 m.m.

Längden af sternum . . . . . . . . 142, . . ?

Minsta bredden af sternum . . . . . . 43,0 "

Längden af crista sterni . . . . . . . 124,0 " . . . . .

Största höjden af crista sterni . . . . . . 46,0 "

Höjden af crista sterni framtill . . . . . . 46,0 "

Längden af incisura sterni exterior . . . . 67,5 " 
Största bredden af incisura sterni exterior . . 18,5 m.m. Längden af incisura sterni interior . . . . 102,5 \% Största bredden af incisura sterni interior . . 19,0 \%

53) Tetrao tetrix L. - (Uskela.)

Längden af os humeri . . . . . . . 83,0 m.m.

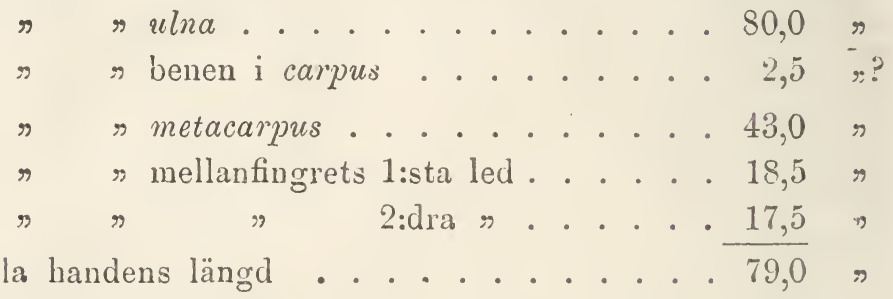

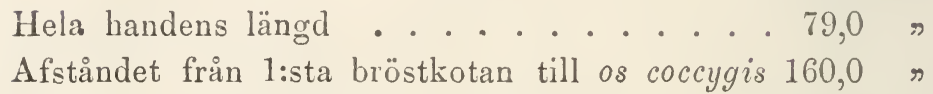
Längden af clavicula . . . . . . . 63,0 " Minsta bredden af clavicula...... . 6, 6,5 " Tjockleken $"$ ". . . . . . . 5, . 5,0

Vinkeln emellan bågarna af furcula . . . . $50^{\circ}$ ?

Största afståndet mellan bågarna af furcula . - 28,0 " Längden af sternum . . . . . . . 120,0 " Minsta bredden af sternum . . . . . . 35,5 \% Längden af crista sterni . . . . . . . 106,0 Största höjden af crista sterni. . . . . . 38,0 \# Höjden af crista sterni framtill . . . . . 36,0 Längden af incisura sterni exterior . . . . 5 5,0 " Största bredden af incisura sterni exterior . . 20,0 Längden af incisura sterni interior . . . . 77,0 " Största bredden af incisura sterni interior . . 16,0 "

54) Bonasa bonasia I. -- (Uskela.:

Längden af os humeri . . . . . . 47,0 m.m.

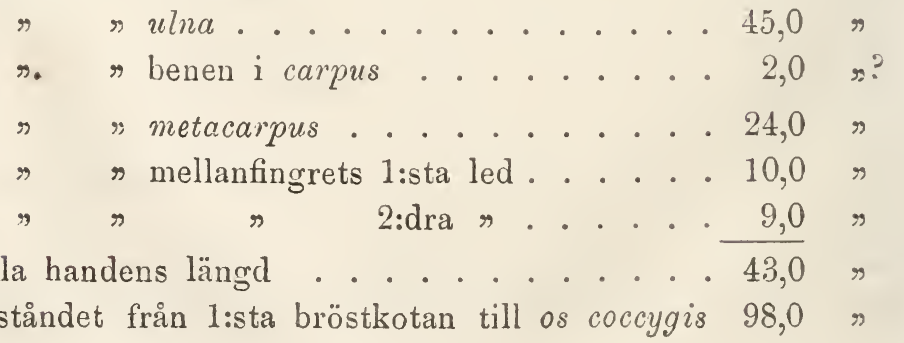


Längden af clavicula

37,0 m.m.

Minsta bredden af clavicula. 3,6 \%

Tjockleken

"

3,5 \%

Vinkeln emellan bågarna af furcula . . . . $50^{\circ}$ ?

Största afståndet mellan bågarna af furcula . . 13,0 m.m.

Längden af sternum

$75,0 \quad \%$

Minsta bredden af sternum

$22,0 \%$

Längden af crista sterni

$61,0 \%$

Största höjden af crista sterni . . . . . . 22,0 "

Höjden af crista sterni framtill . . . . . . 22,0

Längden af incisura sterni exterior . . . . 35,0 "

Största bredden af incisura sterni exterior . . ?

Längden af incisura sterni interior . . . . . 50,0 "

Största bredden af incisura sterni interior . . 14,0 "

55) Lagopus alba Gmel. - ( $\sigma^{7}$, Kuopio.)

Längden af os humeri . . . . . . . 62,0 m.m.

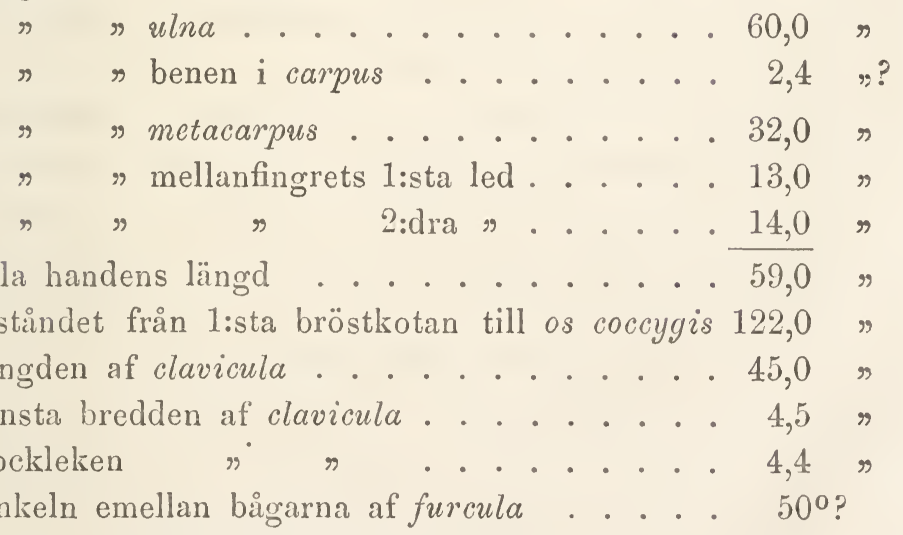

Största afståndet mellan bågarna af furcula . . 22,0 m.m.

Längden af sternum . . . . . . . . . 88,0 "?

Minsta bredden af sternum . . . . . . 32, $0^{\circ}$ "

Längden af crista sterni . . . . . . . 68,0

Största höjden af crista sterni. . . . . . 28,0 " .

Höjden af crista sterni framtill . . . . . 28,0 "

Längden af incisura sterni exterior . . . . 37,0

Största bredden af incisura sterni exterior . . ? 
Längden af incisura sterni interior . . . . 61,0 m.m. Största höjden af incisura sterni interior . . . 13,0 "

56) Ardea cinerea L. - (Aegyptus - d.d. Wallin.)

Längden af os humeri . . . . . . . 179,0 m.m.

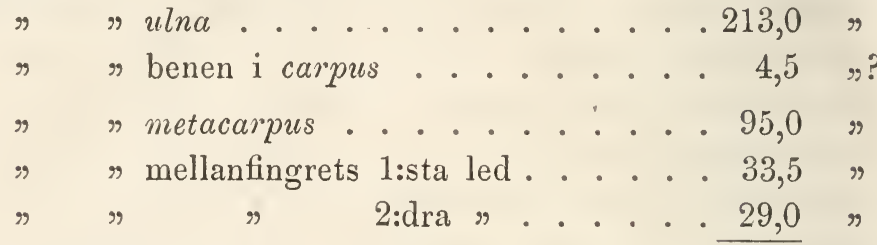

Hela handens längd . . . . . . . . $\overline{157,5}$ \%

Afståndet från 1:sta bröstkotan till os coccygis 205,0 "

Längden af clavicula . . . . . . . 69,0 " . . . ( . .

Minsta bredden af clavicula ..... . 6, 6,0

Tjockleken $" \quad$ ". . . . . . . 5,5

Vinkeln emellan bågarna af furcula . . . . $70^{\circ}$ ?

Största afståndet mellan bågarna af furcula . . 32,6 m.m.

Längden af sternum . . . . . . . 85,0 " . . .

Minsta bredden af sternum . . . . . . 36,5 " . . . .

Längden af crista sterni . . . . . . . 78,0 ". . . .

Största höjden af crista sterni . . . . . . 26,0 " . .

Höjden af crista sterni framtill . . . . . 20,5 "

Längden af incisura sterni . . . . . . 13,5 "

Största bredden af incisura sterni . . . . 10,5 »

57) Ciconia alba Briss. (Ardea ciconia L.) -

( $\sigma^{\top}$, Germania - ppt. Grönwall.)

Längden af os humeri . . . . . . . 198,0 m.m.

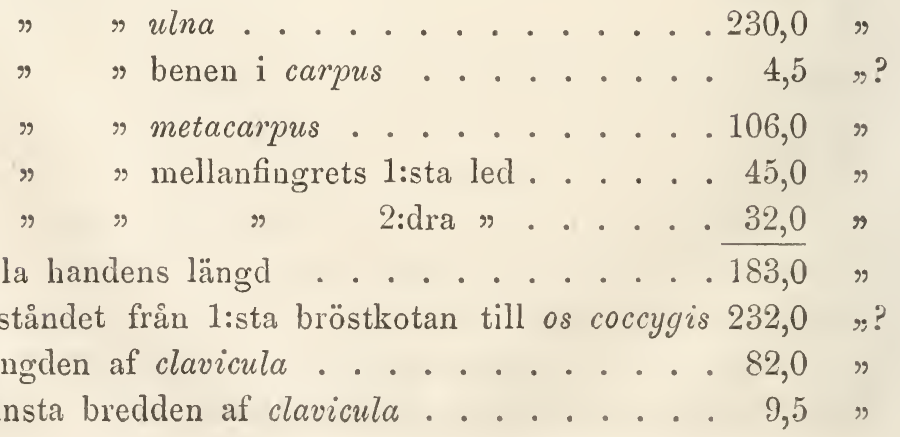

Hela handens längd

Afståndet från 1:sta bröstkotan till os coccygis 232,0 „?

Längden af clavicula . . . . . . . 82,0 "

Minsta bredden af clavicula ..... . . 9, . . . " 
Tjockleken af clavicula

Vinkeln emellan bågarna af furcula

8,5 m.m.

Största afståndet mellan bågarna af furcula . . 51,0 m.m.

Längden af sternum . . . . . . . 9 90,0 "

Minsta bredden af sternum . . . . . . 54,0 5

Längden af crista sterni . . . . . . . 84,5 " . . . . . .

Största höjden af crista sterni. . . . . 4 46,0 "

Höjden af crista sterni framtill (framom sternum) 44,0 "

Längden af incisurca sterni . . . . . . . 16,0 n

Största bredden af incisura sterni . . . . . 19,5 "

58) Grus cinerea Bechst. (Ardea grus L.) -

(Tammela - d.d. Wahren.)

Längden af os humeri

. 228,0 m.m.

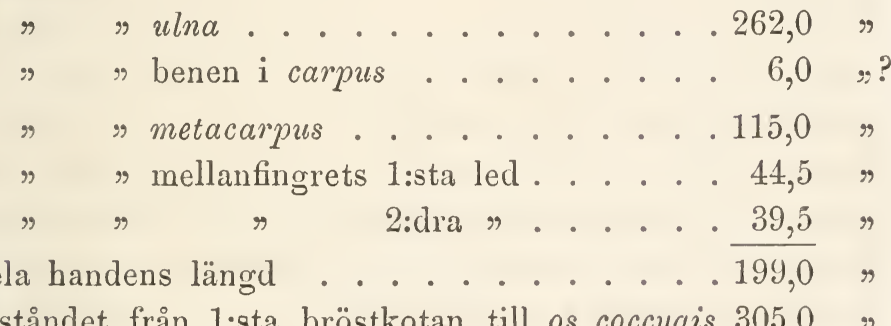

Afståndet från 1:sta bröstkotan till os coccygis 305,0 "

Längden af clavicula . . . . . . . . 92,0 "

Minsta bredden af clavicula . . . . . 15,0 ".

Tjockleken $\quad$ " . . . . . . 11,0 "

Vinkeln emellan bågarna af furcula . . . . $45^{\circ}$ ?

Största afståndet mellan bågarna af furcula . . 45,0 m.m.

Längden af sternum . . . . . . . . 165,0 "

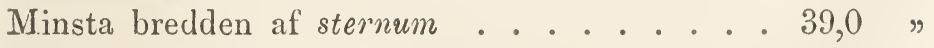

Längden af crista sterni . . . . . . 171,0 "

Största höjden af crista sterni . . . . . . . 59,0 "

Höjden af crista sterni framtill . . . . . . 39,0 " . . .

Längden af incisura sterni . . . . . . . 0,0 " .

Största bredden af incisura sterni . . . . 0,0,

59) Vanellus cristatus Mey. \& IV. (Tringa Vanellus L.) -

(Heinola, d.d. Moilanen - ppt. Fagerström.)

Längden af os humeri . . . . . . 64,0 m.m. 
Längden af ulna

74,5 m.in.

" $\quad$ benen i carpus

3,0 \%?

" metacarpus.

39,5 \%

" mellanfingrets 1:sta led .... . 14,6"

" $" 2$ :dra $\% . . .13,5 \%$

Hela handens längd . . . . . . . . . . $\overline{67,6}$ »

Afståndet från 1:sta bröstkotan till os coccygis 86,0 "

Längden af clavicula . . . . . . . 25,5 »

Minsta bredden af clavicula ....... . . 3,5 \%

Tjockleken $\quad$ "........ . . 3,0 "

Vinkeln emellan bågarna af furcula . . . 1050?

Största afståndet mellan bågarna af furcula . . 15,0 m.m.

Längden af sternum . . . . . . . . 51,0 r

Minsta bredden af sternum . . . . . 20,0

Längden af crista sterni . . . . . . . . 50,0 " . . . . . . . .

Största höjden af crista sterni . . . . . . 18,0 "

Höjden af crista sterni framtill . . . . . 17,5 \%

Längden af incisura sterni exterior . . . . 11,2 "

Största bredden af incisura sterni exterior . . 5,5

Längden af incisura sterni interior . . . . 6,5

Största bredden af incisura sterni interior . . 2,5 "

60) Strepsilas interpres L. - ( $\sigma^{\top}$, Aboae - ppt. Hacklin.)

Längden af os humeri . . . . . . . . 38,5 m.m.

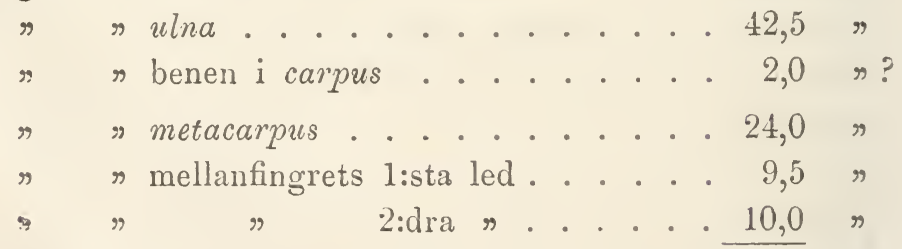

Hela handens längd . . . . . . . . 4 43,5 "

Afståndet från 1:sta bröstkotan till os coccygis 66,0 \%

Längden af clavicula . . . . . . . . 19,4 " . . .

Minsta bredden af clavicula . . . . . . . 2,4

Tjockleken $" \quad$ ". . . . . . . 2, 2,0

Vinkeln emellan bågarna af furcula . . . $75^{\circ}$ ?

Största afståndet mellan bågarna af furcula . 12,4 m.m. 
Längden af sternum . . . . . . . 38,0 m.m.

Minsta bredden af sternum ...... . . 16,5 "

Längden af crista sterni . . . . . . . 37,0 \%

Största höjden af crista sterni. . . . . 15,0

Höjden af crista sterni framtill ... . . . 14,0 "

Längden af incisura sterni exterior . . . . 10,0 "

Största bredden af incisura sterni exterior . . 5,5 "

Längden af incisura sterni interior . . . . 6,5 \%

Största bredden af incisura sterni interior . . 3,0 \%

61) Tudromias morinellus L. - ( $\sigma^{\circ}$, Germania - ppt. Hacklin.)

Längden af os humeri . . . . . . 40,0 m.m.

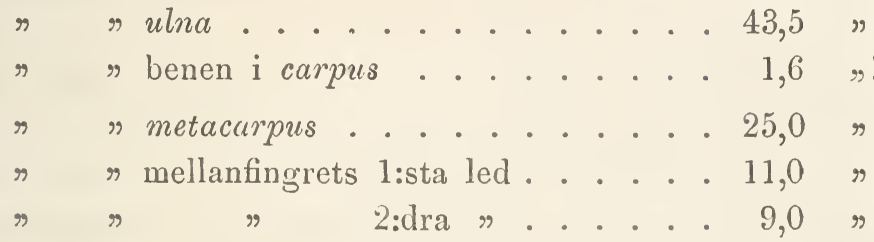

Hela handens längd . . . . . . . $\overline{45,0}$ \%

Afståndet från 1:sta bröstkotan till os coccygis . 68,0 \%

Längden af clavicula . . . . . . . 20,0 " . . . .

Minsta bredden af clavicula ....... . 2, 2,5

Tjockleken " $"$......... 2, 2,2 \%

Vinkeln emellan bågarna af furcula . . . . 90 ?

Största afståndet mellan bågarna af furcula . . 10,0 m.m.

Längden af sternum . . . . . . . 37,0 " . . . .

Minsta bredden af sternum . . . . . . 16,0 " . . .

Längden af crista sterni . . . . . . . . 37,5

Största höjden af crista sterni . . . . . 17,5 "

Höjden af crista sterni framtill . . . . . 16,0 "

Längrden af incisura sterni exterior . . . . 5, 5, "

Största bredden af incisura sterni exterior . . 3,0

Längden af incisura sterni interior . . . . 2,0

Största bredden af incisura sterni interior . . 2,5

62) Haematopus ostralegus L. - (Helsingf. - ppt. Hacklin.)

Längden af os humeri . . . . . . . 71,0 m.m.

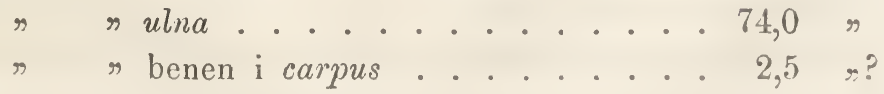


Längden af metacarpus 40,6 m.m.

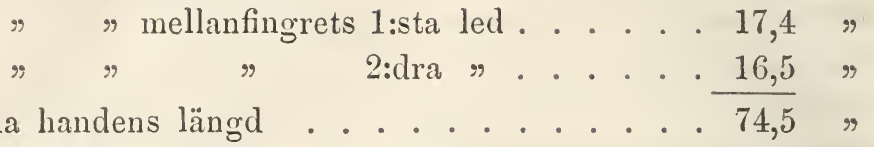

Hela handens längd Afståndet från 1:sta bröstkotan till os coccygis $112,5 \%$ Längden af clavicula . . . . . . . . 32,5 " Minsta bredden af clavicula ...... . . 3,0 " . . Tjockleken " 3,0 "

Vinkeln emellan bågarna af furcula . . . . 1050?

Största afståndet mellan bågarna af furcula . . 19,0 m.m. Längden af sternum . . . . . . . 60,0 Minsta bredden af sternum . . . . . . 28,0 " Längden af crista sterni . . . . . . . 59,0 " . . . . . . Största höjden af crista sterni . . . . . 23,0 " Höjden af crista sterni framtill . . . . . 22,6 " Längden af incisura sterni exterior . . . . 16,0 " Största bredden af incisura sterni exterior . . 8,0 " Längden af incisura sterni interior . . . . 11,6 " Största bredden af incisura sterni interior . . 5,6 "

63) Limosa lapponica L. (rufa Briss.) - (Lapponia - d.d.Ehrström.) Längden af os humeri . . . . . . . 65,0 m.m.

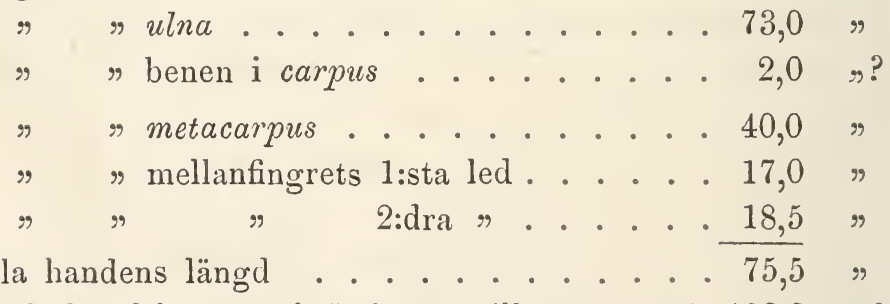

Afståndet från 1:sta bröstkotan till os coccygis 103,0 $\%$ ? Längden af clavicula . . . . . . . 29,5 " . . . . Minsta bredden af clavicula . . . . . . . . 3,5 Tjockleken " $"$. . . . . . 2, 2, Vinkeln emellan bågarna af furcula . . . $115^{0}$ ? Största afståndet mellan bågarna af furcula . . 14,0 m.m. Längden af sternum (def.) . . . . . . 43,0 $;$ ? Minsta bredden af sternum ..... . . 23,0 
Längden af crista sterni (def.).

Största höjden af crista sterni.

23,5 m.m.

Höjden af crista sterni framtill $23,5 \quad \%$

Längden af incisura sterni

Största bredden af incisura sterni

64) Machetes pugnax L. - (Germania, pr. Brandt - ppt. Hacklin.) Längden af os humeri . . . . . 54,5 m.m.

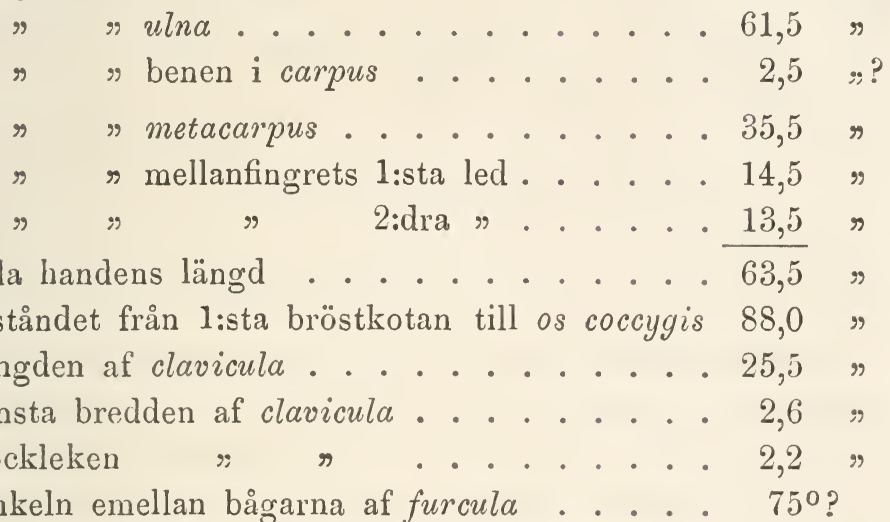

Hela handens längd . . . . . . . 63,5 "

Afståndet från 1:sta bröstkotan till os coccygis 88,0 " Längden af clavicula ....... 25,5 " . . 2 Minsta bredden af clavicula . . . . . 2, 2,6 "

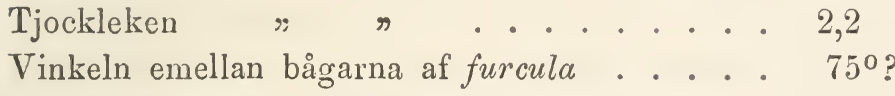

Största afståndet mellan bågarna af furcula . . 13,5 m.m. Längden af sternum ........ . . 54,0 " Minsta bredden af sternum . . . . . 20,5 " . . . . Längden af crista sterni ...... . . 54,0 " Största höjden af crista sterni . . . . 21,0 " Höjden af crista sterni framtill .... . 21,0 Längden af incisura sterni . . . . . . 17,0 " Största bredden af incisura sterni . . . . 7,5 "

65) Pelidna alpina L. - (Germania - ppt. Hacklin.)

Längden af os humeri . . . . . . 29,5 m.m.

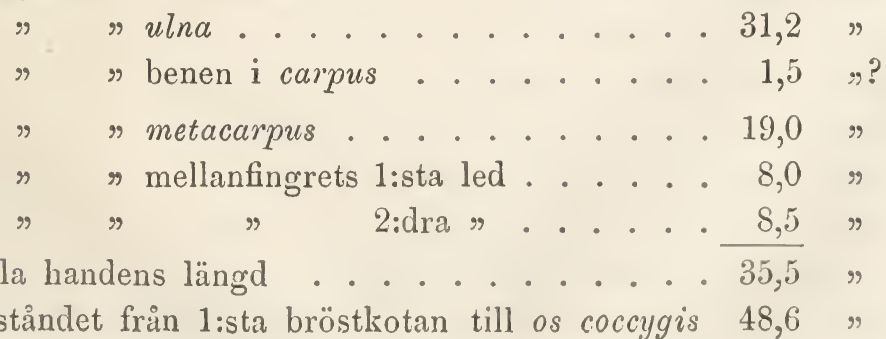

Afståndet från 1:sta bröstkotan till os coccygis 48,6 " 
Längden af clavicula 14,5 m.m.

Minsta bredden af clavicula

$1,8 \%$

$1,5 \%$

$90^{\circ}$ ?

Vinkeln emellan bågarna af furcula

Största afståndet mellan bågarna af furcula . . 8,7 m.m.
Längden af sternum . . . . . 29,0 r

Minsta bredden af sternum ....... 12,5

Längden af crista sterni . . . . . . 26,4 \%

Största höjden af crista sterni . . . . . . 12,0 „?

Höjden af crista sterni framtill . . . . . . 12,0 \%

Längden af incisura sterni exterior . . . . 6, 6,5 "

Största bredden af incisura sterni exterior . . 3,5 \%

Längden af incisura sterni interior . . . . 5,4

Största bredden af incisura sterni interior . . 4,5

66) Tringa canutus L. - (o', Germania - ppt. Hacklin.)

Längden af os humeri . . . . . . . 40,5 m.m.

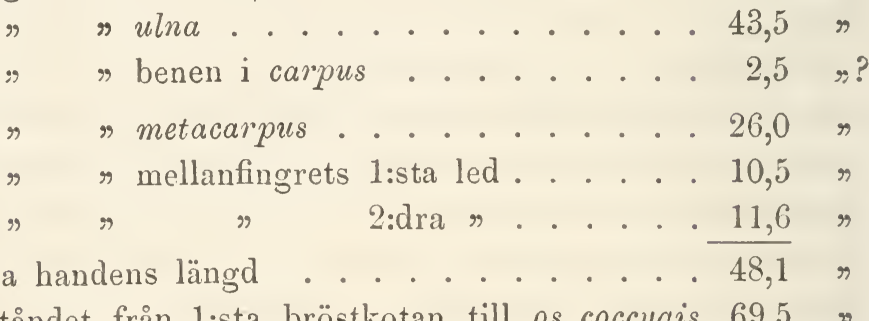

Afståndet från 1:sta bröstkotan till os coccygis 69,5 \#

Längden af clavicula . . . . . . . 19,2 "

Minsta bredden af clavicula . . . . . 2, 2,6 " . .

Tjockleken " $"$. . . . . . 2, 2, 0

Vinkeln emellan bågarna af furcula . . . . $75^{\circ}$ ?

Största afståndet mellan bågarna af furcula . . 11,0 m.m.

Längden af sternum . . . . . . . . 41,5 \%

Minsta bredden af sternum . . . . . . 17,0

Längden af crista sterni . . . . . . 40,0 " . . .

Största höjden af crista sterni . . . . . 16,0 "

Höjden af crista sterni framtill . . . . . . 16,0

Längden af incisura sterni exterior . . . . 11,5 "

Största bredden af incisura sterni exterior . . 6,7 \% 
Längden af incisura sterni interior 7,0 m.m. Största bredden af incisura sterni interior . . 3,5 r

67) Numenius phaeopus L. - (ㅇ, Helsingf. - ppt. Hacklin.)

Längden af os humeri . . . . . . . 74,0 m.m.

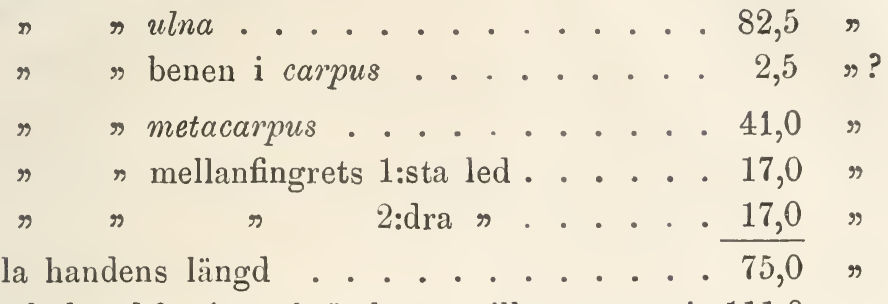

Hela handens längd ........ . . 75,0 "

Afståndet från 1:sta bröstkotan till os coccygis 111,0 "

Längden af clavicula . . . . . . . 31,2 "

Minsta bredden af clavicula . . . . . . 3,5 "

Tjockleken $"$ ". . . . . . . $3,0 \%$

Vinkeln emellan bågarna af furcula . . . 1050?

Största afståndet mellan bågarna af furcula . . 19,0 m.m.

Längden af sternum . . . . . . . 68,0 "

Minsta bredden af sternum . . . . . . 23,2 "

Längden af crista sterni . . . . . . 65,0

Största höjden af crista sterni . . . . . 27,0 "

Höjden af crista sterni framtill . . . . . 25,0 "

Längden af incisura sterni exterior . . . . 17,5 \%

Största bredden af incisura sterni exterior . . 7,0

Längden af incisura sterni interior . . . . 12,3 \%

Största bredden af incisura sterni interior . . . 6,0 "

68) Numenius arquata L. - (D.d. Hisinger.)

Längden af os humeri . . . . . . . 98,0 m.m.

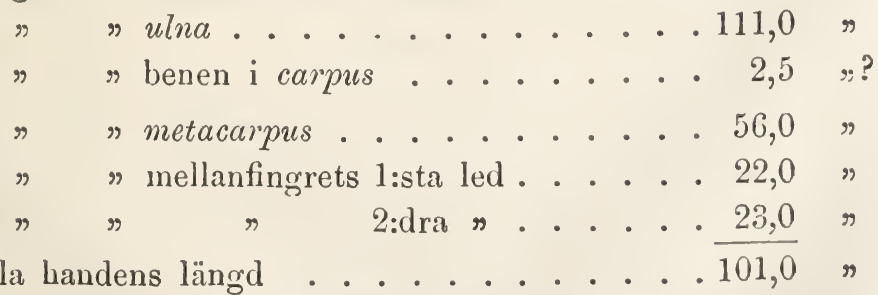

Hela handens längd . . . . . . . 101,0 n

Afståndet från 1:sta bröstkotan till os coccygis 152,0

Längden af clavicula ........ . . 41,0

(F. W. M-n V. 1867.) 
Minsta bredden af clavicula 4,2 m.m. Tjockleken 3,6 "

Vinkeln emellan bågarna af furcula . . . . 1050?

Största afståndet mellan bågarna af furcula . 24,0 m.m. Längden af sternum . . . . . . . 86,0 Minsta bredden af sternum ..... . . 31,0 " Längden af crista sterni . . . . . 85,0 Största höjden af crista sterni . . . . 33,0 " Höjden af crista sterni framtill . . . . . . 32,0 " Längden af incisura sterni exterior . . . 25,0 Största bredden af incisura sterni exterior . . 9,0 Längden af incisura sterni interior . . . . 17,0 " Största bredden af incisura sterni interior . . 8,0 " 69) Totanus (Glottis) glottis L. - $\left(\sigma^{2}\right.$, Helsingf. - d.d. Hirn.) Längden af os humeri . . . . . 50,2 m.m.

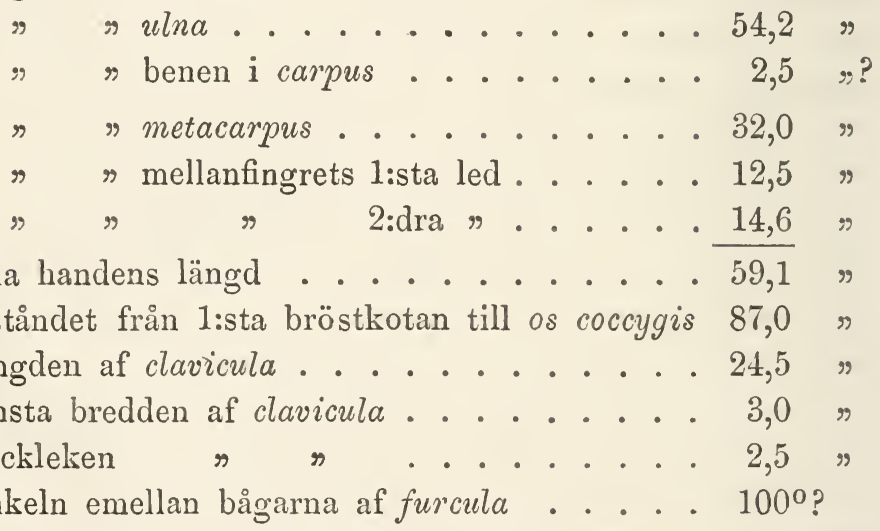

Hela handens längd ........ . . 59,1 "

Afståndet från 1:sta bröstkotan till os coccygis 87,0 "

Längden af clavicula ........ 24,5 " . . . .

Minsta bredden af clavicula ..... 3,0 ".

Tjockleken $\quad$ " . . . . . 2,

Vinkeln emellan bågarna af furcula . . . 100

Största afståndet mellan bågarna af furcula . . 11,6 m.m.

Längden af sternum . . . . . . . 52,0 "

Minsta bredden af sternum . . . . . 19,0 "

Längden af crista sterni . . . . . . 50,0 " . . .

Största höjden af crista sterni . . . . . 18,0 "

Höjden af crista sterni framtill ..... . . 17,5 "

Längden af incisura sterni exterior . . . . 17,4 "

Största bredden af incisura sterni exterior . . 6,5 "

Längden af incisura sterni interior . . . 4 4,5 n

Största bredden af incisura sterni interior. . 2,5 
70) Actitis hypoleucus L. - (Uskela - ppt. E. J. B.)

Längden af os humeri . . . . . . . 26,6 m.m.

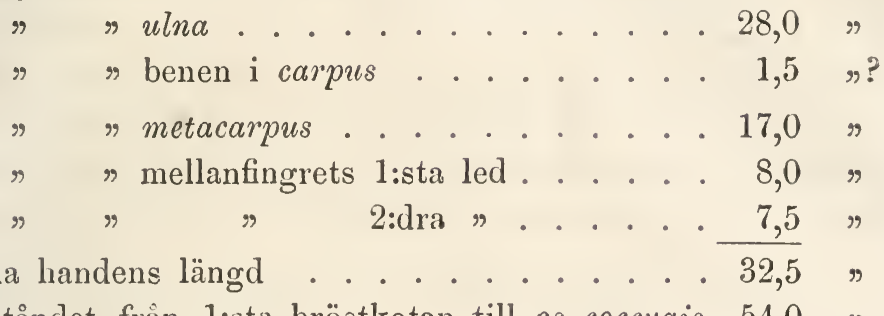

Afståndet fràn 1:sta bröstkotan till os coccygis 54,0 " Längden af clavicula . . . . . . . . 15,0 m.m.

Minsta bredden af clavicula ....... . 2,2 2 Tjockleken " $"$. . . . . . . 1,4 1,4

Vinkeln emellan bågarna af furcula . . . . 95\%?

Största afståndet mellan bågarna af furcula . . 7,4 m.m. Längden af sternum . . . . . . . 30,0 " . . . ( . . Minsta bredden af sternum . . . . . . . 11,0, ? Längden af crista sterni . . . . . . . . 28,0 " Största höjden af crista sterni. . . . . . 14,0 " Höjden af crista sterni framtill . . . . . . 13,6 m Längden af incisura sterni . . . . . . 8, 8,0 " Största bredden af incisura sterni . . . . . 3,5 \%

71) Scolopax rusticola L. - (Helsinge - ppt. Fagerström 1861.) Längden af os humeri . . . . . . . . 54,0 m.m.

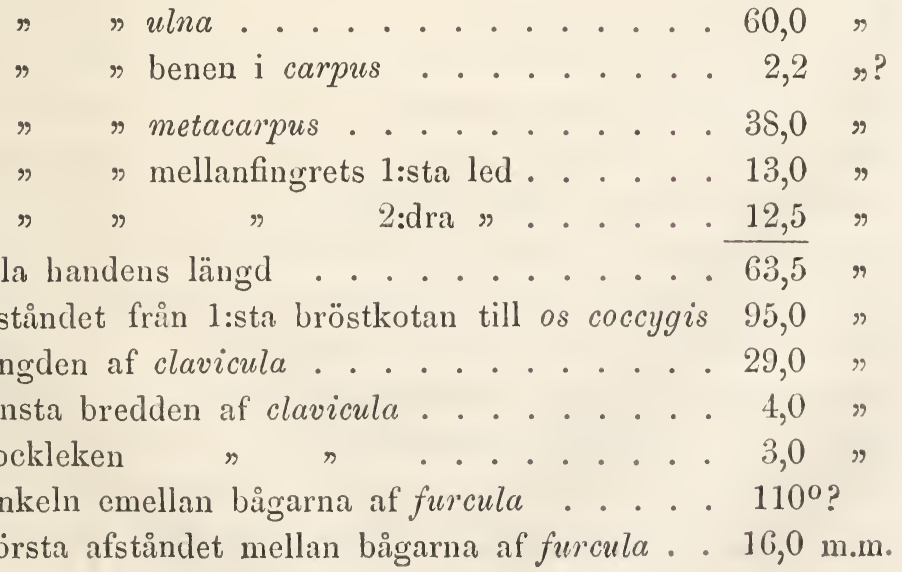


Längden af sternum

Minsta bredden af sternum 64,0 m.m.

Längden af crista sterni 22,0 川 Största höjden af crista sterni . . . . 25,0 Höjden af crista sterni framtill . . . . . 24,0 " Längden af incisura sterni . . . . . . 11,0 " Största bredden af incisura sterni . . . . . 3,5 "

72) Iscalopax (Gallinago) gallinula L. - (Germania - ppt. Hacklin.)

Längden af os humeri . . . . . . 31,0 m.m.

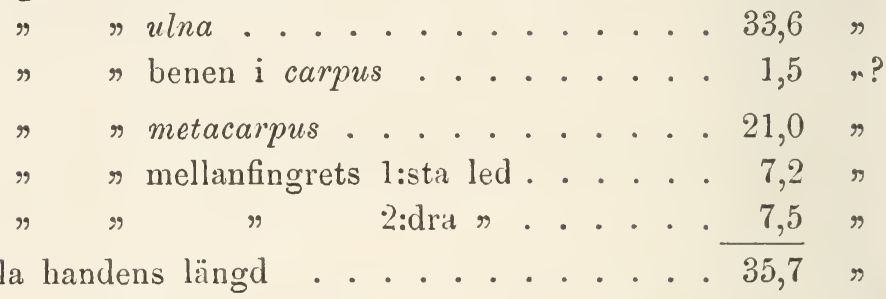

Hela handens längd . . . . . . . . 35,7 "

Afståndet från 1:sta bröstkotan till os coccygis 53,0 " Längden af clavicula . . . . . . . 15,5 " Minsta bredden af clavicula ...... 2,2 " Tjockleken $\quad " \quad \ldots . . .1 .1,5$ " Vinkeln emellan bågarna af furcula . . . $110^{\circ}$ ? Största afståndet mellan bågarna af furcula (afbruten) ? Längden af sternum . . . . . . 34,0 m.m.

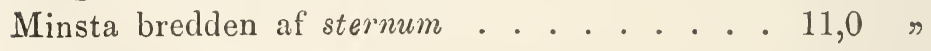
Längden af crista sterni . . . . . . . 34,0 " Största höjden af crista sterni . . . . . 14,0 " Höjden af crista sterni framtill . . . . . 14,0 " Längden of incisura sterni exterior . . . . 6 6,0 " Största bredden af incisura sterni exterior . . 3,0 Längden af incisura sterni interior . . . . 2, 2,6 n Största bredden af incisura sterni interior . . 1,5 »

73) Phalaropus lobatus L. (fulicarius L.) - (New Foundland.) Längden af os humeri . . . . . . 33,0 m.m. " " ulna $\ldots$ benen i carpus . . . . . . . . . . . . . 
Längden af metacarpus

20,6 m.m.

" "mellanfingrets 1:sta led . . . 8, 8,

,

"

r

$2:$ dra

$9,6 \%$

Hela handens längd

$38,8 \%$

Afståndet från 1:sta bröstkotan till os coccygis 55,0 "

Längden af clavicula

Minsta bredden af clavicula.

Tjockleken

$16,2 \%$

Vinkeln emellan bågarna aî furcula

2,0 \%

$1,4 \quad \cdots$

Största afståndet mellan bågarna af furcula . . 8,4 m.m.

Längden af sternum

30,0 \%

Minsta bredden af sternum . . . . . . 13,0 "

Längden af crista sterni . . . . . . 29,0 "

Största höjden af crista sterni . . . . . 11,4 "

Höjden af crista sterni framtill ..... . 10,5 》

Längden af incisura sterni exterior . . . . 6,5 "

Största bredden af incisura sterni exterior . . 4,0 "

Längden af incisura sterni interior . . . . 3,0 "

Största bredden af incisura sterni interior . . 2,2 "

74) Otis tarda L. - (Germania - ppt. C. Trapp.)

Längden af os humeri

. 171,0 m.m.

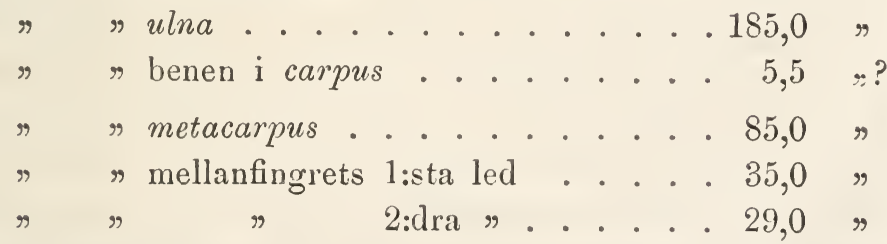

Hela handens längd . . . . . . . . $\overline{149,0}$ »

Afståndet från 1:sta bröstkotan till os coccygis 250,0 "

Längden af clavicula . . . . . . . . 71,0 "

Minsta bredden af clavicula ...... 8,5

Tjockleken $" \quad$ " . . . . . . 7,5 "

Vinkeln emellan bågarna af furcula . . . $75^{\circ}$ ?

Största afståndet mellan bågarna af furcula. . 37,5 m.m.

Längden af sternum

$125,0 \quad \%$

Minsta bredden af sternum . . . . . 60,0 " 
Längden af crista sterni . . . . . . . 125,0 m.m. Största höjden af crista sterni. . . . . . 44,0 " Höjden af crista sterni framtill . . . . . 41,0 " Längden af incisura sterni exterior . . . . 28,0 " Största bredden af incisura sterni exterior . . 11,5 " Längden af incisura sterni interior . . . . . 20,0 " Största bredden af incisura sterni interior. . . 14,0 "

75) Ortygonetra crex L. - (Uskela - ppt. E. J. B.) Längden af os humeri . . . . . . . . 46,2 m.m.

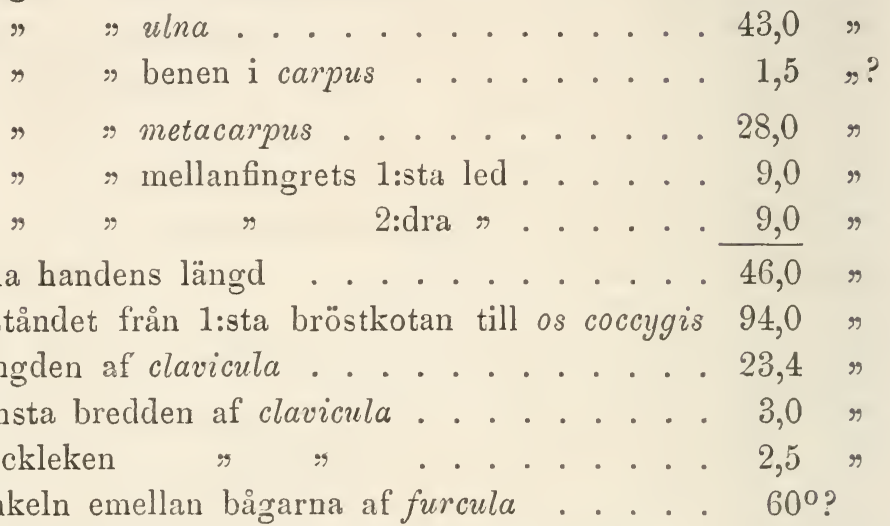

Största afståndet mellan bågarna af furcula . . 13,5 m.m.

Längden af sternum $40,0 \quad \%$

Minsta bredden af sternum . . . . . . . 9,4

Längden af crista sterni . . . . . . 39,0 " . . . .

Största höjden af crista sterni . . . . . . 15,0

Höjden af crista sterni framtill . . . . . 14,0

Längden af incisura sterni . . . . . . . 22,0 "

Största bredden af incisura sterni . . . . . 5,0 \%

76) Fulica atra L. - (Alandia - d.d. Tapenires, ppt. Hacklin.)

Längden af os humeri . . . . . . 75,0 m.m.

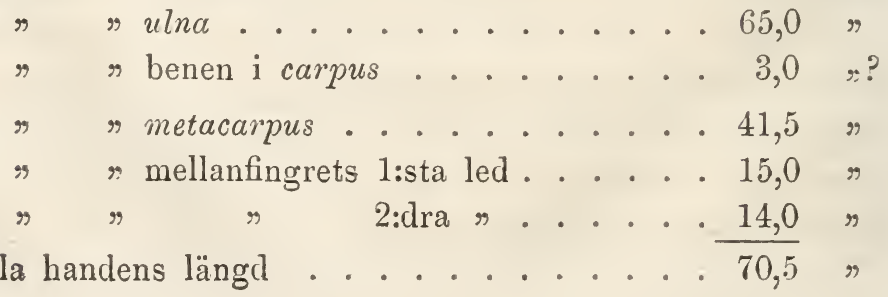

Hela handens längd ...... . . . 70,5 " 
Afståndet från 1:sta bröstkotan till os coccygis ?

Längden af clavicula . . . . . . . 33,5 m.m.

Minsta bredden af clavicula ....... . . 4, 4,

Tjockleken " $"$. . . . . . . 3,0 "

Vinkeln emellan bågarna af furcula . . . . $45^{\circ}$ ?

Största afståndet mellan bågarna af furcula . . 20,0 m.m.

Längden af sternum . . . . . . . . 58,0 " . . . .

Minsta bredden af sternum . . . . . . 19,0 "

Längden af crista sterni . . . . . . . 54,5 " . . . . . .

Största höjden af crista sterni . . . . . . 16,5 "

Höjlen af crista sterni framtill . . . . . 16,0 " . . . .

Längden af incisura sterni . . . . . . 35,0 "

Största bredden af incisura sterni . . . . 12,5

77) Larus fuscus L. - (D.d. V. Falck.)

Längden af os hrmeri . . . . . . . 123,0 m.m.

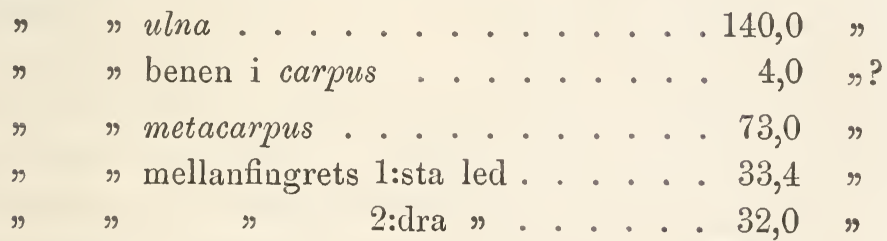

Hela handens längd ........ . . . . $\overline{138,4}$ "

Afståndet från 1:sta bröstkotan till os coccygis 138,0 "

Längden af clavicula . . . . . . . 50,0

Minsta bredden af clavicula . . . . . . 4, 4, . . . .

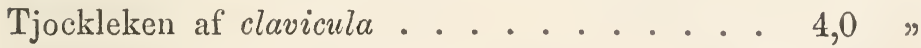

Vinkeln emellan bågarna af furcula . . . $80^{\circ}$ ?

Största afståndet mellan bågarna af furcula (af-

bruten) ......... . . 30,0 m.m.?

Längden af sternum . . . . . . . . 72,0 ". . . .

Minsta bredden af sternum . . . . . . 34,0 "

Längden af crista sterni . . . . . . . 73,0 "

Största höjden af crista sterni . . . . . . 25,5 "

Höjden af crista sterni framtill . . . . . 22,0 "

Längden af incisura sterni . . . . . . 10,0 n

Största bredden af incisura sterni . . . . 7,0 \% 
78) Larus marinus L. - ( $\sigma^{\prime}$, Svecia - d. A. Malm, ppt. Helenius 1860.) Längden af os humeri . . . . . . . 161,0 m.m.

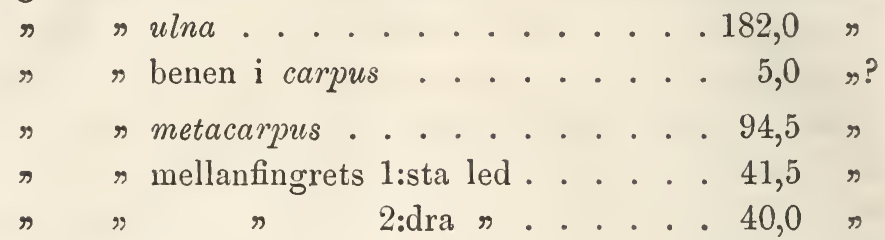

Hela handens längd 176,0 भ Afståndet från 1:sta bröstkotan till os coccygis 197,0 \% Längden af clavicula . . . . . . . 64,0 » Minsta bredden af clavicula...... . . 5,3 Tjockleken

Vinkeln emellan bågarna af furcula 4,7 \% Största afståndet mellan bågarna af furcula . . 46,0 m.m. Längden af sternum . . . . . . . 93,0 " Minsta bredden af sternum . . . . . . 47,0 \% Längden af crista sterni . . . . . . 88,5 \% Största höjden af crista sterni. . . . . 31,0 " Höjden af crista sterni framtill . . . . . 24,0 " Längden af foramen sterni (exterior) *) . . . 11,0 " Största bredden af foramen sterni (exterior) - 6,0 Längden af incisura sterni (interior) . . . . 11,0 Största bredden af incisura sterni (interior) . 11,0

79) Larus glaucus Brünn. - (Ppt. Renholm.)

Längden af os humeri . . . . . . 150,0 m.m.

" $\quad u \ln a$....................... 161,0

" benen i carpus ....... . . 4, 4,0 ?

" metacarpus ......... . . 84,0 ".

" mellanfingrets 1:sta led .... 36,0 " $\quad 2:$ dra $\%$.... 36,0 \% Hela handens längd . . . . . . . 156,0 " Afståndet från 1:sta bröstkotan till os coccygis 187,0 \%

*) Uppmätt pả högra sidan, hvilket här särskildt anmärkes, emedar detta hål icke är lika stort på den venstra. 
Längden af clavicula

61,0 m.m.

Minsta bredden af clavicula

5,2 \%

Tjockleken

$\rightarrow$

$4,5 \%$

Vinkeln emellan bågarna af furcula

Största afståndet mellan bågarna af furcula . . 45,5 m.m.

Längden af sternum

Minsta bredden af sternum

87,0 m

Längden af crista sterni

42,5 \%

Största höjden af crista sterni

84,0 \%

Höjden af crista sterni framtill

$31,0 \%$

Längden af incisura sterni exterior*) . . . . 12,0

Största bredden af incisura sterni exterior . . 3,6 "

Längden af incisura sterni interior . . . . 11,4

Största bredden af incisura sterni interior . . 11,6 "

80) Sterna hirundo Gmel. - (Uskela - ppt. E. J. B.)

Längden af os humeri

$56,0 \mathrm{~m} \cdot \mathrm{m}$.

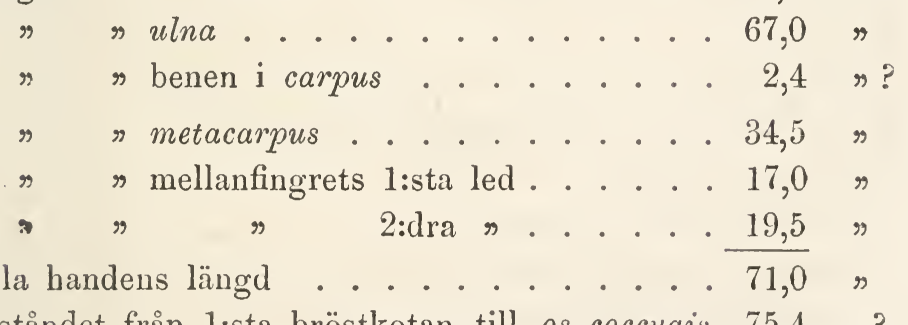

Afståndet från 1:sta bröstkotan till os coccygis 75,4 y?

Längden af clavicula . . . . . . . . 23,5 \%

Minsta bredden af clavicula . . . . . . . 2,4

Tjockleken $"$ " . . . . . . 2, 2, 2 . .

Vinkeln emellan bågarna af furcula . . . . $70^{\circ}$ ?

Största afståndet mellan bågarna af furcula . . 11,0 m.m.

Längden af sternum

$37,0 \quad \%$

Minsta bredden af sternum . . . . . . 18,0 "

Längden af crista sterni . . . . . . . . . . . . . . . .

Största löjden af crista sterni. . . . . 14,0 "

*) Alla dessa mâttbestämningar beträffande utskärningarna af bröst benet äro angifna efter fürhållandet på den högra sidan. Pâ den venstra sidan äro dessa incisurer märkbart olika. 
Höjden af crista sterni framtill $12,0 \mathrm{~m} \cdot \mathrm{m} . ?$

Längden af incisura sterni exterior . . . . 4 4,6 " Största bredden af incisura sterni exterior . . 3,0 ” Längden af incisura sterni interior . . . . . 5,2 " Största bredden af incisura sterni interior . . 3,0 "

81) Sterua hirundo Gmel. - (Q, Helsingf. - m. Maji 1855.)

Längden af os humeri . . . . . 50,0 m.m.

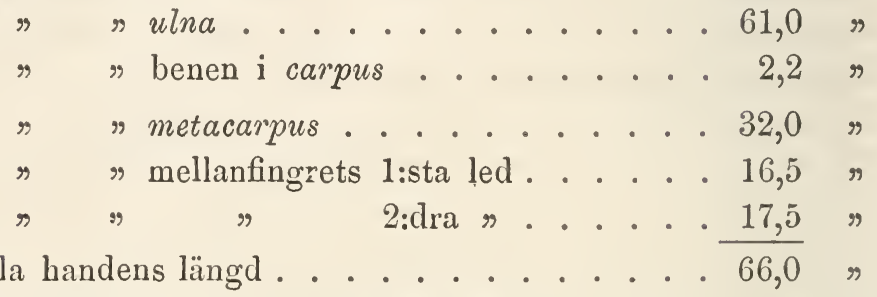

Afsti̊ndet från 1:sta bröstkotan till os coccygis 71,0 "

Längden af clavicula . . . . . . 23,0 "

Minsta bredden af clavicula ...... 2, 2, ". .

Tjockleken $" \quad$ " ....... 2, 2,0 "

Vinkeln emellan bågarna af furcula . . . . $60^{\circ}$ ?

Största afståndet mellan bågarna af furcula . . 11,0 m.m.

Längden af sternum . . . . . . . 33,0 "

Minsta bredden af sternum . . . . . . 17,0"

Längden af crista sterni . . . . . . . 31,0 " . .

Största höjden af crista sterni . . . . . 14,0 "

Höjden af crista sterni framtill ... . . . 11,0 "?

Längden af incisura sterni exterior . . . . 4 4,6 "

Största bredden af incisura sterni exterior . . 2,8 "

Längden af incisura sterni interior . . . . 3,0 "

Största bredden af incisura sterni interior . . ?

82) Lestris pomarina Temm. - (Helsing. - ppt. Hacklin.)

Längden af os humeri . . . . . . 109,0 m.m.

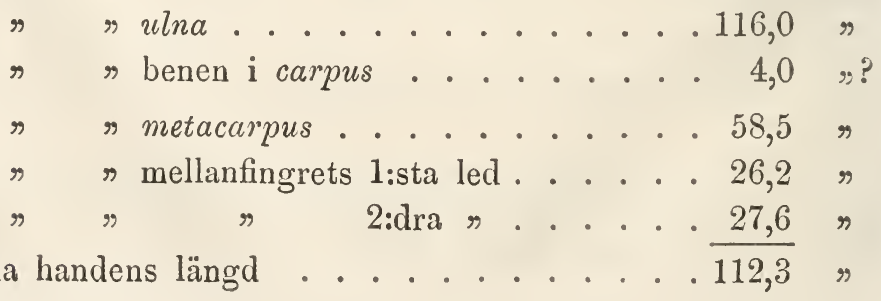

Hela handens längd . . . . . . . . . . . . 
Afståndet från 1:sta bröstkotan till os coccygis 125,0 m.m. Längden af clavicula $42,0 \quad \%$ Minsta bredden af clavicula .. . . . . . 4,0 " Tjockleken 4,2 "

Vinkeln emellan bågarna af furcula . . . . $75^{\circ}$ ?

Största afståndet mellan bågarna af furcula . . 29,0 m.m. Längden af sternum . . . . . . . 76,0 » Minsta bredden af sternum . . . . . . 35,0" Längden af crista sterni . . . . . . . 68,5 " . . . . . . . Största höjden af crista sterni . . . . . . 22,5 " Höjden af crista sterni framtill . . . . . 17,6 "? Längden af incisura sterni . . . . . . 19,6 " . . . . ( . . Största bredden af incisura sterni . . . . . 10,6 "

83) Diomedea exulans L. - (Ded. Sahlberg.)

Längden af os humeri . . . . . . . 392,0 m.m.

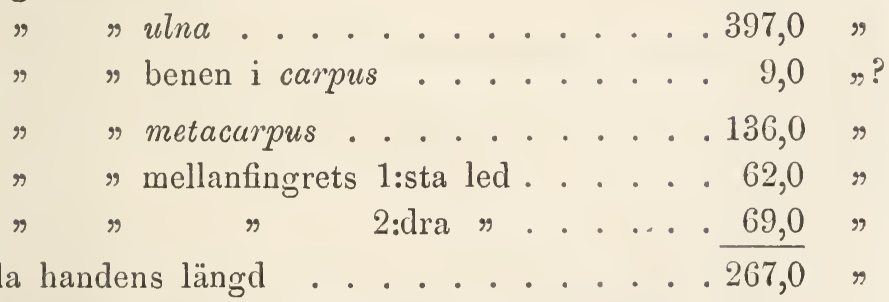

Hela handens längd . . . . . . . 267,0 Afståndet från 1:sta bröstkotan till os coccygis . 326,0 \% Längden af clavicula . . . . . . . 88,0 " . . . . . Minsta bredden af clavicula . . . . . 19,0 " Tjockleken " $\quad$ \% . . . . . . . 11,6 " . . . . . . . . Vinkeln emellan bågarna af furcula . . . . $100^{\circ}$ ? Största afståndet mellan bågarna af furcula . . 94,0 m.m. Längden af sternum . . . . . . . 127,0 " Minsta bredden af sternum . . . . . . 90,0" Längden af crista sterni . . . . . . . 92,0 $\%$ ? Största höjden af crista sterni . . . . . . 40,0" Höjden af crista sterni framtill . . . . . 36,0 " Längden af incisara sterni exterior (på högra sidan) *) . . . . . . . . . 14,0

*) $\mathrm{Pâ}$ venstra sidan nästan helt och hållet förbenad. 
Största bredden af incisura sterni exterior . . 12,0 m.m. Längden af incisura sterni interior . . . . . 4,0 " Största bredden af incisura sterni interior . . 14,0

84) Procellaria glacialis L. - (Norregia - ded. C. Sunderall.) Längden af os humeri . . . . . . 120,0 m.m.

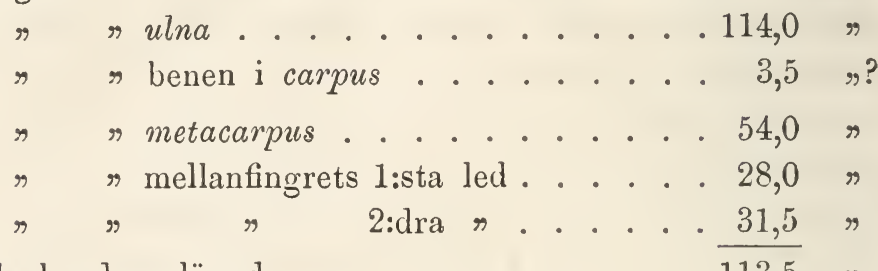

Hela handens längd . . . . . . . . . 113,5 "

Afståndet från 1:sta bröstkotan till os coccygis 142,0 \% Längden af clavicula . . . . . . 42,0 " Minsta bredden af clavicula ..... . 6,5 Tjockleken $\quad " \quad \ldots \ldots \ldots 3,6$. . . Vinkeln emellan bågarna af furcula . . . . $55^{\circ}$ ?

Största afståndet mellan bågarna af furcula . . 30,5 m.m. Längden af sternum ........ 5 . 57,0 Minsta bredden af sternum ..... . . 39,5 " Längden af crista sterni ....... . . 51,0 Största höjden af crista sterni . . . . . . 23,0 " Höjden af crista sterni framtill . . . . . 23,0 " Längden af incisura sterni exterior . . . . 3, 3,0 Största bredden af incisura sterni exterior . . 5,0 " Längden af incisura sterni interior . . . . 4 4,0 Största bredden af incisura sterni interior . . 6,2 "

85) Pelecanus crispus Bruch. - (Aegyptus - d.d. Wallin.) Längden af os humeri . . . . . . . 335,0 m.m.

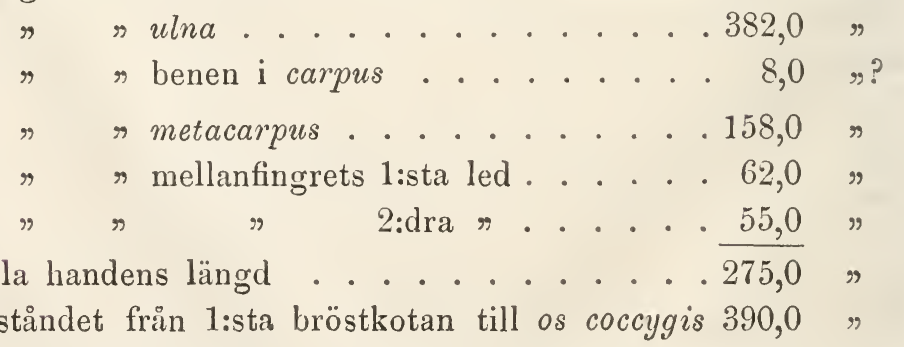


Längden af clavicula

141,0 m.m.

Minsta bredden af clavicula $20,0 \%$

Tjockleken

Vinkeln emellan bågarna af furcula 16,6 \%

Största afståndet mellan bågarna af furcula . . 99,5 m.m. Längden af sternum

Minsta bredden af sternum

Längden af crista sterni $90^{\circ}$ ?

Största höjden af crista sterni. $155,0 \quad \because ?$

Höjden af crista sterni framtill 102,0

Längden af incisura stẹrni . . 99,0 \%

Största bredden af incisura sterni

86) Mlergus merganser L. - $\left(\sigma^{7}\right.$.)

I ängden af os humeri

52,5 \%

46,4 \%?

20,0 »

46,0 \%

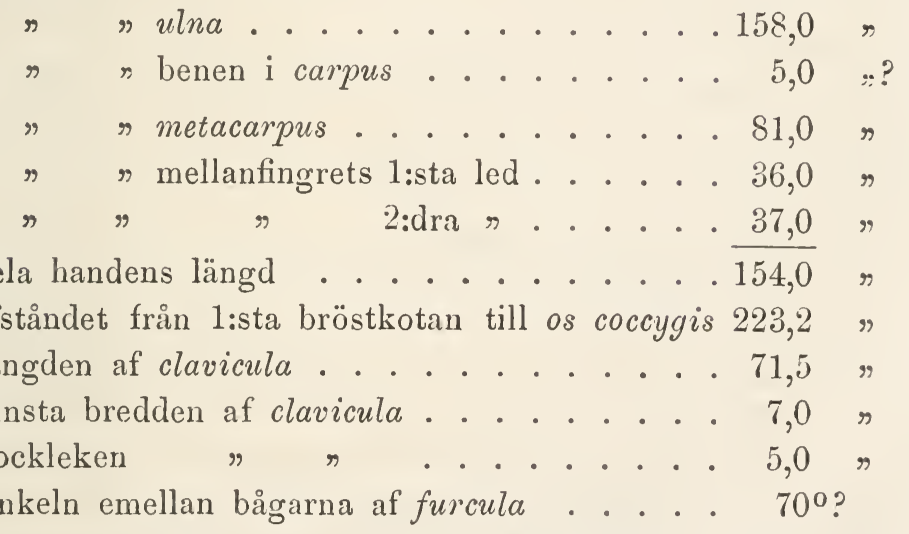

Största afståndet mellan bågarna af furcula . . $43,5 \mathrm{~m} . \mathrm{m}$.

Längden af sternum . . . . . . . 107,0 \%

Minsta bredden af sternum . . . . . . 48,5 \%

Längden af crista sterni . . . . . . . 97,0 " . . . . .

Största höjden af crista sterni . . . . . . 21,0 "

Höjden af crista sterni framtill . . . . . . ?

Längden af incisura sterni . . . . . . 25,0 \%

Största bredden af incisura sterni . . . . . 10,5 "

87) Mergus serrator L. -

Längden af os humeri ........ . 89,0 m.m.

" $\quad u \ln \alpha$

$75,0 \quad \cdots$ 
Längden af benen i carpus 4,0 m.m.?

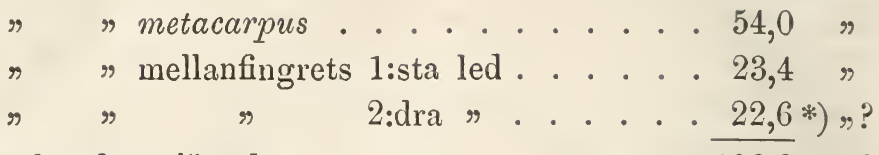

Hela handens längd . . . . . . . 100,0 »?

Afståndet från 1:sta bröstkotan till os coccygis 194,0 " Längden af clavicula . . . . . . 65,0 "

Minsta bredden af clavicula . . . . . 6, 6,

Tjockleken " $" \ldots \ldots . . .44,4$ "

Vinkeln emellan bågarna af furcula . . . $70^{\circ}$ ?

Största afståndet mellan bågarna af furcula . . 32,0 m.m.

Längden af sternum ......... . 86,0

Minsta bredden af sternum . . . . . . 42,0 "

Längden af crista sterni . . . . . . . 76,0 "

Största höjden af crista sterni . . . . 16,0 "

Höjden af crista sterni framtill . . . . . ? ${ }^{* *}$ )

Längden af foramen sterni ..... 21,0 m.m.

Största bredden af foramen sterni . . . . . 12,0 "

\section{8) Fuligula (0edemia) fusca L. -}

( $\sigma^{7}$, Helsinge - ppt. Fagerström 1861.)

Längden af os humeri . . . . . 103,0 m.m.

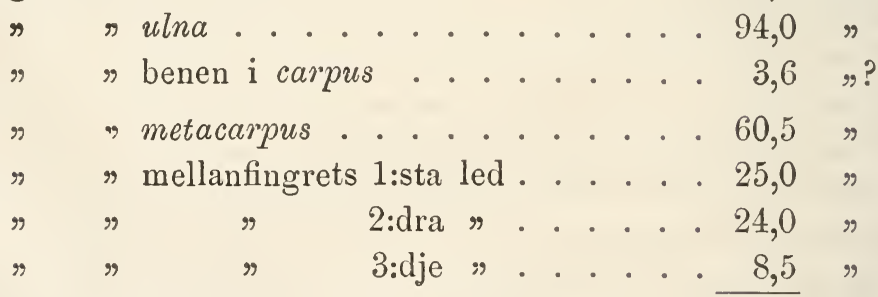

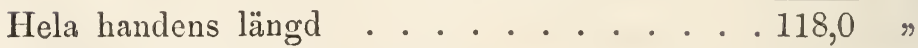

Afståndet från 1:sta bröstkotan till os coccygis 184,0 "

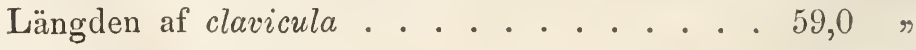

Minsta bredden af clavicula . . . . . 6, 6,6 "

Tjockleken $" \quad$ " ........ 5, 5,0

*) Denna fingerled är påtagligen afbruten.

**) Spetsen af crista sterni skjuter långt framom bröstbenets framsida. 
Vinkeln emellan bågarna af furcula . . . . $110^{\circ}$ ?

Största afståndet mellan bågarna af furcula . . 34,0 m.m.

Längden af sternum . . . . . . . . 97,0 \%

Minsta bredden af sternum ...... . . 53,0 "

Längden af crista sterni . . . . . . . . 92,0 " . . . . . .

Största höjden af crista sterni . . . . . . 28,0 "

Höjden af crista sterni framtill . . . . . 28,0 "

Längden af incisura sterni . . . . . . . 34,5 "

Största bredden af incisura sterni . . . . 18,0

\section{9) Fuligula (Clangula) clangula L. -}

Längden af os humeri . . . . . . 79,0 m.m.

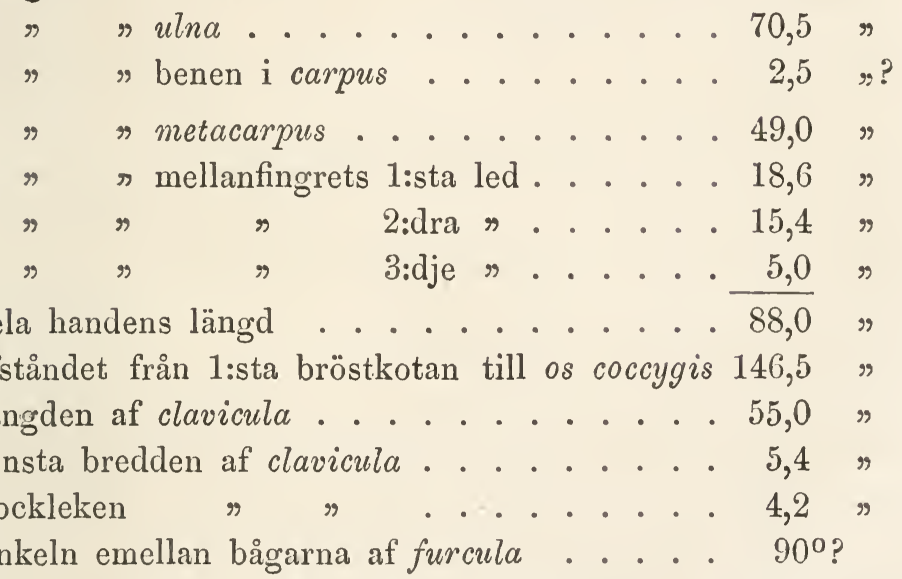

Största afståndet mellan bågarna af furcula . . 29,5 m.m.

Längden af sternum . . . . . . . . 84,0 "

Minsta bredden af sternum . . . . . . 4 41,0 "

Längden af crista sterni . . . . . . . 77,5 \%

Största höjden af crista sterni . . . . . . 20,6 "

Höjden af crista sterni framtill . . . . . . ? *)

Längden af foramen sterni . . . . . . 20,4 m.m.

Största bredden af foramen sterni . . . . 12,0 "

*) Spetsen af crista sterni skjuter lângt framom främre kanten af sternum. 
90) V'uligula (Somateria) spectabilis L. -

(ㅇ, Sitka - d.d. Holmberg 1859.)

Längden af os humeri . . . . . . . 103,5 m.m.

\begin{tabular}{|c|c|c|c|c|c|c|c|c|c|c|}
\hline$m$ & m & $\begin{array}{l}u \operatorname{lna} \cdot \cdot \cdot \cdot \\
\text { benen i carpu }\end{array}$ & $\begin{array}{l}\cdot \cdot \\
\text { us }\end{array}$ & $\begin{array}{l}\cdot \cdot \cdot \\
\cdot \quad \cdot\end{array}$ & & . & . & $\begin{array}{l}\cdot \cdot \cdot \\
. \\
\cdot\end{array}$ & $\cdot$ & $\begin{array}{r}94,0 \\
3,6\end{array}$ \\
\hline & r & metacarpus & . & . & • & . & . & & . & 65,0 \\
\hline & $\%$ & mellanfingrets & $1:$ sta & led & & . & . & & . & 24,0 \\
\hline & " & $\eta$ & 2:dra & $m$ & & . & & . & . & 21,0 \\
\hline & $\%$ & $\eta$ & 3:dje & $\eta$ & & & . & & & 6,6 \\
\hline
\end{tabular}

Hela handens längd . . . . . . . 116,6 "

Afståndet från 1:sta bröstkotan till os coccygis 200,0 \%

Längden af clavicula . . . . . . . 61,0 " . . .

Minsta bredden af clavicula . . . . . 7,0 \%

Tjockleken $\quad$ \% ...... . . 5,5

Vinkeln emellan bågarna af furcula . . . . 1050?

Största afståndet mellan bågarna af furcula . . 40,0 m.m.

Längden af sternum . . . . . . . 103,0 "

Minsta bredden af sternum . . . . . . 57,0 »

Längden af crista sterni . . . . . . . 95,0 "

Största höjden af crista sterni. . . . . 27,0 "

Höjden af crista sterni framtill . . . . 27,0 \%

Längden af incisura sterni . . . . . . . 40,0 " . .

Största bredden af incisura sterni . . . . 12,0 "

91) Anas (Querquedula) crecca L. - (ㅇ, Uskela.)

Längden af os humeri . . . . . . 56,0 m.m.

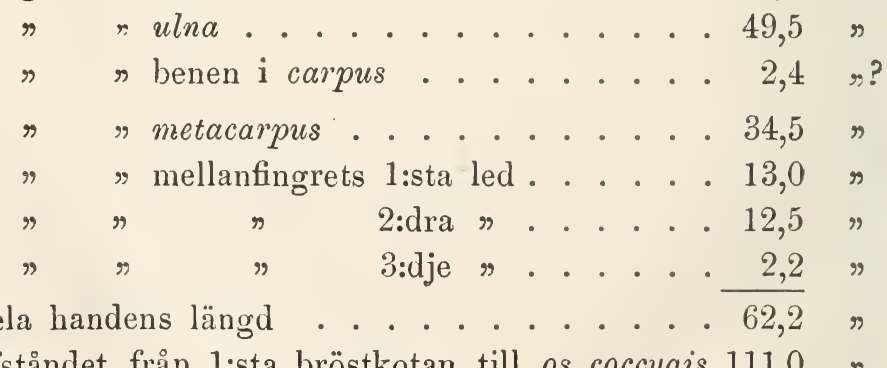

Afståndet från 1:sta bröstkotan till os coccygis 111,0 » Längden af clavicula . . . . . . . 33,0 " . . . . .

Minsta bredden af clavicula...... . . 3,0 " 
Tjockleken af clavicula 2,5 m.m.

Vinkeln emellan bågarna af furcula

Största afståndet mellan bågarna af furcula . 16,0 m.m.

Längden af sternum

54,0 ᄁ

Minsta bredden af sternum

$24,6 \%$

Längden af crista sterni . . . . . . . 56,0 \%

Största höjden af crista sterni . . . . . . 15,0

Höjden af crista sterni frantill . . . . . 15,0

Längden af incisura sterni . . . . . . . 17,0 》

Största bredden af incisura sterni . . . . 6, 6,4

92) Bernicla torquata Frisch. (Anser bernicla L.) -

(오 junior - ppt. Hacklin.)

Längden af os humeri

117,0 m.m.

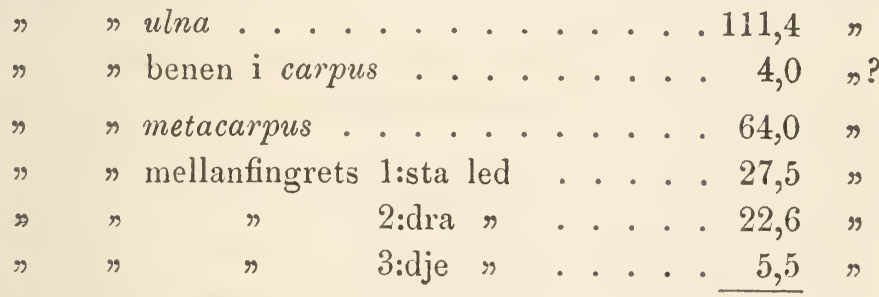

Hela handens längd ...... . . . . . 119,6 "

Afståndet från 1:sta bröstkotan till os coccygis 176,0 》 Längden af clavicula . . . . . . . 50,5 "

Minsta bredden af clavicula....... . . 7,0

Tjockleken $"$ ". . . . . . 6, 6, 6,0 ,

Vinkeln emellan bågarna af furcula . . . . $100^{\circ}$ ?

Största afståndet mellan bågarna af furcula . . 23,0 m.m.

Längden af sternum . . . . . . . . . 90,0 „?

Minsta bredden af sternum . . . . . . 4 43,5

Längden af crista sterni . . . . . . . 85,5 „?

Största höjden af crista sterni. . . . . . 29,5 "

Höjden af crista sterni framtill ...... . 28,5 \%

Längden af incisura sterni ....... . . 32,5

Största bredden af incisura sterni . . . . 16,0

93) Anser segetun Gmel. - (Germania - ppt. J. Hellström.)

Längden af os humeri . . . . . . . 163,0 m.m.

(F. W. M-n V. 1867.) 
Längden af $u \ln a$ 156,0 m.m.

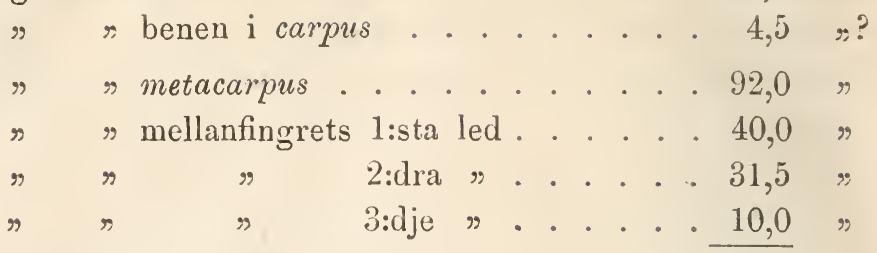

Hela bandens längd 173,5 \% Afståndet från 1:sta bröstkotan till os coccygis 257,0 " Längden af clavicula . . . . . . . 71,5 \% Minsta bredden af clavicula . . . . . . 9, 9, . . Tjockleken $"$ " . . . . . . . . 8, Vinkeln emellan bågarna af furcula . . . . . $120^{\circ}$ ?

Största afståndet mellan bågarna af furcula . . 38,0 m.m. Längden af sternum . . . . . . . . 132,0 \% Minsta bredden af sternum . . . . . . 57,5 " Längden af crista sterni . . . . . . 125,0 " . . . . . . Största höjden af crista sterni . . . . . . 38,0 \% Höjden af crista sterni framtill . . . . . . 36,0 " Länden af incisura sterni . . . . . . . . 41,0 " . . Största bredden af incisura sterni . . . . . 19,0 "

94) Cygnus musicus Bechst. (Anas cyguus Gmel.) (Helsinge - d.d. Appelgren.)

Längden af os humeri 292,0 m.m.

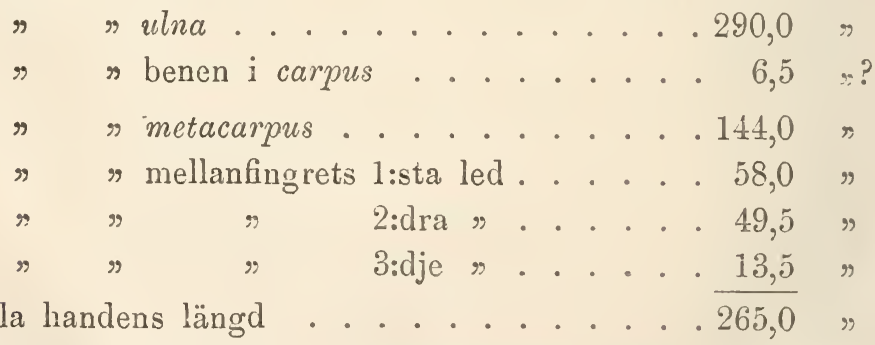

Afståndet från 1:sta bröstkotan till os coccygis 450,0 \% Längden af clavicula . . . . . . . 109,0 " Minsta bredden af clavicula....... 13,5 " Tjockleken " $\%$ $12,0 \%$

Vinkeln emellan bågarna af furcula 
Största afståndet mellan bågarna af furcula . . 59,0 m.m. Längden af sternum ......... 210,0 \% Minsta bredden af sternum . . . . . . 79,0 " Längden af crista sterni . . . . . . . 145,0, ? Största liöjden af crista sterni . . . . . 63,0 " Höjden af crista sterni framtill . . . . . . 56,0 " Längden af incisura sterni . . . . . . . 39,0 " Största bredden af incisura sterni . . . . . 16,0 \%?

95) Cygnus olor Gmel. - (Ppt. Fagerström.)

Längden af os humeri . . . . . . . 276,0 m.m.

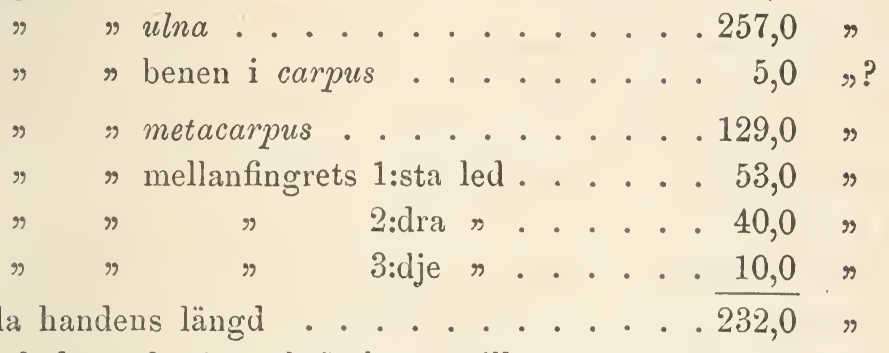

Afståndet från 1:sta bröstkotan till os coccygis 430,0 " Längden af clavicula . . . . . . . . 93,5 » Minsta bredden af clavicula . . . . . . 13,5 " Tjockleken " $\quad$. . . . . . 10,5 " Vinkeln emellan bågarna af furcula (afbruten) ? Största afståndet mellan bågarna af furcula . 71,0 "? Längden af sternum . . . . . . . . 185,0 " Mipsta bredden af sternum . . . . . . 84,0 " Längden af crista sterni . . . . . . . 166,0 " . . . . . . Största höjden af crista sterni . . . . . . 47,0 " Höjden af crista sterni framtill . . . . . 47,0 \% Längden af incisura sterni . . . . . . . 46,0 " . . Största bredden af incisura sterni . . . . . 21,0

96) Mormon glacialis Leach. - (Mus. Etholén.)

Längden af os humeri . . . . . . . 66,5 m.m.

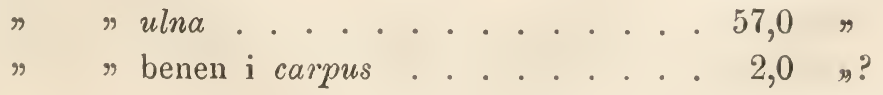


Läugden af metacarpus

37,4 m.m.

" mellanfingrets 1:sta led.... 17,0 "

\% $" 2:$ dra $\%$..... 19,0

Hela handens längd . . . . . . . . . 73,4 "

Afståndet från 1:sta bröstkotan till os coccygis 122,0 \%

Längden af c'avicula . . . . . . . 37,2

Minsta bredden af clavicula ...... 3, . . . . . ".

Tjockleken " $"$....... 3,0 "?

Vinkeln emellan bågarna af furcula . . . . $55^{\circ}$ ?

Största afståndet mellan bågarna af furcula . . 31,5 m.m.

Längden af sternum . . . . . . . . 85,0 " . . .

Minsta bredden af sternum . . . . . . 27,0 ".

Längden af crista sterni . . . . . . . 72,0 "

Största höjden af crista sterni...... . 25,0 "

Höjden af crista sterni framtill . . . . . . ?*)

Längden af incisura sterni (exterior) . . . 17,0 m.m.

Största bredden af incisura sterni (exterior) - 2,5 „?

Längden af foramen sterni (interior) . . . . 7,6**),

Största bredden af incisura sterni (interior) . 3,0 \%

97) Alca torda L. - (Helsinge.)

Längden af os humeri . . . . . . 79,0 m.m.

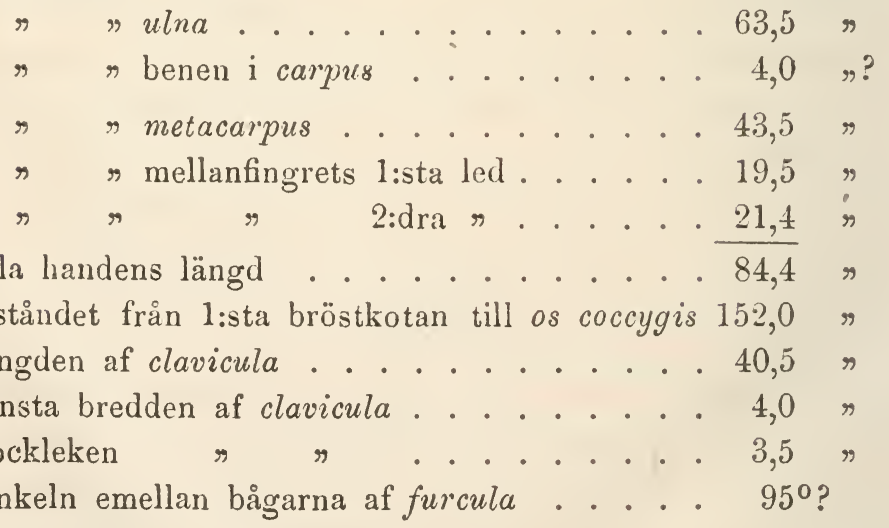

*) Spetsen af crista sterni skjuter långt framom främre kanten af sternum.

*) $\mathrm{P} ̊$ venstra sidan märkbart mindre. 
Största afståndet mellan bågarna af furcula . . 28,5 m.m. Längden af sternum . . . . . . . 103,0 Minsta bredden af sternum . . . . . 29,6 Längden af crista sterni . . . . . . . 89,0 Största höjden af crista sterni . . . . . 27,0 » Höjden af crista sterni framtill . . . . . ? *) Längden af incisura sterni . . . . . . 16,0 m.m. Största bredden af incisura sterni . . . . . 4,0

98) Uria grylle L. - (Helsinge.)

Längden af os humeri . . . . . . 63,0 m.m.

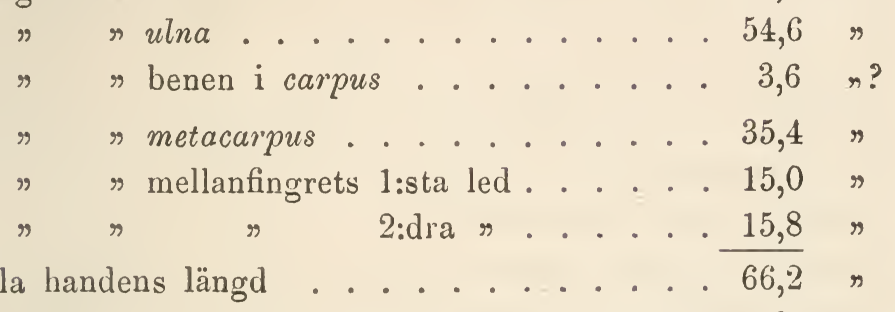

Afståndet från 1:sta bröstkotan till os coccygis ?

Längden af clavicula . . . . . . . 32,0 »

Minsta bredden af clavicula ...... . 3,6 "

Tjockleken " $\quad$ " . . . . . . 2 2,5 "

Vinkeln emellan bågarna af furcula . . . . $120^{\circ}$ ?

Största afståndet mellan bågarna af furcula . 26,0 m.m.

Längden af sternum . . . . . . . 994,0

Minsta bredden af sternum ...... . 29,5

Längden af crista sterni ...... . . . . . . . .

Största böjden af crista sterni ..... 21,0 n

Höjden af crista sterni framtill . . . . . ? **)

Längden af incisura sterni . . . . . 15,0 m.m.

Största bredden af incisura sterni . . . . 6, 6,0

99) Colymbus glacialis L. - (Norregia - ppt. Pippingsköld.)

Längden af os humeri . . . . . . . 192,0 m.m.

*) Spetsen skjuter framom sternum.

**) Spetsen af crista sterni skjuter mycket framom främre kanten af bröstbenet. 
Längden af ulna 155,0 m.m.

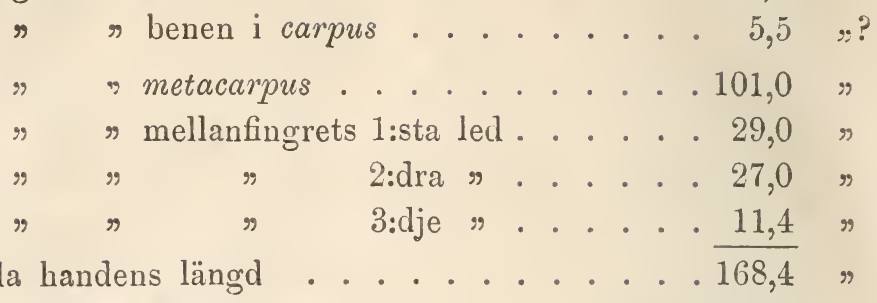

Afståndet från 1:sta bröstkotan till os coccygis 296,0 " Längden af clavicula . . . . . . . 74,0 " Minsta bredden af clavicula ....... . . 9,5 " Tjockleken " $"$. . . . . . 8,4 8

Vinkeln emellan bågarna af furcula . . . 50 ?

Största afståndet mellan bågarna af furcula . . 36,0 m.m.? Längden af sternum . . . . . . . . 172,0 s? Minsta bredden af sternum . . . . . 69,0 " Längden af crista sterni ...... . . . 143,0 " Största höjden af crista sterni . . . . . 34,5 " Höjden af crista sterni framtill . . . . . 34,5 " Längden af incisura sterni . . . . . . . 38,0 " Största bredden af incisura sterni . . . . 20,0

100) Podiceps subcristatus Gmel. (rubricollis Gmel., Lath.) (Helsingf. - ppt. Hacklin.)

Längden af os humeri . . . . . 9 98,0 m.m.

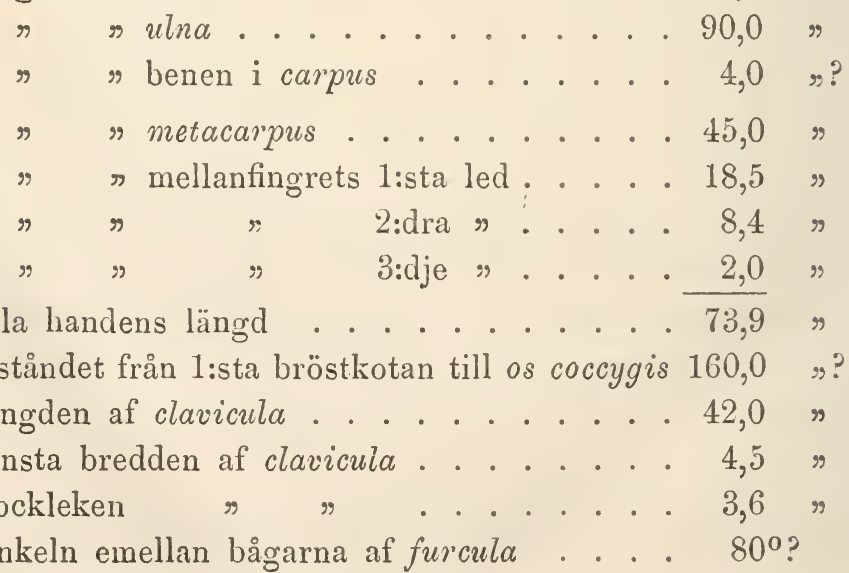


Största afståndet mellan bågarna af furcula . 30,0 m.m. *)

Längden af sternum . . . . . . 53,0 "

Minsta bredden af sternum . . . . . 39,0 "

Längden af crista sterni ... . . . . 56,4 "

Största höjden af crista sterni . . . . 21,5 "

Höjden af crista sterni framtill . . . . 22,0 "?

Längden af incisura sterni . . . . . 23,0 ”

Största bredden af incisura sterni . . . . 14,0 "

101) Spheniscus demersus L. - (Africa mer.? - ppt. Fagerström 1861.) Längden af os humeri . . . . . . . 72,0 m.m.?

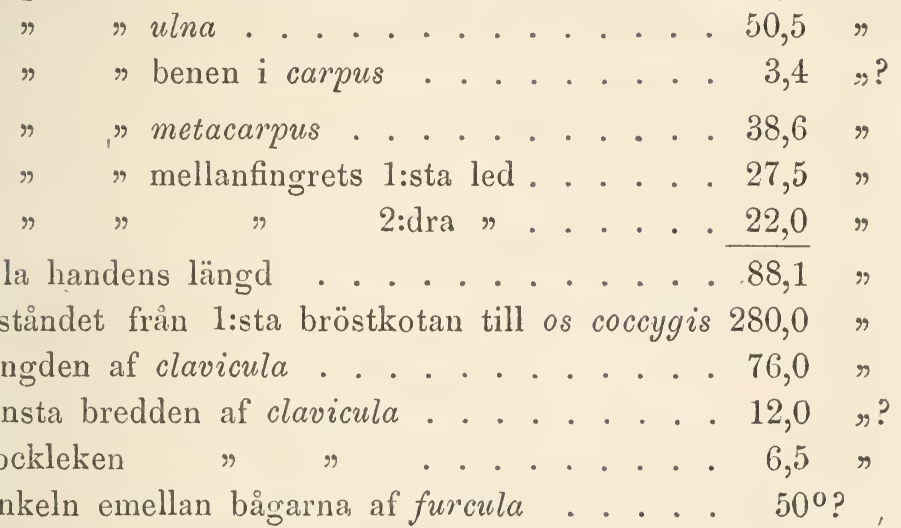

Största afståndet mellan bågarna af furcula . . 52,0 m.m. Längden af sternum . . . . . . . 115,0 "

Minsta bredden af sternum . . . . . . 52,0 "

Längden af crista sterni . . . . . . 113,0 "

Största höjden af crista sterni. . . . . . 31,0 "

Höjden af crista sterni framtill . . . . . ?

Längden af incisura sterni . . . . . . 55,0 m.m.

Största bredden af incisura sterni . . . . 12,0 "

102) Struthio camelus L. - (Exemplaret i zool. museum.)

Längden af os humeri . . . . . . 350,0 m.m.

$"$ "ulna..............122,0"

*) Hos denna art sträcka sig grenarna af furcula t. o. m. långt bakom processus coracoideus scapulae: ligamentum inter-claviculare mâste derföre här hafva en ännu större utsträckning än hos de flestil andra foglar. 
Längden af benen i carpus 5,0 m.m.?

" metacarpus. $88,0 \%$

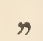

"mellanfingrets 1:sta led 39,0 "

" "

» 2:dra $"$

Hela handens längd . 151,0 \% Afståndet från 1:sta bröstkotan till os coccygis 1070,0 " Längden af clavicula. $98,0 *)$ ? ? Minsta bredden af clavicula Tjockleken

Vinkeln emellan bågarna af furcula 29,0 \% $15,0 \%$ $65^{\circ}$ ? Största afståndet mellan bågarna af furcula . 117,0 m.m. Längden af sternum . 240,0 ?? Minsta bredden af sternum . Längden af crista sterni 0,0 m.m. Största höjden af crista sterni . . . . . 0,0 " Höjden af crista sterni framtill . . . . . . 0,0 Längden af incisura sterni . . . . . . 38,0 " Största bredden af incisura sterni . . . . 29,0 "

Bland alla här anförda måttsbestämningar öfver dimensionerna af de ben, af hvilka en mer eller mindre utbildad flygförmåga hufvudsakligen måste vara beroende, böra onekligen de som beträffit vingbenen och hela truncus anses som de väsendtligaste, emedan de förra af dem ange sjelfva flygorganets proportionella byggnad och med ledning af de sednare utbildningen af detta organ i förhållande till kroppens storlek kan bestämmas. Vi hafva ofvanföre på grund af anställd jemförelse emellan flygförmågan hos skilda species anfört, att fogelarter, som utmärka sig genom en snabb eller skarp flygt, hafva öfverarmbenen proportionsvis korta i förhållande till de öfriga vingbenens sammanlagda längd, samt äfven försökt att

*) Det är nästan omöjligt att med nâgon säkerhet uppmäta nyckelbeuens längd, emedan dessa ben äro helt och hållet hopruxna med skulderbladet och gaffelbenet.

*) Afsmalnar småningom bakåt. 
ådagalägga den naturliga grunden för detta förhållande. Sid. 31 hafva vi jemväl yttrat att det synes antagligt, det förmågan af en mer eller mindre skarp flygt, såvidt den beror af vingbenens proportioner, kan uttryckas genom det tal, som man erhåller genom att dividera öfverarmbenets längd i den öfriga vingens. Såsom vi i det föregående genom några särskildt framhållna exempel visat, är likväl en lätt och sväfvande flygt mindre beroende af kraftiga vingslag, som i väsendtlig mån åstadkommas genom proportionsvis kortare öfverarmben, än af vingarnas hela längd i proportion till kroppens dimensioner. På grund häraf är det väl nödvändigt att vid uppskattandet af enskilda arters flygförmåga $\mathrm{i}$ förhållande till andras begge dessa här anförda omständigheter tillika tagas i beräkning, helst ganska många fogelarter utmärka sig på engång genom en snabb samt genom en lätt och uthållande flygt. För att bestämma vingarnas längd i förhållande till kroppens dimensioner, torde det vara lämpligast att dividera längden af truncus i det tal, som man erhåller genom en summering af samtliga vingbenens längd, emedan den erhållna qvoten genom detta förfarande blifver större för alla de arter, som utmärka sig genom en lättare och mera uthållande flygt. Då nu således, såsom vi nyss nämnde, begge dessa omständigheter, nemligen både öfverarmbenets längd i förhållande till de öfriga vingbenens samt hela vingens längd i förhållande till dimensionerna af truncus hvar för sig i väsendtligare mån bidraga till en utmärktare flygförmåga hos foglarna i allmänhet, bör man genom multiplicering af de begge onnämnda qvoterna erhålla relativa värden på de uppmätta exemplarens flygförmåga, såvidt densamina är beroende af vingarnas proportionella byggnad och deras längd i förhållande till kroppens storlek. Om man betecknar flygförmågan eller kanske rättare anlaget för en mer eller mindre utmärkt flygt med bokstafven $v$, öfverarmbenets längd med $h$, alla vingbenens sammanlagda längd med a samt längden af truncus med $t$, inne- 
fattas den af oss föreslagna beräkningen af skilda arters flygförmåga $\mathrm{i}$ formeln

$$
v=\frac{a-h}{h} \cdot \frac{a}{t} \text {. }
$$

Efter denna formel hafva vi beräknat värdet af qvantiteten $v$, som vi för korthetens skull benämna flygttalet, för hvart och ett af de 102 exemplar, hvilka vi uppmätt, och meddela här de tal, vi genom denna beräkning erhållit. För att tillika lemna en ofversigt af vingarnas utbildning hos de skilda arterna antingen för en snabb eller för en lätt och uthållande flygt, anföres $\mathrm{i}$ den första kolumnen det tal, som man erhåller genom att dividera öfverarmbenets längd $i$ de öfriga vingbenens, $i$ den andra deremot det tal, som erhålles genom att dividera längden af truncus i hela vingens längd, samt $\mathrm{i}$ den tredje kolumnen flygttalet $v$ eller produkten af dessa begge faktorer. Vi hafva ansett det lämpligt att genast uppställa de skilda arterna inom hvarje ordning, grupp och slägte efter flygorganets beräknade utbildning, hvarigenom den praktiska tillämpningen af dessa siffertal tillika antydes.

\section{Passeres.}

\section{a) Ilirundiniformes.}

1) Hirundo rustica L. . . . . . $3,88 \times 1,75=6,79$.

2) Chelidon urbica L. .... . 3,73 × $1,64=6,12$.

\section{ß) Corriformes.}

3) Monedula turrium Brehm. . . 2,65 × 2,02 $=5,35$.

4) Corvus corax L. . . . . 2, 2,49 $\times 2,14=5,33$.

5) " cornix L. ..... 2, 2,37 $\times 2,08=4,93$.

6) Pica *) caudata L. . . . . 2, $2,31 \times 1,94=4,48$.

7) Garrulus glandarius L. . . . 2,22 X1,69=3,75.

*) Detta slägte torde i sjelfva rerket sakna en användbar generisk benämning, ty namnet Pica är endast femininum af Picus, under hrilken benämning Lrxsé, såsom bekant, beskrifvit ett helt annat slägte. Namnet Cleptes Gambel deremot, som är accepteradt af CABAxis i Museum 


\section{v) Turdiformes.}

8) Turdus pilaris L. . . . . . $2,54 \times 1,74=4,42$.

9) Ampelis garrulus L. . . . . $2,61 \times 1,47=3,84$.

\section{8) Fringilliformes.}

10) Pinicola enucleator L. . . . $2,34 \times 1,53=3,58$.

\section{Zygodactyli.}

11) Cuculus canorus L. . . . . 2,15 × $1,93=4,15$.

12) Dryocopus martius L. . . . . $2,33 \times 1,65=3,84$.

13) Gecinus canus Gmel. . . . . $2,25 \times 1,56=3,51$.

14) $"$ viridis L. . . . 2, 24 ? $\times$ ? = ?

15) Picus medius L. . . . . 2,18 $\times 1,59=3,47$.

16) " leuconotus Bechst. . . . $2,19 \times 1,57=3,44$.

17) " major L. …. $2,21 \times 1,55$ ? $=3,43$ ?

18) " minor L. . . . . . $2,21 \times 1,55=3,43$.

19) Apternus tridactylus L. . . . . $2,12 \times 1,53=3,24$.

\section{Strisores.}

20) Cypselus apus L. . . . . . 5, 5,76 × $1,62=9,33$.

21) $\quad$. $\quad$. . . . . . $5,51 \times 1,59=8,76$.

22) Hypermetra gigas Vieill. . . 4,90 × $1,84=9,02$.

23) Caprimulgus europaeus L. . . . 2,59 ×2,67 $=6,92$.

\section{a) Valconidae.}

\section{Accipitres.}

24) Pandion haliaëtus L. . . . . $2,42 \times 3,42=8,28$.

25) Milvus regalis Briss. . . . . $2,21 \times 2,81=6,21$.

26) Aquila chrysaëtus L. o'? . . 2, $2,01 \times 2,88=5,79$.

27) $" \quad$ ㅇ?... . $2,08 \times 2,64=5,49$.

ornith. Heineanum och torde räkna sina vetenskapliga anor frân 1847 , kan ingalunda godkännas, emedan denna benämning är använd af $\mathrm{LA}_{\mathrm{A}}$ TREILLE för ett hymonopter-slägte redan 1804. Föröfrigt bör skatan bära benämningen pica som artnamn, emedan Lisxí endast under namnet Corvus pica beskrifvit ifrâgavarande species och aldrig under namnet $P$ ica caudata. För vår del skulle vi för deuna art föreslâ benämningen Gelastes pica. 
28) Haliaëtus albicilla L. . . . . 2,04 × 2,63 $=5,37$.

29) Hypotriorchis subbuteo L. . . $2,43 \times 2,33=5,66$.

30) Falco peregrinus? Lath. . . . $2,32 \times 2,16=5,01$.

31) Astur nisus L. . . . . . . 2,28 × 2,19=4,99.

32) $"$ palumbarius L. . . . 2,07 $\times 2,18 ?=4,51$ ?

33) Archibuteo lagopus Brünn. . . 2,10 × 2,63=5,52.

34) Buteo vulgaris Bechst. . . . $2,20 \times 2,37=5,21$.

35) Pernis apivorus L. .. . . . 2, $2,09 \times 2,36=4,93$.

36) Circus cyaneus L. . . . . . $2,23 \times 2,38=5,31$.

\section{ß) Vulturidae.}

37) Sarcoramphus*) gryphus L. . . $2,14 \times 2,92=6,25$. 38) Vultur fulvus Gmel. . . . . 2,15 ×2,92 $=6,28$.

\section{r) Strigidae.}

39) Nyctea nivea Thunb. . . . 2, $2,09 \times 3,00=6,27$.

40) " . . . 2, $2,08 \times 2,72=5,66$.

41) Bubo maximus Ranz. . . . . 2,06 ×2,83 $=5,83$.

42) " . . . . 2, $2,05 \times 2,71=5,56$.

43) Athene passerina L. . . . . 2,18 $\times 1,89=4,14$.

44) Syrnium uralense Pall. . . . 1,90 × 2,36 $=4,48$.

\section{Columbae s. Pullastrae.}

45) Columba livia Briss. var. domestica $2,77 \times 1,86=5,15$.

46) $\quad$ oenas L. ..... $2,71 \times 1,85=5,01$.

\section{Gallinae.}

c.) Phasianidae.

47) Pavo cristatus L. . . . . . $1,84 \times 1,89 ?=3,48$ ?

48) Numida meleagris L. . . . . $1,84 \times 1,34=2,47$.

49) Gallus domesticus Briss. . . . . 1,67 × $1,39=2,32$.

50) Gennaeus nycthemerus L. ․ . $1,83 \times 1,16 ?=2,12$ ?

*) Namnet Sarcoramphus Dumér. (Zool. anal. 1806) är bildadt af

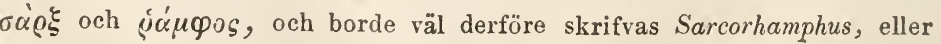
ännu hellre enligt lagen för grekiska ords sammansättning, Sarcorrhamphus. 


\section{ק) Tetraonidae.}

51) Tetrao urogallus L. . . . . $1,97 \times 1,59=3,13$.

52) $\quad$ hybridus L. . . . . $1,96 \times 1,59=3,12$.

53) $\gg$ tetrix L. . . . . $1,95 \times 1,53=2,98$.

54) Bonasa bonasia L. . . . . 1,92 X $1,39=2,67$.

55) Lagopus alba Gmel. . . . . 1,96 × 1,50 $=2,94$.

\section{Grallae.}

a) Herodiac.

56) Ardea cinerea L. . . . . . $2,09 \times 2,70=5,64$.

57) Ciconia alba Briss. . . . . 2, $11 \times 2,65 ?=5,59$ ?

58) Grus cinerea Bechst. . . . 2 $2,05 \times 2,28=4,67$.

ק) Charadriaceae s. Charadriadac.

59) Vanellus cristatus Mey. et W. . $2,27 \times 2,43=5,52$.

60) Strepsilas interpres L. . . . . $2,29 \times 1,92=4,40$.

61) Eudromias morinellus L. . . . $2,25 \times 1,91=4,30$.

62) Haematopus ostralegus L. . . 2,13 X $1,97=4,20$.

\section{y) Tringariae s. Scolopacidae.}

63) Limosa lapponica L. . . . . 2,32 X2,09? =4,85?

64) Machetes pugnax L. . . . . $2,34 \times 2,06=4,82$.

65) Pelidna alpina L. . . . . 2,31 $2,32,01=4,64$.

66) Tringa canutus L. . . . . . 2,32 X $1,93=4,48$.

67) Numenius phaeopus L. . . . $2,16 \times 2,10=4,54$.

68) $\quad \Rightarrow \quad$ arquata L. . . . $2,19 \times 2,05=4,49$.

69) Totanus glottis L. . . . . . $2,31 \times 1,91=4,41$.

70) Actitis hypoleucus L. . . . . 2,33 X $1,64=3,82$.

71) Scolopax rusticola L. . . . 2,33 X $2,89=4,40$.

72) Ascalopax gallinula L. . . . 2,28 X $1,92=4,38$.

73) Phalaropus lobatus L. . . . 2,23 X $1,94=4,33$.

\section{d) Alectorides.}

74) Otis $\operatorname{tarda} \mathrm{L}$.

$1,99 \times 2,04=4,06$

\section{ع) Rallinae s. Rallidae.}

75) Ortygometra crex I. . . . 1,96 X $1,44=2,82$.

76) Fulica atra L. . . . . . 1,85 X ? = ? 


\section{(c) Lougipennes.}

\section{Natatores.}

77) Larus fuscus L. . . . . . 2,30 $\times 2,93=6,74$.

78) $"$ marinus L. . . . . $2,26 \times 2,66=6,01$.

79) " glaucus Brünn. . . . 2,14 × 2,51 $=5,37$.

80) Sterna hirundo Gmel. . . . $2,51 \times 2,60 ?=6,53$ ?

81) " $"$. . . $2,58 \times 2,52=6,50$.

82) Lestris pomarina Temm. . . $2,13 \times 2,73=5,81$.

B) Tubinares.

83) Diomedea exulans L. . . . . 1,72 X3,27 $=5,62$.

84) Procellaria glacialis L. . . 1,93 X $2,47=4,77$.

v) Steganopodes s. Totipalmes.

85) Pelecanus crispus Bruch. . . 1,99 × 2,56=5,09.

d) Anatinae s. Lamellirostres.

86) Mergus merganser L. . . . . 2,23 × 2,05 $=4,59$.

87) " serrator L. . . . 2,01? X $1,38 ?=2,77$ ?

88) Fuligula fusca L. . . . . . 2,09 × 1,73=3,62.

89) $\quad$ clangula L.... . . 2,04 $\times 1,64=3,35$.

90) $"$ spectabilis L. . . $2,07 \times 1,59=3,29$.

91) Anas crecca L. . . . . 2, 2,04 X 1,53=3,12.

92) Bernicla torquata Frisch. . . 2,01 X2,00 $=4,02$.

93) Anser segetum Gmel. . . . . 2,05 X $1,90=3,89$.

94) Cygnus musicus Bechst. . . 1,92 X 1,89=3,63.

95) $\quad$ olor Gmel. . . . . 1,79 × $1,79=3,20$.

c) Pygopodes.

96) Mormon glacialis Leach. . . 1,99 X 1,63=3,24.

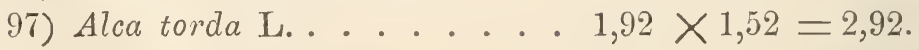

98) Uria grylle L. . . . . . 1,74 X ? = ?

99) Colymbus glacialis L. . . . 1,71 X1,76=3,01.

100) Podiceps subcristatus Gmel. . . 1,71 × 1,67?=2,86?

101) Spheniscus demersus L. . . . 1,97? × 0,76? $=1,50$ ?

\section{Proceres v. Cursores.}

102) Struthio camelus L. . . . $0,79 \times 0,58=0,46$. 
$\mathrm{Vi}$ anse oss uttryckeligen böra erinra derom, att dessa för hvarje art beräknade siffertal icke kunna betraktas såsom något absolut maitt på flyghastigheten, utan endast såsom värden, motsvarande flygorganets mer eller mindre ändamålsenliga byggnad för en utmärkt flygt, d. v. s. för en flygt, som är pæi engång snabb och lätt samt uthållande, och det är väl äfven sjelfva flygorganets högre eller lägre grad af utbildning, som vid dylika beräkningar hufvudsakligast bör tagas i betraktande. Flyghastigheten kan deremot vara beroende af flere andra omständigheter, såsom t. ex. af fogelns storlek äfvensom af den muskelstyrka, hvarmed vingslagen utföras. Sjelfva flyghastigheten hos foglarna kunde möjligen utrönas genom direkta iakttagelser, men ehuru kännedomen af densamma i och för sig skulle äga ett ganska stort intresse, kunde väl föga något för den systematiska uppställningen användbart resultat deraf vinnas. Hvad särskildt den vid flygten använda muskelstyrkan beträffar, hafva vi förut (sid. 35) uttalat den förmodan, att densamma står i förhållande till nyckelbenens mer eller mindre starka byggnad samt att man såsedes genom beräknande af den relativa styrkan af dessa ben hos skilda fogelarter bör erhålla värden, som motsvara den kraft, med hvilken vingslagen utföras. Nyckelbenen hos foglarna hafva icke någon regelbunden matematisk form, och det vore väl derföre ytterst svårt att hos hvarje särskild art med större noggranhet beräkna deras styrka, isynnerhet som musculus pectoralis major icke synes trycka emot dessa ben alldeles i samma riktning hos alla species. De närma sig till sin skapnad högst sällan ihåliga cylindrar men hafva vid en genomskärning i midten oftare en form, som närmar sig den af en triangel. Huru härmed än förhaller sig, tro vi att man kommer sanningen tillräckligt nära, om man antager, att nyckelbenens styrka står i direkt förhållande till genomskärningens yta och i omvändt förhållande till deras längd, eller ännu enklare; om man vid beräknandet af deras styrka multiplicerar den 
minsta bredden med tjockleken på samma ställe samt dividerar den erhållna produkten med benets största längd. Efter denna beräkning erhåller man såsom uttryck för den vid flygten använda muskelstyrkan t. ex. för Aquila chrysaëtus (오? N:o 27) talet 1,96, - för det andra exemplaret af samma fogel ( $\sigma^{7}$ ? N:o 26) 1,66, - för Haliaëtus albicilla 1,70, - för Sarcoramphus gryphus 1,84, - för Vultur fulvus 1,21, - för Pandion haliaëtus 0,75, - för Astur palumbarius 8,59, - för Astur nisus 0,32, - för Bubo maximus ( $\mathrm{N}: 0$ 42) 1,00, - för det andra (mindre) exemplaret af samma art (N:o 41) 0,79, - för Nyctea nivea (N:o 39) 0,94, - för det andra exemplaret af samma species (ㅇ, N:o 40) 0,83, - för Athene passerina 0,15, - för Corvus corax 0,38, - för C. cornix 0,29, - för Monedula turrium 0,19, - för Columba oenas äfvensom för C. livia v. domestica 0,31, - för Turdus pilaris 0,16, - för $\mathrm{H}_{i}$ rundo rustica 0,10 , - för Chelidon urbica 0,09, - för Larus marinus 0,39, - för L. fuscus 0,36 och för Sterna hirundo (N:o 81) talet 0,21. - Jemför man dessa siffertal med hvarandra, kan man genast finna, att den beräknade muskelstyrkan står $i$ en viss proportion till fogelns storlek, hvilket i sjelfva verket äfven måste vara förhållandet; ty det är väl naturligt, att den relativa muskelstyrkan hos djuren i allmänhet måste tilltaga med kroppens storlek. För att uttrjcka den vid utförandet af vingslagen använda muskelstyrkan hos hvarje särskild art med ett tal, som är oberoende af kroppens dimensioner, torde det äfven i detta fall vara lämpligast att dividera den på ofvan uppgifvet sätt beräknade muskelstyrkan med längden af truncus. Genom denna beräkuing erhåller man för den vid flygten användbara muskelkraften absoluta värden, hvilka tydligen variera från den ena arten till den andra, utan att derföre stå $\mathrm{i}$ någon proportion till kroppens storlek. Vi skola endast som exempel anföra att man sålunda erhåller både för Larus fuscus och Hirundo rustica talet 0,0026, för Larus marinus endast 0,0020 , för Lestris pomarina deremot 0,0032 . 
Såsom vi redan förut anmärkt, torde det blifva svårt att beräkna, till hvilken grad muskelstyrkan hos hvarje art kan bidraga till flyghastigheten, men om man förutsätter, att densamma hos närbeslägtade former, som till sin organiska byggnad mera öfverensstämma med hvarandra, befordrar en snabb flygt ungefär i samma proportion och man i öfverensstämmelse med detta antagande helt enkelt multiplicerar det funna värdet för muskelstyrkan med det beräknade flygttalet, erhåller man för Lestris pomarina och för Sterna hirundo (N:o 81) talet 0,019, för Larus fuscus 0,018 och för L. marinus talet 0,012 . Detta här vunna resultat synes vara af vigt för att rätt kunna förklara en känd egenhet i lefnadssättet hos arterna af slägtet Lestris. Nilsson säger om dessa fogelarter *): "De äro glupska, djerfva och tilltagsna. Deras föda består mest $\mathrm{i}$ fisk; men som de belt och bållet sakna simdykare-förmågan och äro dåliga störtdykare, s̊̊ kunna de ej sjelfva fånga mycket fisk $\mathrm{i}$ vattnet. De passa derföre på, då en annan vattenfogel, isynnerhet en Tärna eller Måse (bland hvilkas skaror de oftast uppehålla sig) fångat något rof; de angripa honom genast $i$ luften, knipa och hugga honom så länge tills han måste utkasta den stundom redan nedsväljda fisken, hvilken de då, med beundransvärd hastighet uppsnappa, innan han hinner vattnet eller jordytan". Då emellertid det af oss beräknade flygttalet för Lestris pomarina märkbart understiger det för Larus fuscus, Larus marinus och Sterna hirundo, vore det anmärkningsvärdt, att en fogel, som af naturen är begåfvad med proportionsvis mindre utmärkta anlag för en snabb flygt, är $\mathrm{i}$ stånd att plundra bytet af andra, som i förenämda afseenden öfverträffa den, om ej detta förbållande skulle finna sin förklaring i den öfvervägande muskelstyrkan hos den förstnämda arten. Det synes derjemte antagligt, att arterna af slägtet Lestris äfven på grund af sin mindre utbildade flygförmåga min-

*) Skandinavisk fauna, II, 2, sid. 354 och 355.

(F. W. M-n V. 1867.) 
dre lätt kunna uppsnappa fisk från vattenytan och derföre endast under en kortare tid till det yttersta anstränga sin större muskelkraft, för att af en fiskmåse eller tärna frånröfva dess fångade byte. Med anledning af detta här omtalade förhållande, anse vi äfven, att man vid uppskattandet af fogelarternas relativa flygförmåga $i$ allmänhet icke bör taga den vid utförandet af vingslagen användbara muskelstyrkan i beräkning, emedan ett endast för tillfället kanske ofta nog ända till öfveransträngning uppdrifvet anlitande af muskelkraften icke just bör räknas såsom några egentliga anlag för en utmärkt flygt. Endast i sådana fall, der det beräknade flygttalet är ungefär lika för skilda arter, bör, enligt vår åsigt, såsom vi äfven ofvanföre yttrat, en åtminstone betydligt öfvervägande muskelstyrka tagas $\mathrm{i}$ betraktande vid afgörandet af deras inbördes företräde i systemet. Vi skola i detta afseende anföra ett exempel. Det beräknade flygttalet för Sarcoramphus gryphus är 6,25 och för Vultur fulvus 6,28, och äfven denna ringa skilnad beror endast derpå, att förhållandet af öfverarmbenets längd till den öfriga vingens hos den förra ger talet 2,14 och hos den sednare 2,15. Det absoluta värdet för muskelstyrkan hos Sarcoramphus gryphus är enligt vår beräkning 0,0063, hos Vultur fulvus deremot endast 0,0043. Multiplicerar man dessa värden med flygttalen, erhåller man för den förra 0,039, för den sednare 0,027, och det är äfven på grund af denna öfvervägande muskelstyrka, som vi undantagsvis ställt kondoren framför sin samslägtinge, ehuru det beräknade flygttalet för den hvithöfdade gamen är litet större.

Att föröfrigt den vid flygten använda muskelstyrkan icke i samma proportion bidrager till flyghastigheten hos skilda arter, som tillhöra mindre affina grupper, kan t. ex. bevisas derigenom att man, om det absoluta värdet för muskelstyrkan multipliceras med flygttalet, erhåller för hafsörnen eller Haliaëtus albicilla talet 0,033, för ladusvalan eller Hirundo rustica deremot 0,018 och för hussvalan (Che- 
lidon urbica) endast 0,015, ehuru det är ganska säkert, att hafsörnens flyghastighet på intet sätt kan jemföras med svalornas, och det oaktadt denna roffogel derjemte är mångfaldiga gånger större än de sednast nämnda.

Öfverarmbenens längdförhållanden till den öfriga vingens dimensioner hafva vi hos några arter uppmätt på flere exemplar och dervid i allmänhet funnit, att detsamma åtminstone inom vissa grupper varierar ganska obetydligt. Större äro afvikelserna deremot både i förenämnda proportioner och $\mathrm{i}$ förhållandet af vingarnas längd till kroppens dimensioner hos individer inom alla sådana genera, der de skilda könen t. ex. i storlek betydligt afvika från hvarandra. För att faktiskt ådagalägga detta förhållande, hafva vi beträffande Aquila chrysä̈tus, Nyctea nivea och Bubo maximus här meddelat resultaterna af våra uppmätningar på tvenne exemplar af hvarje af dessa arter, hvilka exemplar troligen äro af olika kön. Redan af dessa få exempel synes det emellertid, att man vid en fullständig systematisering af fogelarterna inom de skilda grupperna efter lokomotionsorganernas utbildning nödvändigtvis måste beräkna medeltal efter förhållandet hos ett något större antal individer. - Den stora skilnad deremot, som visar sig i de beräknade flygttalen för de begge exemplaren af $C y$ pselus apus, bero säkerligen endast på den mindre grad af noggranhet, hvarmed vi varit $\mathrm{i}$ stand att uppmäta de fragila och genom omflyttningar under sednaste krigsoroligheter något skadade exemplaren af denna art. Emedan öfverarmbenen hos detta species äro ytterst korta i förhållande till den öfriga vingens längd, framkalla äfven mindre bråkdelar af millimetern vid uppmätandet af de skilda vingbenen naturligtvis högst betydliga afvikelser $\mathrm{i}$ de beräknade flygttalen.

Vid ordnandet af skilda species inom hvarje slägte äfvensom vid bestämmandet af den relativa platsen för hvarje genus inom de skilda grupperna, hafva vi här kunnat fästa afseende endast vid de af oss uppmätta arterna. 
Troligt är det derföre, att flygförnågan hos flere species, hvilka icke kommit i någon beräkning, skola förändra den systematiska ordningsföljden åtminstone inom några grupper*); men då vi i allmänhet bland dessa exempelvis frambållna former, såvidt det varit möjligt, utvalt sådana species, som äro mera framstående antingen genom en utmärkt eller genom särdeles tung och föga utbildad flygförmåga, torde de resultater, man vinner genom uppmätandet af flygorganet hos ett större antal arter, åtminstone ej i alltför väsendtlig mån omställa den af oss här endast efter ett mindre antal former beräknade ordningsföljden.

Vi skola nı öfvergå till betraktande af de öfriga enligt vår åsigt mindre väsendtliga måttsbestämuingarna, som här blifvit uppgifna för samtliga uppmätta arter. Beträffande den vinkel, som bildas af gaffelbenets bågar, hafva vi $\mathrm{i}$ det föregående redan uttalat vår åsigt om den betydelse, som bestämningar deraf kan hafva för hithörande undersökningar.

Då bröstbenet hos foglarna i allmänhet är af en ovanlig utbildning, är man föranlåten att förutsätta, det förhållandet emellan den minsta bredden af förenämnda ben och skulderpartiernas afstind från hvarandra, som vi trott oss kunna bestämma (likväl endast approximativt) genom uppmàtande af största af́ståndet emellan gaffelbenets bågar, står $i$ en viss proportion till flygförmågan hos skilda arter, och i sjelfva verket synes det vara fallet, att bröstbenets minsta bredu är betydligt större $\mathrm{i}$ förhållande till det omnämnda största afståndet mellan bågarna af furcula hos de flesta arter, som utmärka sig genom en öfvervägande

*) Sả kunde t. ex. Tachypetes aguilus L., hrars skelett vi ej varit $i$ tillfälle att uppmäta, màhända föranleda en omflyttning af Steganopodes framför Longipennes, om man ej sammanställer denna fogelart med representanterna af den sednast omnämnda gruppen. BoNAPARTE yttrar nemligen (Conspectus generum avium, II, p. 167) beträffande denna fogel: "Vix Totipalmus! Primus contra inter Longipenues!" 
flygförmåga. Det oaktadt hafva vi häruti ej kunnat upptäcka någon bestämd proportion, och det finnes några arter, som äro begåfvade med en ganska utmärkt flygt, Los hvilka bröstbenet till och med är smalare än det stōrsta afståndet emellan gaffelbenets bågar.

För att bevisa detta, torde det vara tillräckligt att här endast frambålla några fả exempel. Hos Numida meleagris är minsta bredden af sternum alldeles lika med stōrsta afståndet emellan bågarna af furcula och hos Gennaeus nycthemerus, som är begåfvad med en ännu sämre flygförmåga, är den minsta bredden af detta ben till och med 2 m.m. mindre än skulderpartiernas afstånd från hvarandra. Hos Chelidon urbica är den minsta bredden af bröstbenet jemt dubbelt större än afståndet emellan bågarna af gaffelbenet och hos Hirundo rustica, som utmärker sig genom en ännu snabbare flygt, är den minsta bredden af ifrågavarande ben $10,5 \mathrm{~m} . \mathrm{m}$. , största afståndet emellan gaffelbenets bågar deremot endast $4,0 \mathrm{~m} . \mathrm{m}$., således mindre än hälften deraf. Enligt N:o 20 har bröstbenet hos Cypselus apus, för hvilken vi, utan tvifvel i öfverensstämmelse med rerkliga förl.ållandet, beräknat det bögsta flygttalet, på långt när ej samma bredd i förhållande till skulderpartiernas inbördes afstand såsom hos svalorna, och hos tranan, hvilken t. ex. i jemförelse med hönsfoglarna är begåfvad med en ganska utmärkt flygförmåga, är den minsta bredden af mera nämnda ben endast $39,0 \mathrm{~m} . \mathrm{m}$., di deremot skulderpartiernas afstånd från hvarandra är 45,0 m.In.; hos den tama hönan är i motsats härtill minsta bredden af sternum 30,0 m.m. och största afståndet mellan gaffelbenets bågar endast 24,0 m.m. Olikheten $\mathrm{i}$ dessa proportioner beror onekligen $\mathrm{i}$ främsta rummet på bröstbenets variabla form hos skilda species. Af dessa här särskildt framhâllna fakta torde framgå, att uppgiften om skulderpartiernas afstånd frăn hvarandra $\mathrm{i}$ förhållande till bröstbenets bredd $\mathrm{i}$ allmänhet icke kan anتändas såsom någon säkrare grund vid beräknandet af fogelarternas relativa flygförmåga. 
Vi hafva i det föregående redan uttryckt vårt tvifvel om möjligheten att genom bestämningar öfver bröstbenets dimensioner kunna vinna en lika säker grund för bedömmandet af den vid flygten använda muskelstyrkan hos skilda arter som genom beräknandet af nyckelbenens styrka. Beräknandet af den väsendtligaste flygmuskelns vidfästningsyta skulle nemligen mötas af betydliga och nästan oöfverstigliga svårigheter. Ytan af sternum kunde visserligen åtminstone approximativt bestämmas. Man borde i sådant afseende multiplicera bröstbenets längd med dess medelbredd och ifrån den erhållna produkten subtrahera arealen af alla utskärningar eller hål samt till det sålunda erhållna talet lägga den beräknade ytan af crista sterni. Utskärningarna äfvensom bröstbenskammen kunde man i allmänhet anse som trianglar och således beräkna deras yta genom att multiplicera längden med halfva bredden eller halfva höjden. Hos sådana arter, der höjden af crista sterni är mindre framtill, än på något afstånd ifrån yttersta framkanten, borde man naturligtvis fästa tillbörligt afseende vid denna omständighet. Då man likväl, och det isynnerhet grenom ScHoEpss' noggranna undersökningar, ganska väl känner, att musculus pectoralis major icke är fästad öfver hela ytan af sternum och crista sterni samt att häri visar sig en betydlig olikhet hos skilda species, men att bemälde muskel deremot tillika utbreder sig öfver ligamentum interclaviculare och gaffelbenet, är det klart att man för beräknandet af denna muskels utbildning ganska noga borde känna förhållandet i förberörde afseende hos hvarje art och t. o. m. hos hvarje uppmätt individuum. Alla dessa omständigheter skulle säkerligen leda till högst invecklade och osäkra kalkyler, hvilka föga kunde vinna en praktisk användning, och det är med anledning häraf som vi anse det mycket enklare, att bedömma den vid utförandet af vingslagen användbara muskelkraften efter nyckelbenens styrka. 
Det ges en måttsbestämning beträffiande bröstbenets dimensioner, som inom somliga grupper itminstone i nödfall, t. ex. då vingbenen på ett skelett äro ofullständiga, synes kunna användas som en - visserligen ganska osäker grund för bedömmandet af den relativa flygförmågan hos mycket närbeslägtade former och isynnerhet hos arter, som höra till samma genus. Jemför man bröstbenet hos den afrikanska strutsen med detta ben hos andra foglar, som äro begåfvade med flygförmåga, är dess ringa längd i förhållande till kroppens dimensioner i ögonen fallande, och man lédes härigenom lätt på den tanken, att åtminstone längden af detta ben står $\mathrm{i}$ en bestämd proportion till flygförmågan hos foglarna. Dividerar man det på hvarje exemplar uppmätta afsti̊ndet från den första bröstkotan till os coccygis i bröstbenets längd, erhåller man för längden af sternum i förhållande till kroppens dimensioner absoluta värden, hvilka, såvidt det beträffar affina arter (och det inom flere grupper), i sjelfva verket på ett anmärkningsvärdt sätt öfverensstämma med de af oss för hvarje art och t. o. m. för skilda exemplar af samma species beräknade flygttal. Att denna proportion emellan bröstbenets längd och de beräknade flygttalen icke sträcker sig till mindre närbeslägtade former samt att t. ex. bland hönsfoglarna kunna uppvisas väsendtliga undantag ifrån denna regel, bör ej väcka någon förvi̊ning, då man ihågkommer, att hela formen af sternum är ytterst olika inom skilda grupper.

För att ådagalägga den omnämnda öfverensstämmelsen $\mathrm{i}$ förenämnda af́seende såvidt det beträffiar mycket affina arter och isynnerhet sådana species, som höra till samma slägten, skola vi här framhålla ett större antal exempel. Till underlättande af jemförelsen, anföras i den första kolumnen det för hvarje exemplar beräknade flygrtalet, i den andra deremot bröstbenets absoluta längd. 


\section{Hirundiniformes.}

\section{Passeres.}

1) Hirundo rustica L. . . . . . 6,79-0,44.

2) Chelidon urbica L. . . . . 6,12-0,39.

\section{Corviformes.}

3) Monedula turrium Brehm. . . . 5,35-0,45.

4) Corvus corax L. . . . . . 5,33-0,44.

5) $\gg$ cornix L. ..... 4,93-0,44.

\section{Turdiformes.}

8) Turdus pilaris L. . . . . . 4,42-0,52.

9) Ampelis garrulus L. . . . . 3,84-0,42.

\section{Zygodactyli.}

11) Cuculus canorus L. . . . . 4, 4, $15-0,51$.

12) Dryocopus martius L. . . . . 3,84-0,39.

13) Gecinus canus Gmel. . . . . . 3,51-0,39.

15) Picus medius L. . . . . . . 3,47-0,42.*)

16) $\gg$ leuconotus Bechst. . . . . 3,44-0,41.

18) " minor L. . . . . . . 3,43-0,40?

19) Apternus tridactylus L. . . . 3 3,24-0,39.

\section{Strisores.}

20) Cypselus apus L. . . . . . 9 9,33-0,52.

21) $\gg, \ldots . . .8,76-0,51$.

\section{Accipitres.}

24) Pandion haliaëtus L. . . . . 8,28 - 0,60.

26) Aquila chrysaëtus L. . . . . . 5,79-0,59.

27) $\gg \quad \ldots . . .5,49-0,55$.

*) De i båda kolumnerna här förekommande talen för genera Picus och t. ex. Gecinus förete en märkbar afvikelse; man bör härrid dock ihågkomma, att representanterna af förenämnda slägten äfren i lefnadssätt betydligt skilja sig från hvarandra. 
28) Haliaëtus albicilla L. . . . . . 5,37-0,53.

37) Sarcoramphus gryphus L. . . . 6,25-0,53.

38) Vultur fulvus Gmel. . . . . 6 6,28 - 0,56.

39) Nyctea nivea Thunb. . . . . 6,27 - 0,47.

40) $\gg \quad n \quad \ldots . .5,66-0,44$.

41) Bubo maximus Ranz. . . . . . 5,83-0,44.

42) $\gg \quad$. . . . 5,56-0,43.

44) Syrnium uralense Pall. . . . 4,48 - 0,39.

\section{Pullastrae.}

45) Columba livia Briss. var. domest. . 5,15-0,67. 46) $\gg$ oenas L....... 5, 5, 5,66 .

\section{Grallae.}

67) Numenius phaeopus L. . . . . 4,54-0,61. 68) $\gg$ arquata L. . . . . 4,49-0,57.

71) Scolopax rusticola L. . . . . 4,40-0,67.

72) Ascalopax gallinula L. . . . 4,38-0,64.

\section{Natatores.}

77) Larus fuscus L. . . . . . 6,74-0,52.

78) $\gg$ marinus L. . . . . 6,01-0,47.

79) Larus glaucus Brünn. . . . . . 5,37-0,47.

88) Fuligula fusca L. . . . . . 3,62-0,53.

89) $\rightarrow \quad$ clangula L. . . . $3,35-0,50{ }^{*}$ )

94) Cygnus musicus Bechst. . . . . 3,63-0,47.

95) $\quad$ olor Gmel. . . . . 3,20-0,43.

\section{Cursores.}

102) Struthio camelus L. . . . . . 0,46-0,22.

-) Hos Fuligula (Somateria) spectatilis L. är bröstbenets relativa längd litet större, nemligen 0,51 , ehuru det beräknade flygttalet endast är 3,23. 
Jemför man mindre närbeslägtade former med hvarandra, blifva afvikelserna i förenämnda afseende mera i ögonen fallande. Hos skatan t. ex., som visserligen bland annat genom sitt egendomliga sätt att flyga och hoppa betydligt skiljer sig från arterna af slägtet Corvus, är bröstbenets relativa längd densamma som hos kajan, ehuru skatan med afseende på flygförmåga betydligt står efter sist́nämnda fogelart.

Såsom en egendomlig afvikelse må anmärkas, att hos species af slägtet Tetrao ett alldeles motsatt förhållande synes äga rum beträffande bröstbenets längd än hos andra fogelarter. Man erhåller nemligen för

$$
\begin{aligned}
& \text { Tetrao urogallus L. . . 3,13 - 0,70. } \\
& \text { " tetrix L. . . . 2,98-0,75. } \\
& \text { Bonasa bonasia L. . 2, 2,67-0,77. }
\end{aligned}
$$

Di̊ den relativa längden af sternum hos de hönsartade foglarna $i$ allmänhet synes vara ovanligt stor, är det antagligt, att detta ben, som hos foglarna isynnerhet under flygten tjenar som ett nödvändigt stöd för kroppens inre temmeligen tunga organer och hos representanterna af denna ordning är särdeles djupt utskuret, tilltager i längd i samma proportion som det $\mathrm{i}$ öfrigt är mindre utbildadt. Jemför man nemligen inskärningarnas storlek på bröstbenet hos hjerpen med dem hos tjädern, skall man genast finna, att desamma hos den förra arten äro betydligt större i förhållande till kroppens dimensioner.

Inom de flesta grupper synes emellertid, att sluta af de ofvanföre framhållna exemplen, bröstbenets relativa längd hos affina arter tilltaga i samma förhållande som flygförmågan är mera utbildad och denna omständighet kan stundom i nödfall tjena till grund för hithörande beräkningar. - Här ett exempel. Af den i Europa ganska sällsynta Chlamydotis Macqueeni Hardw., Gray (Ind. zool.) förvaras i universitetets samling af inhemska fogelarter ett enda pa Drumsö vid Helsingfors skjutet exemplar, och alla de de- 
lar af skelettet, som icke varit nödvändiga till stöd för det uppstoppade exemplaret, finnas uppställda $\mathrm{i}$ anatomiska museum. I brist på ett fullständigt skelett af ifrågavarande art, äro vi nödsakade att beräkna dess flygförmåga efter det omnämnda fragmentet. Resultaterna af uppmätningen äro följande:

Afståndet från 1:sta bröstkotan till os coccygis 141,0 m.m. Längden af sternum Längden af clavicula Minsta bredden af clavicula ...... 5,4 Tjockleken

Bröstbenets relativa längd hos denna art är således 0,503. Hos den i Finland hittills lika sällan anträffade Otis tarda L. är den relativa längden af sternum, beräknad efter det af oss uppmätta exemplaret (N:o 74) 0,500. Det är med anledning häraf troligt, att den asiatiska kragetrappen eller Chlamydotis Macqueeni äger en mera utbildad flygförmåga och på grund deraf måste uppställas i systemet framför den såkallade stora trappen, isynnerhet som den vid flygten användbara relativa muskelstyrkan enligt vår beräkning hos den förra arten är 0,0039 , hos den sednare deremot endast 0,0036 .

I de flesta utförligare zoologiska handböcker framställes det vanligen nära nog som ett axiom, att höjden af bröstbenskammen hos foglarna står i ett direkt förhållande till deras flygförmåga. Tager man endast i betraktande, att en crista sterni saknas helt och hallet hos de strutsartade foglarna, hvilka alls icke kunna flyga, och att denna benkam deremot är sürueles hög hos åtskilliga arter, som äro utmärkta genom en utbildad flygförmigga, sisom t. ex. tornsvalan, kan man lätt förledas att instämma $\mathrm{i}$ den allmänna åsigten. Det är dock anmärkningsvärult att man icke fästat sig vid den omständigheten, att alla hönsfoglar, som äro kända för sin tunga flygt, äro särdeles köttrika p̊a framsidan af bröstet och det just till följe af bröstbenskammens stora höjd. 
För att kunna jemföra höjden af crista sterni hos skilda fogelarter, torde det vara lämpligt att dividera densamma med längden af bröstbenet eller ännu hellre med den af hela truncus. Genom det förra förfarandet erhåller man för bröstbenskammens höjd hos kungsörnen (enl. N:o 26) talet 0,21 och hos den tama hönan 0,27; enligt det sednare hos den förra arten 0,13 , hos den sednare deremot talet 0,17. I hvilket förhållande emellertid kungsörnens och hönans flygförmåga stå till hvarandra, känner hvar och en. För att $\mathrm{i}$ korthet visa, det den relativa höjden af crista sterni, ehurn den är ganska stor hos några utmärkta flygare, icke ens då kan användas som grund för beräknandet af fogelarternas flygförmåga när det är fråga om nära beslägtade species, är det nog att anföra några exempel. Dividerar man största höjden af bröstbenskammen med längden af sternum, erhålles för Hirundo rustica talet 0,39, för Chelidon urbica 0,44, för Corvus corax 0,32, för Corvus cornix 0,36, för Gelastes pica (Pica caudata) 0,34, för Cypselus apus 0,57, för Pandion haliaëtus 0,30, för Tetrao urogallus 0,32 , för Tetrao tretrix 0,32, för Bonasa bonasia 0,29, för Larus fuscus 0,35 , för Larus marinus 0,33 och för Larus glaucus talet 0,36. Divideras åter största höjden af crista sterni med längden af hela truncus, blir resultatet lika oförmånligt för hithörande beräkningar. Man erhåller nemligen sålunda för Hirundo rustica och Chelidon urbica talet 0,17, för Corvus corax 0,14, för Corvus cornix 0,16, för Gelastes pica 0,16, för Cypselus apus 0,30, för Pandion haliaëtus 0,18, för Tetrao urogallus 0,23, för Tetrao tetrix 0,24, för Bonasa bonasia 0,22, för Larus fuscus 0,18, för Larus marinus 0,12 samt för Larus glaucus talet 0,17. Hvar och en finner, att dessa tal ingalunda kunna representera flygförmågan.

Denna olikhet' af bröstbenskammens höjd beror onekligen på den egentliga flygmuskelns vidfästning på större eller mindre delar af bröstbenets mera horizontala del, pä bröstbenskammen eller på en del af refbenen o. s. v. Hos 
hönsfoglarna har crista sterni säkerligen en större höjd framtill af den orsak, att en större del af musculus pectoralis major härigenom kan finna ett fäste på närmare afstånd från os humeri. Genom denna organisation kan ifrågavarande muskel påtagligen inom kortare tid kontraheras och sålunda de tätare vingslagen utföras, som äro nödvändiga för dessa foglar, för att afhjelpa den för flygten mindre gynsamma byggnaden $\mathrm{i}$ örigt.

Beträffande utskärningarna och hålen på bakre sidan af bröstbenet gäller enligt vår öfvertygelse ungefär detsamma som om höjden af crista sterni, nemligen att man på grund af deras fullkomliga utevaro, större eller mindre antal och utsträckning $\mathrm{i}$ allmänhet icke kan draga några direkta slutsatser, som kunde användas vid beräkningen af fogelarternas flygförmåga. Det är visserligen fallet, såsom vi äfven ofvanföre uppgifvit, att dessa bål eller utskärningar alldeles saknas hos några utmärkta tlygare, men deremot enligt regel äro ganska stora hos si̊dana species, som äro kända för en mindre snabb eller lätt flygt; i sjelfva verket torde desamma likväl utöfva ett större inflytande på den vid flygten användbara muskelstyrkan än på sjelfva flygförmågan i öfrigt. Sålunda saknas t. ex. alla hål på bakre delen af bröstbenet hos kondoren, hvars muskelstyrka enligt vår beräkning är betydligt större än den hvithöfdade gamens; denna sednare art har deremot ett hål på hvardera sidan. Flere dylika exempel kunde anföras. Antalet af utskärningar eller hål på bröstbenet är föröfrigt mera karakteristiskt för enskilda grupper såsom man kan se af de i det föregående uppgifna måttsbestänningarua *).

I det föregående hafva vi framställt de hufvudsakligaste resultaterna af våra hittills anställda undersökningar öfver benbyggnadens användning såsom grund för beräknande af fogelarternas relativa flygförmåga. För att lemna

*) Se härom atförligare Starnius, Lehrb. d. vergl. Atrat. d. Wirbelth. p. 255 och Berthold, Beitr. s. Arat., Zootom. und Physiol. p. $10 j$ \&e. 
tillfälle ăt andra naturforskare att granska och måhända ytterligare förbättra de af oss använda beräkningsmethoderna, hafva vi ansett det nödvändigt att här så fullständigt som möjligt uppge dimensionsbestämningar öfver alla de ben, af hvilka enligt vår åsigt flygförmågan i väsendtligare afseende kan vara beroende. För vår del tro vi likväl det vara tillräckligt att $\mathrm{på}^{-}$hvarje skelett uppmäta endast vingbenens dimensioner, längden af truncus samt de förut uppgifna trenne dimensionerna af nyckelbenen, emedan man, såvidt vi kunnat finna, med ledning af måttsbestämningar öfver dessa delar i hvarje händelse vinner tillräckligt säker grund för beräknandet af de enskilda arternas anlag för en mer eller mindre utmärkt flygt.

Af farhåga att skada den utmärkta samling, som blifvit begagnad för dessa undersökningar, har jag icke velat fullständigt uppmäta ett större antal små foglar. Beträffande några Fringilliformes och Scansores samt slägtet Oriolus, om hvilkas olika systematiska placering i början af denna afhandling tillfälligtvis varit fråga, må här likväl meddelas åtminstone måttsbestämningar öfver längden af truncus samt af de på ett uppstäldt skelett lättare tillgängliga vingbenen.

103) Oriolus galbula L. - (Helsinge - d.d. A. Montin.) Längden af os humeri . . . . . . 30,5 m.m.

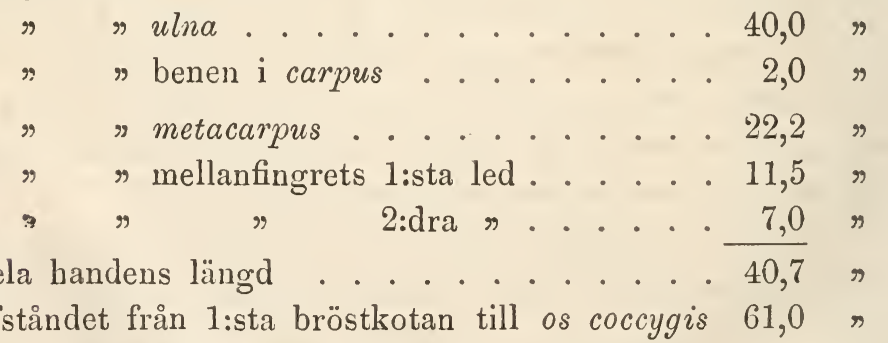

104) Loxia curvirostra L. - (Nylandia - d.d. Ekebom, ppt. E. J. B.) Längden af os humeri . . . . . . 19,0 m.m.

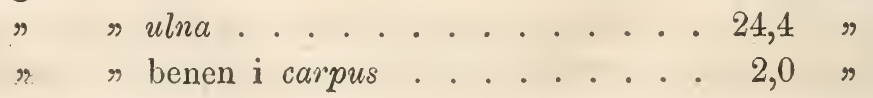


Längden af metacarpus . 13,4 m.m.

" mellanfingrets 1 :sta led .... 7,0 \%

" $" 2: d r a n \ldots . .3,0.3,0$

Hela handens längd . . . . . . . . . . $\frac{3,0}{23,4}$ "

Afståndet från 1:sta bröstkotan till os coccygis 42,0 "

105) Plectrophanes nivalis L. - (Helsinge - d.d. Ekebom, ppt.E.J. B.) Längden af os humeri . . . . . 20,0 m.m.

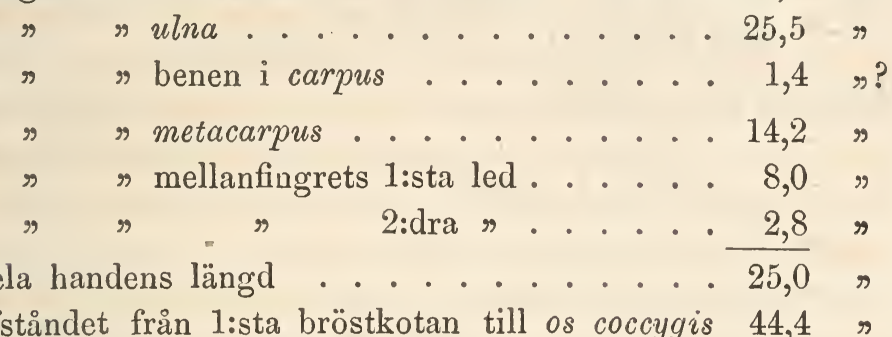
Afståndet från 1:sta bröstkotan till os coccygis 44,4 "

106) Jmberiza citrinella L. - (Ppt. E. J. B.)

Längden af os humeri . . . . . 21,6 m.m.

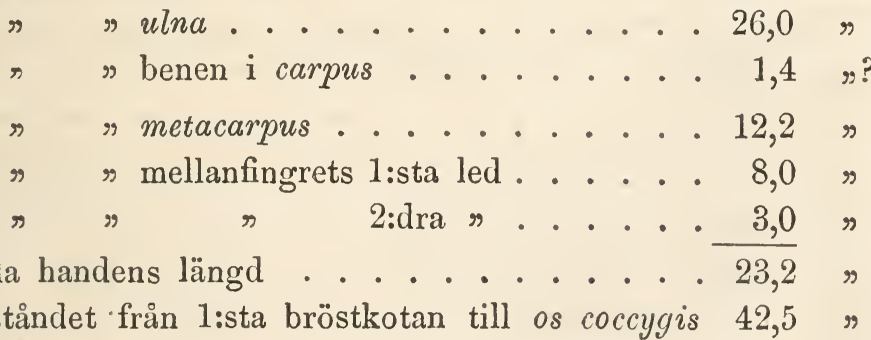

Hela handens längd . . . . . . . . . 23,2
Afståndet från 1:sta bröstkotan till os coccygis $42,5 \%$
107) Passer domesticus L. - ( 0 , Uskela - d.d. J. v. Wright.)
Längden af os humeri . . . . . . . . . 18,5 m.m.

Hela handens längd . . . . . . . . . 23,2 "
Afståndet från 1:sta bröstkotan till os coccygis 42,5 "
107) Passer domesticus L. - (o', Uskela - d.d. J. v. Wright.)
Längden af os humeri . . . . . . . . 18,5 m.m.

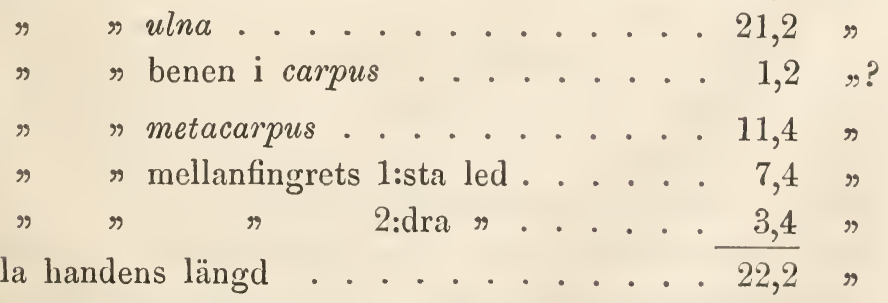

108) Certhia familiaris L. - (Helsinge - ppt. E. J. B.)

Längden of os humeri . . . . . 12,6 m.m. 
Längden af ulna 16,0 m.m.

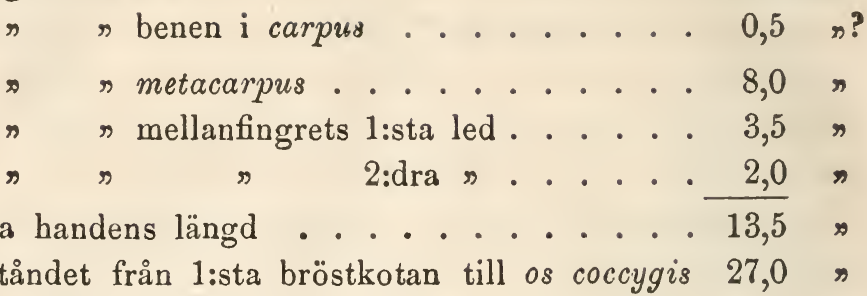

109) Sitta europaea L. - (ㅇ, D. C. Sundevall).

Längden af os humeri . . . . . . 18,6 m.m.

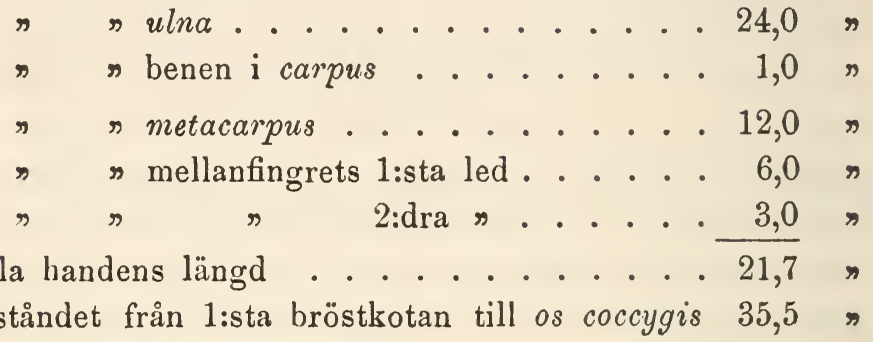

De efter den förut uppgifna formeln beräknade flygttalen blifva för

103) Oriolus galbula L. . . . . $2,71 \times 1,85=5,01$. 104) Loxia curvirostra L. . . . . $2,62 \times 1,64=4,30$. 105) Plectrophanes nivalis L. . . . $2,60 \times 1,62=4,21$. 106) Emberiza citrinella L. . . . . $2,35 \times 1,70=4,00$. 107) Passer domesticus L. . . . . $2,41 \times 1,51=3,64$. 108) Certhia familiaris L. . . . $2,38 \times 1,58=3,76$. 109) Sitta europaea L. . . . . 2, $2,51 \times 1,28=3,21$.

Att dömma af dessa flygttal, bör Oriolus galbula, om den föres till familjen Paradiseidae bland Corviformes, ställas näst efter slägtet Garrulus. - Bland Fringilliformes synes flygförmågan vara mest utbildad hos slägtet Loxia, derefter hos Plectrophanes och Emberiza, sedan hos Passer (Fringilla) och minst hos genus Pinicola (Pyrrhula). - Hvad slutligen Scansores beträffar, är flygförmågan hos representanterna af denna grupp visserligen mindre utbildad än hos Fringilliformes, men fäster man tillbörligt af- 
seende vid deras större affinitet med Turdiformes, måste dem väl anvisas en plats näst efter dessa.

Vid bristande tillgång på skeletter, kan den relativa flygförmågan hos arterna inom några mindre talrikt representerade slägten, till och med inom hela grupper åtminstone approximativt bedömmas efter de yttersta (främsta) handpennornas relativa längd. Det är lätt att inse att i samma mån, som de yttersta handpennorna äro förlängda, sjelfva vingen blir längre och dess skapnad mera gynsam för en god flygt*). Om man derföre uppmäter dessa handpennors skilnad i längd på samma exemplar, bör man efter olikheten häri hos skilda species kunna sluta till de jemförda arternas relativa flygförmåga. För att lemna niigra lämpliga exempel i detta afseende, gi̊ vi här att meddela skilnaden i de första handpennornas längd hos några Corviformes, hvilkas flygförmåga i det föregånde blifvit beräknad efter vingbenens inbördes proportioner och deras längd i förhallande till kroppens dimensioner. De ifrågavarande exemplaren förvaras såsom uppstoppade i universitetets zoologiska museum.

Honedula turrium Brehm. - (o', Esbo 18 ${ }_{4}^{1039}$.)

1:sta handpennan . . 66,5 m.m. kortare än den 2:dra. 2:dra "

$$
\text { . . } 20,0 \quad \%
$$

$\rightarrow$

$3:$ dje

" (den längsta)

4:de

5:te

$$
\text { .. } 13,0 \%
$$

6:te

$$
\begin{aligned}
& . .18,5 \text { r } \\
& . .17,0 \text { \% }
\end{aligned}
$$

längre
$r$
$r$

3:dje.

Corvus corax I. - (ㅇ, Kantua $\left.18_{1}^{847 .}\right)$

1:sta handpennan . . . 86,5 m.m. korture än den 2:dra. $2:$ dra
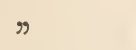

(1)

$3:$ dje

4:de

भ)

$"$ (den längsta)

19,0 \%

$\begin{array}{ccc}n & \Rightarrow & 3: d j e . \\ n & n & 4: d e . \\ \text { längre } & n & 5: t e .\end{array}$

*) Flere utmärkta flygare hafva likvăl den första handpenuan förkortad; hos svalorna saknas den alldeles. So härom utförligare i Sundevall's ofvan citerade arbete sid. $318-320$. 
5:te handpennan . . 59,0 m.m. längre än den 6:te. 6:te

$$
\text { , }
$$$$
\text { ... } 42,5 \% \text { " }
$$$$
\text { } 7: \text { :e. }
$$

Corrus cornix L. - ( $\sigma^{7}$, Helsingf. $18_{\frac{3}{3}}^{147}$.)

1:sta handpennan . . 85,5 m.m. kortare än den 2:dra.

\begin{tabular}{|c|c|c|c|c|c|}
\hline 2:dra & $"$ & & .... & 29 & \\
\hline 3:dje & " & & . . . & 8, & \\
\hline 4:de & $"$ & (den & längsta) & $5, \mathrm{C}$ & " \\
\hline :te & $\%$ & & $\therefore \cdot$. & $15,($ & $"$ \\
\hline 6:te & " & & . . . . & 49,0 & 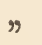 \\
\hline
\end{tabular}

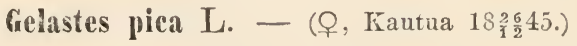

1:sta handpennan . . 61,5 m.m. kortare än den 2:dra.

\begin{tabular}{|c|c|c|c|c|c|c|c|}
\hline 2:dra & $\pi$ & & . . . . & 25,4 & " & 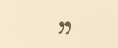 & 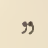 \\
\hline 3:dje & " & & . & 6,0 & $\eta$ & $\%$ & $"$ \\
\hline 4:de & 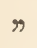 & & . & 2,0 & " & $\%$ & " \\
\hline 5:te & " & (den & längsta) & 2,0 & " & längre & $\%$ \\
\hline 6:te & $\eta$ & & . . . & 7,0 & $\pi$ & " & " \\
\hline
\end{tabular}

Garrulus glandarius L. - (ㅇ, Kantua 18740.)

1:sta handpennan . . 41,0 m.m. kortare än den 2:dra.

\begin{tabular}{|c|c|c|c|c|}
\hline 2:dra & $"$ & . . . & 20 & $m$ \\
\hline 3:dje & $\eta$ & . & 7 & $r$ \\
\hline :de & $"$ & . . & 3, & $\pi$ \\
\hline :te & $\%$ (den & längsta & 5, & längre \\
\hline & 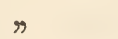 &.. & 9 & $m$ \\
\hline
\end{tabular}

Jemför man de första handpennornas inbördes längd med hvarandra, kan man finna, att vingarna åtminstone hos de fyra första arterna blifva ungefär i samma förhållande längre och spetsigare, som de respektiva flygttalen äro större.

En jemförelse af förhållandet i detta afseende emellan den 4:de och 5:te arten är deremot betydligt svårare, och detta gäller $\mathrm{i}$ allmänhet om de foglar, hos hvilka den 5:te eller 6:te handpennan är den längsta. Äfven inom sådana grupper, der skilnaden emellan handpennornas längd är mycket liten, såsom fallet är hos flere Passeres, är det nä- 
stan omöjligt att på detta sätt med någon säkerhet bedömma den relativa flygförmågan hos skilda arter.

Det är bekant att flere species, som hafva en djupt utskuren stjert, kunna under flygten göra mycket hastiga vändningar, en omständighet, som åtminstone vid en lika flygförmåga i öfrigt måhända förtjenar tagas $\mathrm{i}$ betraktande.

I det föregående hafva vi närmare skärskådat eller åtminstone antydt de förhållanden $\mathrm{i}$ foglarnas organiska byggnad, som kunna läggas till grund för bedömmandet af de mer eller mindre gynsamma anlagen för en utmärkt flygt. Stöder man den systematiska uppställningen af fogelarterna inom hvarje slägte och grupp på den relativa flygförmågan och använder för uppskattandet af densamma de methoder vi i sådant afseende föreslagit, våga vi tro att man, så ofullständiga dessa methoder tills vidare än äro, härigenom skall vinna åtminstone en förnuftig grund för denna uppställning, någonting som man hittills saknat, samt sålunda frigöra sig från det hittills rådande godtycket. Äfven inom andra djurklasser kunde lokomotionsorganernas utbildning ungefär på enahanda sätt uppskattas för att läggas till grund för bestämmandet af arternas inbördes företräde inom systemet. 


$$
\begin{gathered}
P B-\overrightarrow{8}-2 E-S B \\
E T
\end{gathered}
$$






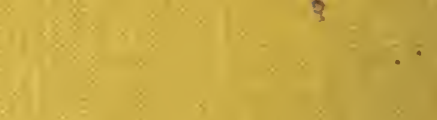

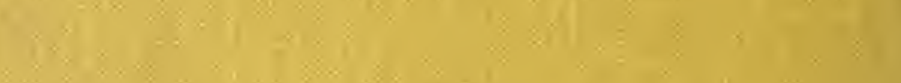

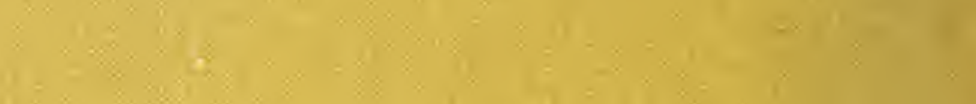

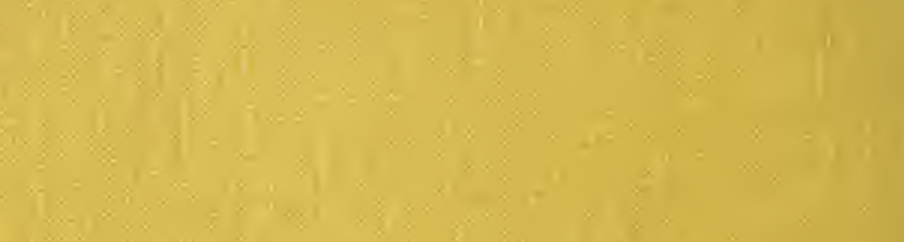

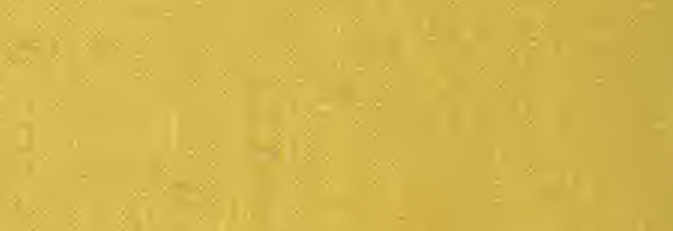

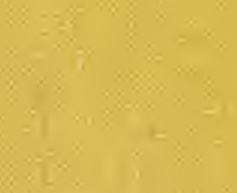

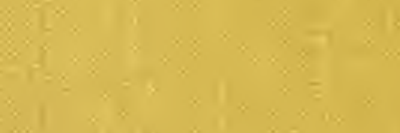

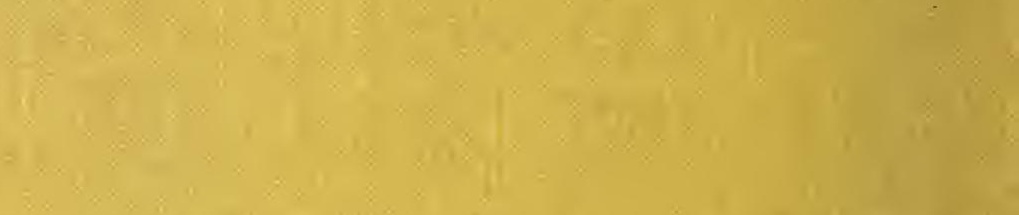

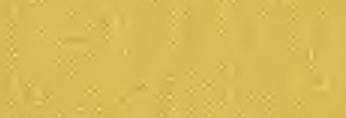$$
\text { (1) }
$$$$
y^{2}=x+2 x
$$$$
y^{x} x
$$$$
x=8
$$ 